\title{
A Sequential Electron Microscopic Healing Study of Grafted Palatal Mucosa
}

Robert Alan Weinstein

Loyola University Chicago

Follow this and additional works at: https://ecommons.luc.edu/luc_theses

\section{Recommended Citation}

Weinstein, Robert Alan, "A Sequential Electron Microscopic Healing Study of Grafted Palatal Mucosa" (1973). Master's Theses. 2647.

https://ecommons.luc.edu/luc_theses/2647

This Thesis is brought to you for free and open access by the Theses and Dissertations at Loyola eCommons. It has been accepted for inclusion in Master's Theses by an authorized administrator of Loyola eCommons. For more information, please contact ecommons@luc.edu. (c) $($ ) $\Theta \Theta$

This work is licensed under a Creative Commons Attribution-Noncommercial-No Derivative Works 3.0 License. Copyright @ 1973 Robert Alan Weinstein 


\title{
A SEQUEMTIAL EIECTRON MICROSCOPIC REALINO STUDX OP GRAFTED PAIATAL MUCOSA
}

\author{
BY \\ ROBERT AIAN WEINSTEIN D.D.S,
}

A THES IS SUBMITTED TO THE FACULIT OP THE GRADUATE SCHOOL OF LOYOLA UAIVERS ITY IN PARTLAL FOLFILIUENT OF THS REQUTREMENES FOR THE DEGREBE OF MASTER OF SCTENCE

\section{MAY}

1973 


\section{ACKNOWLEDGEHENTS}

I wish to express my deep gratitude to Dr, Allela Rubinste in whose contlnued guldance throughout the course of this project has enabled a better understanding and fuller approciation of research techniques and application, I would also 11ke to thank the other members of my advisory committee Dr. Nicholas Choukas and Dr. Charles Siraki, for their helprul suggestions and constructive critlcisms.

I would particularly like to thank 3rs. Prapuolenis for her excellent preparation of electron microscopic sections.

Finally, my brother steve deserves special thanks, 
DEDTCATIOH

to my wie carolym

Whout whese lastine patience and understanding. I know this work would not have cone to be 
TAELE OF CONTENTS

Chanter

Eace

I Introduction.................. 1

II Revlew of the Ilterature.......... 2

III Materisis and Wethods........... 31

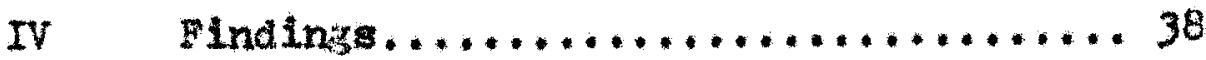

y Dlscussion....................63

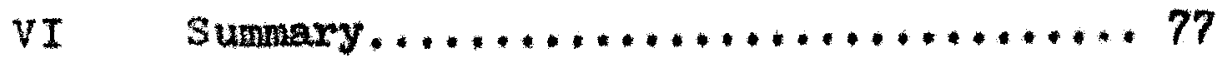

VII Concluslors................. 75

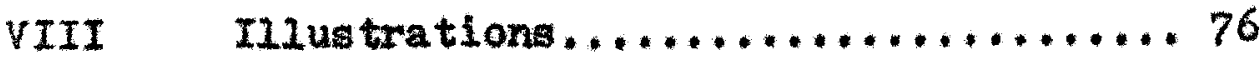

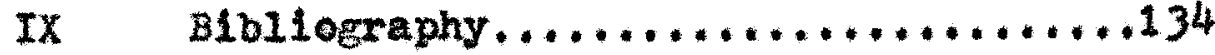


CHAPTER I

INTRODUCFION

The preservation of a wide variety of tissues by freezing and storage at low temperatures for subsequent use in surgical procedures has been used extensively in recent years. It has been ropeatedy observed, through various techniques, that damage does in fact occur to tissues by the freezine. Elycerolization and thawing processes themselvea. This tissue injury is reversible, however, as proven by its viability after various types of transplant procedures.

It is the purpose of this study to demonstrate first a technique for successfully freezing and storing human palatal mucosa. Subsequently, ultrastructural changes that occur in the glycerolized, frozen and thawed mucosa will be examined. Finally, a sequential electron microm scopic healing study will be performed to determine histologic changes in the palatal tissue autografts. A concomitant light microscopic healing survey of the same tissue will be used for supplemental comparisons. 


\section{CHAPTER II}

\section{REVIEW OF THE LITERATURE}

\section{A) Clinical characteristics of Palatal Hucosa:}

The palatal mucosa and gingiva have been classified by orban and sicher ${ }^{1}$ as masticatory mucosa. This is differentlated from lining and specialized oral mucosa on the basis of clinical and histological differences. Hasticatory mucosa is generally coral pink in color and tightly fixed to the underlying periosteun and therefore immovable. The palatal epithelium is uniform in character throughout and exhibits a thick keratinized layer. orban ${ }^{2}$ and Iund 3 describe four distinguishable regions of the hard palate accordine to the structure of the submucous layer. The first consists of the gingival region adjacent to the teeth and alveolar processes. The second region is similar histologically and consists of the palatine raphe. This area lies in the midine and extends from incisive papilla to soft palate. The anterolateral area or fatty zone is the third region and lies between the median raphe and ginglva. Finally, there is the posterolateral or glandular zone which also lies between the median raphe and ginglva. Posterior to this zone lies the soft palate. The anterior palate is characterized by the presence 
of live or six transverse folds or pal atine rugae. These may vary in number and prominence. Although palatal tissue is normally pink in color, different shades may exist due to variable melanin pigmentation. In addition, Dumnett ${ }^{4}$ feels the color may vary with the degree of epithellal cornification, the depth of epithelialization, and the degree of vascularity.

\section{B) Ultrastructure and Histology of Palatal Mucosa:}

The entire palate is covered by stratified squamous epithelium. Varying degrees of keratinization may exist in different areas of the palate. Four distinct layers of epithelium can be distinguished.

\section{Stratum basale}

The stratum basale or basal cell layer consists of low columnar cells with elongated nuclei that lie perpendicular to the basal surface of the epithelial tissue. The undulant double membrane which enclosea the nucleus is perforated by numerous pores. Outside the nucleus the cytoplasm contains different inclusions. Mitochondria are dispersed throughout the cytoplasm but seem to be more numerous in the immediate perinuelear region. 5.6 characteristic rough surfaced endoplasmic reticulum is well developed, but sparse as compared with the large number of free ribosones present throughout the cytoplasm. 6.7 
The Colgi appartus is also well developed and usually evident at opposite poles to the nucleus." Iipid vacuoles, various types of vesicles, glycogen granules and melanosones are interspersed between loosely woven bundles of tonoflaments throughout the cytoplasm. 5.9 These bundles of tonofilaments or tonofibrils cross the cytoplasm in varfous directions and are randomly arranged. They often are seen connecting with the attachment plaques of the desnosomes and sometimes change directions perpendicularly close to these attachment plaques, 5.7 Charles and smiddy ${ }^{10}$ postulate that the tonofilaments course from one desmosome to another within the cell.

The intercollular spaces are rather wide and clearly seen even at low magnification. The intercellular material filling these spaces is probably of a mucopolysaccharide nature and obviously plays a role in intercellular adhesion. The epithelium, however, is not a rigid assembly of units but a population of cells capable of independent aigration. The function of this intercellular naterial as a lubricant in facilitating the sliding of cells past one another has been suggested. The cell peripheries have cytoplasmic processes of different sizes and shapes which requently interdigitate. 7.12 Desmosones have a rather even distribution around the cells. The structure of desmosomes has become mell known. They consist of lamellar 
structures which parallel adjacent cell membranes. Tonofilaments converge lipon the attachment plaques which back the inner leaflet of the cell membrane. Between these attachment plaques are four paraliel layers of low electron density. These are separated by three more osmiophilic layers which present themselves as two lateral dense lines and a central dense 1ine.5,6.11,12 This central zone is felt to be the intercellular contact layer. ${ }^{12}$ Additional attachment devices consisting of hemidesmosomes, tight junctions (zonula occludens), and intermediate junctions (zonula adherence) are also frequently observed. Dense thickenings which occur at intervals in the dermal portion of the basal cell membrane are termed hemidesmosomes. These devices have alternating light and dense zones, with no adjacent counterpart in the lamina densa. The tight junctions in the stratum basale are usually short and follow a straight or slightly wavy course. This junctional complex is one in which the outer membrane leaflets of adjoining cells come together and fuse. ${ }^{22}$ Farquhar and Palade ${ }^{14}$ guggest these areas, in addition to representing attachment devices, influence diffusion conditions of the intercellular spaces and facilitate ion exchange between adjoining cells. Intermediate junctions consist of strict parallelism of adjoining cell membranes 
with a constant intercellular space (approx. 200\%). and nay span 0.2 microns in length. 15 Their function is obscure, but it is possible they may represent temporary interceliular attachment zones.

The basal epithelial cel.13 are frequently interrupted by so-called clear ce11s. Tho intercellular space between the clear cell and basal cell is narrow (200-300R) and lacks both desmosomes and tight junctions.? the only attachment devices are of the intermediate type. shere are no tonofilaments in the cytoplasm and the chromatin rich nucleus has deep infoldings.? Many small vesicles premelanosomes, and melanosones represent much of the cytoplasmic contents. zelickson ${ }^{6}$ states these cells produce melarin which they impart to the surrounding epithelial cells.

\section{3tratum aningaum}

The stratum spinosum iles above the basal cell layer and is several cell Layers thick. The cells nearest the basal cell layer are polyhedraz in shape. The colls ay proaching the stratum granulosun are more flattened and elongated. In contrast to the basal cells, the plasma membrane of the apinous cella is richly applied with des nosomes and numerous titht and internediate junet1ons. 5 The intercellular spaces are as wide or even wider than those observed in the stratum basale, with frequent inter- 
digitation of eytoplasmic projections.

The nuclei are generally round and exhibit nore infolding than those in the basal layer-especially as the cella migrate toward the surface. ${ }^{16}$ monofibrils are abundant and distributed much more uniformly than in the basal celis.7.16 ponofilaments similarly attach to desmosomes. Perinuclear zones are generally free of these filaments. as it is here that the cell organelles are found. In this area, large vesicles and endoplasmic reticulum are present in a random distribution. There are numerous ribosomes throughout the cytoplasm. Nitochondria are also most abundart in these perinuclear regions. The Golgi apparatus is not clearly definea. 6

Frojections of clear cells are seen interspersed between the epithelial celis and have similar characteristice as described for those in the basal layer. Hature melanin granules, however, cannot be identified with certainty. ${ }^{16}$ Thilander ${ }^{7}$ frequently found numerous rod-shaped bodles in these cells, they have a striated appearance and in some instances seem to be continuous with a vesicle or the endoplasmic reticulum. No function has been determined for these bodies.

The spinous cells nearest the stratum granulosum contain distinctive granules different from other celiular inclusions. They appear throughout the cytoplasm but are 
most numerous near the distal cell surface. Fithiof and Nersal1 17 describe these granular type bodies as being ovoid or rounded in section, and designate them "membranecoating granules." Wore recently they have been designated "microgranules." 11 under high magnification these granules have a highly ordered structure bound by a limiting membrane. 18 A lamellar structure is seen with parallel dense layers separated by a lighter zone. Their function is not known but it has been postulated they are of mitochondrial origin. 17

\section{Stratum granulosum}

The cells of the stratum eranulosum continue the process of hlattening begun in the stratum spinosum. At the most distal aspect they are alnost as flat as keratinized cells, with their axes parallel to the surface. Tonofilanente are numerous throughout the cell, especialiy in the jecper levels, but they are not as distinot as they were in the two lower layers. 6 hemorane-coating granules, identical to those in the distal spinous layer, becone nore prevalent in the gtratum granulosum. ${ }^{18}$ In the cells beneath the stratum comeur, they car be seen in close association with infolatings of the cell membrane and sonetimes in the axtracellular space. 18

the most alstinguishing feature of this layer are the 
keratohyaline granules it contains. These are electron dense, irregularly shaped granules which display no internal structures or evidence of any bounding membrane. ${ }^{11}$ Their number and size vary considerably from cell to cell. They often are closely associated with tonofibrils, frequently forming where two or more tonofibrils merge. 6.7 An intimate association of these granules with ribosomes has also been described. ${ }^{11}$ As the upper level of cells is approached, the keratohyaline granules become more numerous, while the cell nucleus and organelles seemingly distingrate. This is true of mitochondria, endoplasmic reticulum, free ribosomes, and identifiable tonofilaments. 6 Vacuolization is common to the upper level of these cells with disintegration of nuclei and organelles.?

As compared with the stratum spinosum the intercellular spaces are narrower, but attachment devices such as desmosomes, tight and intermediate junctions, are more plentiful. ${ }^{6}$ At the junction of granular cell plasma membranes with stratum comeum, the attachments appear thicker and more dense. Here the structure of desmosones change and they show a composite structure.?

\section{Straturn corneum}

The stratum corneum is composed of plat elongated cells oriented parallel to the epithelial surface. In 
palatal mucosa, this layer is usually five to elght cells thick. These cells are sharply demarcated from those of lower layers, as the transition is quite abrupt. The cells appear shrunken, flattened out, and are primarily composed of densely packed filaments in an osmiophilic, amorphous substance. 7 oval vacuoles are randomly dispersed throughout the cytoplasm. No discernible organelles are present. The Intercellular space is very narrow and follows a more Iinear pattern, parallel to the surface, than in the deeper epithelium. Desmosomes and tight junctions occur at short intervals. but have a modifled structure. The plasma membrames are thick with no discernible attachment plaques in areas of desmosomal formation. The cytoplasm subjacent to these nodifled desmosomes sometimes shows a small concentration of dense amorphous material. 12 In the lower stratum corneum, where cell borders are more distinct, striated intercellular material can be seen in continuity with the dense intercellular part of the modified desmosomes. ${ }^{18}$ This material is similar in appearance to the membrane-coating granules found intracellularly in both stratum spinosum and stratum granulosum. Occasionally, the intercellular spaces at the tissue surface are closed by a modified desmosome or tight junction. 7.12 In other instances, the uppermost cornified cells appear to separate from noighboring 
cel1s by rupture of the desmosomes. 5

\section{The en thelio-connective tissue junction}

The palatal epithelium is separated from the underlying connective tissue by a basal lamina. This structure is 400-700\% thick and consiste primarily of a finely granular or sometimes filamentous substance.7 It is undulating in nature, following the numerous invaginations of connective tissue into the overlying epithelial layer. Interposed between this osmiophilic basal lamina and the cell membranes of the basal cells is a clear homogenous zone $300-500 \AA$ in width which has been named the lamina lucida. ${ }^{12}$ It is filled with fine filaments and a diffuse substance which may be a cementing substance. 19 This zone is interrupted at irregular intervals by fllamentous structures extending from hemidesmosomes on the basal cell membranes to the lamina densa. 5 The henidesmosomes are about 2008 thick and consist of attachment plaques on the basal cell membrane with a peripheral density in the lamina lucida, appearing as an osmiophilic line. This line in the lamina lucida is located 200$250 \AA$ from the attachment plaque and gives the area a lamellar appearance. 12

Immediately below the lamina densa, Meyer ${ }^{11}$ describes a scalloped network of densely staining fibrils, 200-4008 In diameter. These flbrils display a bending pattern. 
though without regular repeating units as seen in collagen. As these "anchoring fibrils" approach the basal lamina, they branch into smaller groups of filaments ( $20 \AA$ in diameter) which fan out into a spray. These filaments then enter the basal lamina and appear to contribute to its filamentous network. Some filaments seem to traverse the basal lamina and the lamina lucida, reaching the plasma membrane of the basal cell. This relationship is more pronounced at the sites of hemidesmosomes.

On the connective tissue side of the basal lamina, the anchoring fibrils are in intimate relationship with collagen fibers of the lamina propria. Collagen fibers running toward epithelium take on a course parallel to the basal lamina, passing through spaces or tunnels formed by the anchoring fibrils. 11

The epithelio-connective tissue junction with attachment devices and undulating pattern, is an adaptation to provide a better nechanical bond between epithelium and connective tissue in areas of stress. Meyer and Gerson 20 claim that structural features of palatal mucosa equip this tissue to resist mechanical forces. Thilander and $\mathrm{Bloom}{ }^{12}$ state that the number and position of these attachment devices, coupled with the degree of keratinization, determine how effectively the mucosa can resist penetration of different substances from the tissue surface. 


\section{Submocosa and connective tissue}

The structural aspects of connective tissue and submucosa vary in different areas of the hard palate. The marginal areas and median palatine raphe are zones in which the submucosal layer cannot be differentiated from the Iamina propria or perlosteum. 2 In these areas, fibrous bands of collagen bundles run at right angles to the surface epithelfum, fixing lamina propria directly to periosteum. In the paired areas between palatine raphe and palatine gingiva, these bands become separated by a distinct submucosal layer. Fat lobules are packed into the spaces in the anterolateral zones, whereas minor sallvary glands occupy the posterior aspects. Sicher 21 states that the fat and glands provide a resilient cushion for wide aroas or the palatine mucosa. Schour ${ }^{22}$ describes the function of this cushion as to distribute local pressures over a wider area in the same manner as the skin over the palms and soles.

Numerous cells of different function and structure are interspersed between intercellular substances and Plbrillar elements. These cells, including fibroblasts, histlocytes, mobile macrophages, mast cells, lymphocytes, neutrophlls, and plasma cells, will vary in occurence and appearance in different areas of the palate. The fibroblast 
is the principal structural cell of the lamina propria and warrants more detailed discussion. It is the most frequently found cell and carries out the major cellular functions of the tissue. It is an elongated or star-shaped cell having long cytoplasmic processes, and its nucleus senerally contains a prominent nucleolus. It is most frequently observed In close association with surrounding collagen bundles. Ultrastructural features reveal numerous mitochondria, a well marked Golgi complex, large amounts of granular endoplasmic reticulum and free ribosomes.

The fibroblast is believed to be the connective tissue cell responsible for biosynthesis of collagen ground substance, mucopolysaccharides, and elastin, and its organelles provide the morphologic framework for the symthesis, aggregation, and secretion of these substances, 23

A voluminous mass of loose connective tissue is interposed between perlosteum and submucosa proper in the posterolateral hard palate. This tissue contains the anterior branches of palatine nerves and the greater palatine artery which exits the najor palatine foramen in this area. 21,24

\section{C) Intraoral arafting:}

The first reported grafting procedures in order to establish an increased buccal sulcus in the mandibular vestibule were performed by Moskowicz ${ }^{25}$ in 1916 and Esser 26 
in 1917. In this technique, an extre-oral pocket was formed in the submental region and a skin graft molded around a dental compound stent was inserted. About ten days later. an incision was made on top of the stent so it could be removed intraorally. This procedure created a skin-lined pouch that constituted the new labial sulcus. Within a few years this technique was improved by Plckerill, 27 utilizing entirely an intraoral approach. Gillies, 28 Waldran. 29 and ${ }^{\prime}$ iner and Jackson ${ }^{30}$ also used this technique in cases of Insufflcient labial sulcus in the maxilla. Various other grafting techniques have been reported since this time for extension of atrophic edentulous ridges in order to provide better denture retention. 31.32 .33

It was not until 1964 that Propper ${ }^{34}$ utilized tissue from an intraoral site for a sinilar procedure obviating the necessity of creating a wound in another area of the patient's body. In 1967, Goldberg ${ }^{35}$ pointed out the advantages of mucosal grafts for vestibuloplastys 1) a.1. surgery is intz-oral, 2) scar formation is minimal. 3) the grafted tissue wl11 oushion the dentures, and 4) healing time is shortened and discomfort minimized. In 1968, Sullivan and Atkins ${ }^{36}$ elaborated on the principles of a successful "take" of erafted oral mucosa, 1) hemostasis of the reciplent bed, 2) intial pressure to establish circulation, and 3) inmobilization of the graft. 
The healing procesa of eplit thickness akin gratts has boen divided into two phases by clemanezan. 37.38 the first phase consists of plasmatic clroulation which takes place before the blood supply id restored. The vesaels of the free graft are filled wh pluid from the reciplent bed by mydrostatic dmamies (canillary action). This oarly plagnatic elreulation provents the drying of the craft and kepes the versels open, permltting comunicatlons fram the uncurlytro ressels to be established. The plassatic phese angugs for about the first 48 hours after eraft placement. The second phese betins with evidence of som blood flow into the grafted tissue. At the end of 4 or 5 days, blood fiow is establiehed in all vestele. ${ }^{38}$ sequential houling etuales of free finglval grafts by Garetulo and Arroeha 39 conflrmed these stndines, Under 11ght wloroseopy, they found that sequentlal blopstes of the tranaplanted tiseus devonstrated continued incorparation of the graft into the auryound in tissue, th tho concomitant loss of auper flestepl the llal colle。

Korran'g work Involving a light wioroseople hoaling study of frozon, thawed and grafted oral mucosa, revealed clelayed regeneration of the grattad tasue, especlally in the nore superpiclal ept thellal layers. Thls delay in regent eration was attributed to oryoinfury frow treesing, thewing and glycerolization of the muesal tieeue. Maloney et al $1^{41}$ 
reported the absence of inflanmatory changes in canine tucosal grofts after 17 daye. Thirty day biopsles from several histologic studies of grafted oral mucosa have shown the graft to be indistinguishable from the surroundins mature tissue. $39,40,42$

\section{D) Ereservation of Eoithelial Hissue:}

The preservation of epithelial tissue by cold atorage has been reported as early as 1903 . by Wentscher. 43 he used refrigerated free skin as autografta on laboratory animals as autografts. Successful transplantation was accomplished after refrigeration $\left(0^{\circ}-4^{\circ} \mathrm{C}\right.$.) from 7 to 14 days. This idea was elaborated upon by carre1, 44 who successfully transplanted various animal tissues after they had been stored by refrigeration $\left(-1^{\circ} \mathrm{C}\right.$. to $+7^{\circ} \mathrm{C}$ ) for periods ranging from 1 day to 11 months. He concluded that vaseline was the nost satisfactory media for preserving these grafts under refrigeration.

Deliberate refrigeration of skin removed at elective operations for later clinlcal use was performed by brown and McDowe $11^{45}$ in 1943. They reported the case of a successful full-thickness eraft on the neck, previously stored in an icemox at $3^{\circ}$ to $5^{\circ} \mathrm{C}$. for 48 hours. More extensive use and refinement of technique was presented one year later by Webster. 46 He reported success with autogenous 
transplantation of skin stored up to 21 days at $4^{\circ} \mathrm{C}$.

The concept that skin might be frozen and thawed in vitro to becoine functional as a transplant was suggested by the work of Mider and horton. 47 They utilized rat skin as control material for freezing experiments with tumors. Wethyl cellosolve-carbon dioxide mixtures were used for both rapid $(3-5 \mathrm{~min}$,$) and slow (20 min.) freezing to -74^{\circ} \mathrm{C}$. Thawing was done either at room temperature, $20^{\circ} \mathrm{C}$. or in a water bath at $30^{\circ} \mathrm{C} .$. and took $8-12 \mathrm{~min}$. The thawed tissue was then inoculated allogeneically into the subcutaneous tissue of adult rats. Light microscopic preparations of the grafted tissue at ten days revealed mitotic figures among the epithelial cells, which along with the general appearance of the tissue, indicated viablifty. Less evidence of cellular damage was seen in the skin grafts that were frozen slowly.

Briggs and Jund ${ }^{48}$ clalmed that the experiments of Mider and horton were inconclusive, that frozen and thawed skin remained functional, since no skin grafts proper were made. They developed methods of obtaining, freezing. thawing, and autogenelcally transplanting mouse skin with success. They concluded that slow freezing (15-35 min.) to $-78.5^{\circ} \mathrm{C}$. with rapid thawing $(1-2 \mathrm{~min}$. $)$ to $30^{\circ} \mathrm{C}$. gave the best results. The poztulation was made that the "bound" 
water content of the cells might have accounted for the reduction of the ice crystal formation that is known to cause irreversible damage during rreezing.

In 1945. Strumia and Hodge 49 reported $80.5 \%$ take of autogenous frozen and thawed split thickness gkin grafts as compared with $86.4 \%$ takes of fresh skin in the same patientg. Their freezing techniques were based on previous experimental work on the preservation of plasme in the frozen state. It was found that under conditions of rapid freezing, maintenance at a temperature below $-15^{\circ} \mathrm{C}$. and rapla thawing, followed by warming to $37^{\circ} \mathrm{C}$. all the physicochemical properties of complex colloids were retained. Instantaneous freezing at very low temperatures was not felt to be essential. Their results did not appear to be affected by the time of storage of the grafts, which ranged from one to sixty-one days.

Billingham and hedawar 50 investizated frozen and thawed rabbit skin with two objectives in mind 1) to determine those conditions of freezing and thawing that result in the least possible damage to the various cellular and fibrous constituents of sking and 2) to determine the degree to which skin will withstand dehydration in the frozen state. Their methods involved the use of thin copper strips to which the split thlckness skin grafts 
adhered to with vaseline. Qufck freezing was achieved by plunging the copper carrier with graft below the surface of an isopentane bath chilled in liquid air to a temperature below $-150^{\circ} \mathrm{C}$. Slow freezing involved placing the copper strip with graft in a bath at $-79^{\circ} \mathrm{C}$. for 15 minutes. and then transferring it to a bath at $-150^{\circ} \mathrm{C}$. for 15 minutes more. Quick thawing was achieved by plunging the metal graft-carrier bearing the frozen grafts directly into $37^{\circ} \mathrm{C}$. Ringer's solution. Slow thawing took 5 minutes in a cold air chamber surrounded by crushed ice.

Prior to being subjected to the slow or rapid freezing procedure, the grafts were soaked for one hour at room temperature in either Ringex's solution or in a $15 \mathrm{w} / \mathrm{w}$ solution of glycerol following the lead of Polge. Smith. and Parkes. 51 who found that glycerol protected fow 1 spermatozoa from otherwise fatal effects of vitrification or "snap freezing".

The clinical assessment upon which Billingham and Medawar. 50 and later Billingham ${ }^{52}$ determined how well rabbit skin was able to resist their freezing procedures was based on the rate of growth of the transplanted graft. Its degree of pigmentation. the normality of its crop of hairs, the survival of sebaceous slands, and restored integrity of the fine structure of the collagenous endoskelton of the graft. 
Their findings were sumnarized as follows! 1) rabbit ear skin can withetand either rapid or slow freezing dow to the temperature of liquid air, 2) slow freezing gives better preservation than rapid freezing, but impregnation with glycerol abates some of the harmful consequences of rapid freezing. Epidermal melanoblasts do not withstand rapid freezing unless first protected by glycerol, 3) rapid thawing gives better preservation than slow thawlng, and 4) skin slowly frozen to $-79^{\circ} \mathrm{C}$. , after impregnation with glycerol solution and stored for four months was indstinguishable, on transplantation from a freshly removed graft. 5 mith, 53 from extensive experimental work dating back to 1949 , elaborated upon the cryoprotective agent glycerol used in appropriate concentrations for the preservation of tissues at low temperatures. It was an accidental discovery when Polge, et al. 51 in 1949, found that glycerol had the renarkable property of protecting the spermatozoa of the domestic cock against the otherwise fatal effects of freezing and thawing. This discovery, in addition to investigations carried out on mammalian tissues by Blllingham and Sedawar, 50 and Blumenthal and Walsh, 54 indicated that with the aid of glycerol a wide variety of cells and tissues could be preserved for long periods of time at low temperatures for future use in various aspects of medicine. 
Work done by Rubinstein and Trobaugh 55 describes a technique for preservation of hematopoietic tissue. In addition, the histologic changes in the frozen and thawed tissue at the ultrastructural level is described.

The flrst reported work done on frozen oral mucosa was that of cogsins and cibson 56 in 1968. Human gingival tissues obtained at the time of periodontal surgery were fragmented and suspended in a balanced salt solution containing $7.5 \%$ dimethylsulfoxide, a cryoprotective agent. A slow freeze was then instituted at a rate of $1^{\circ} \mathrm{C} . / \mathrm{min}$. to $-30^{\circ} \mathrm{C}$. , and then at $10^{\circ} \mathrm{C} . / \mathrm{min}$, to $-150^{\circ} \mathrm{C}$. It was stored at $-150^{\circ} \mathrm{C}$. for fourteen months. Utilizing a quick thaw (1-2 min.), they were able to grow these gingival cells in tissue culture. Cell migration was evident within seven days in culture and generally a monolayer of epithelial-1lke cells was clearly demonstrated by the tenth day. Enzyme histochemical studies were carried out on other fragments that were refrozen on dry ice. Inzyme activity was clearly demonstrated for individual dehydrogenases, acid and alkaline phosphateses, as woll as non-specific esterases. In general, the oxidative enzymes showed Ereatest activity in the deeper layers of epithelium with decreasing activity toward the surface. The histochemical demonstration of active enzymes in the tissues after torage 
would presuppose that they were present before freezing and therefore could not be construed to be a test for viability in, and by, itself. On the other hand, complete loss of enzyme activity could indicate loss of viablifty. xoman, 40 in 1972, studled clinical and histolosic receneration of frozen and thawed human oral mucosa used as autogenous grafts for periodontal procedures. The tissues were placed in ampules contalning Hank's balanced salt solution with $12 \%$ Elycerol, and a slow freeze initiated at the rate of $2^{\circ} \mathrm{c} . \mathrm{min}$. to $-100^{\circ} \mathrm{C}$. . The freezing ampules were then transferred immediately to liquid nitrogen $\left(-196^{\circ} \mathrm{C},\right)$ and stored for three days.

Rapid thawine (1-2 nin.) was accomplished by plunging the ampules into a $40^{\circ} \mathrm{C}$. water bath. After deglycerolization and eraftine procedures, biopsies were taken at speciried intervels to evaluate the regeneration under the light mieroscope. Sequentiel biopsles of the grafted tissues showed similar patterns of regeneration studied by other workers 57 on fresh ginglval grafts. However, a zetarded lack of maturation in epitheliun and connective tiseve was noted, especially in the earlier apecimens. The more obvious deviations were seen in the superficial eplthelial cells, whlle besal cell and connective tissue progressed similarly to that of nomal controls. A con- 
clusion was made that freezing and thawing of glycerolized gingiva apparently accounted for the deviations from normal. seen by sequential histologic examination.

\section{E) Gryoliniury:}

Significant abatement in cellular damage by freezing has been attained since 1949 when Polge. Snith and Farises 51 discovered that living cells could be frozen and thawed without harm if glycerol was introduced into their suspending medium. This glycol is a water binder as one mole of slycerol ties up three moles of water. Many other cryoprotective agents. including other glycols and various sugars, are also effective water binders, but glycerol is still widely favored because of its relative nontoxicity in moderate concentrations and relative ease with which it passes through most cell membranes. ${ }^{58}$ The $5-15 \%$ concentration that is generally used does not prevent all ice from forming. but it does serve to reduce the concentration of solutes and rate of ice crystallization to a tolerable degree. 58 In his work with humen erythrocytes, Lovelock 59 proposes that the buffer effect of including glycerol in the suspending mediun is to reduce the range of eritical temperatures in which damage takes place. He proposes a colligative mechanism of protection whereby the presence of glycerol in the suspending medium lowers the concentration 
of salt in equilibrium with lce at any temperature below freezing, when the elycerol is able to penetrate the cells, this also applies to the natural salts inside them. If enough glycerol is present, the salt concentration does not rise to a critically damaging level until the temperature is so low that the rate of damage is also low enough to be tolerable.

Meryman 60 cltes that many cryoprotective compounds are known to penetrate the cells which they protect, while other compounds can enter cells without apparent damage at room temperature. However, after freezing and thawing. with temperature rises and progressive separation of ice. the latter compounds provide little cryoprotection due to their lack of affinlty for water. The most important characteristics of solutes that protect living cells from freeaing temperatures is most probably affinity for water. Ease of penetration is another important factor.

Most cells live in contact with a dilute aqueous medfum, both intra- and extracellularly. Water is the solvent for suspended solutes such as proteins, liptds, salts, hydrogen 10ns, and other substances. The effects of freezing are transmitted to the cell through this medium. 58 When living cells are frozen, the transition of water to ice provides increased concentration of these dissolved 
substances in the remaining 11quid. It is this increased concentration of intracellular components that is deleterfous to the cell and often causes irreversible damage. A number of mechanisms have been described to explain in jury to living cells after freezing and storage at low temperatures. Lovelock, with specific reference to arythrocytes, proposes that it is the concentration of salt resulting from the freezing out of water that produces hemolysis. He demonstrated that whenever the extraceliular concentration exceeded $0.8 \% \mathrm{NaCl}$, hemolysis began, even when the relationship between salt concentration and freezing temperature was altered by the addition of cryoprotective agents.

Sovelock 59 further explains that the destructive action of exposure to concentrated salt solutions is not Instantaneous and the survival of rapidly frozen and thawed cells is attributed to this factor. He suggests salt concentration may cause damage in the form of a "Iyotropic" effect on the lipoprotein constituents of the cell membrane because of the cholesterol and phospholiplds appearance in the supernatant when exythrocytes are suspended in excessively high salt concentrations.

Dosbbler and Rinfret ${ }^{61}$ have shown through blochemical analysis that cells recovered physically intact after rapid 
freezing have altered electrolyte compostion. Total catiop concentration remains relatively unchanged, while sodium increases and potassium decreases. They suggest some enzyratic damage occurs in the cell membrane rendering the uavel cation transport processes ineffective. Meryman ${ }^{62}$ also studied freezing injury to red blood cells, and postulated the mechanism of seezing injury is due to osmotic stress rather than the toxic effects of increased salt concentrations. He concluded that suspension of cells in solutions of non-penetrating solutes (e.g. Naclp) of progressively increasing concentration creates a progressively increasing stress which is related to the osmotifc loss of cell liquid phase and associated cell volume reduction. At some limiting volume, the stress becomes sufficient to cause a sudden loss of membrane intersity and an influx of extracellular solution. The limiting stress is related to the proportion of cell liquid phase removed and not the absolute concentration or identity of the intraor extracellular solute (provided it is non-tozic). There is evidence for a progressive development of stress up to the critical level.

Neryman ${ }^{62}$ favors the hypothesis that the stress of hypertonic suspensions results from resistance of the cell to unrestrained reduction in volume. This failure of the 
cell to shrink freely results in an osmotic gradient across the cell menbrane with an inward osmotic gradient belanced by the mechanlcal resistance of the coll.

Physical damage to the cell by lce crystal formation, both win the cell and throughout its suspending medium. has been proposed by Mazur. 63 From his work involving the freezing of various microorganlsms at difforent rates, he Bugesests that doath is not the result of high concentrations of solutes. If it were, one would expect longer exposures to produce greater damace, but the reverse actually occurs. Slow cooling is less hamful than rapid cooline, even though slow cooling results in the longer exposure. Moreover, even with rapid cooling the damage occurs almost entirely with in the first minutes of exposure and does not increase signisicantly with time. He proposes the physical consequences of exposure to low temperatures that are reaponsible for cell death fall into two major categories: those derived from changes in $\mathrm{kin-}$ otic energy of molecules or temperature itself, and those dependent upon phase changes specifically the freezing of water and the meltine of ice.

steere ${ }^{64}$ used freeze-etching to study changes occurrine in the freezing of red blood cells, dog heart, and intestinal epithelium of monkeys. He found this technique 
particularly suitable for showing membrane disruption by fce crystal formation. The use of glycerol in increasing concentrations up to $40 \%$ revealed decreased damage to nembranes by decreasing the amount of ice crystal formation. He also noted that sometimes, even if severe damage occurred to a cell, there may be little apparent damage to cella immediately adjacent to the damaged ones.

Subsequent studies by hazur ${ }^{65}$ and lititvan ${ }^{66}$ attribute cryoinjury to differences in vapor pressure of water across the cell nembrane resulting from the supercooled intracellular water as the teaperature decreases. Each proposes an alternative mechanism by which this difference in vapor pressure attains equilfbrium. Both mechanisms suggest cellular damage in the form of protein denaturation.

Cell cryoinjury, manifested by ultrastructural and related functional alterations of mitochondria has been studied by Sherman, ${ }^{67}$ using mouse kidney. He considers injury to be induced directly by physical distortion, increased electrolyte concentration, or other events durine the formation and dissolution of 1ce. The proposition is made that freezing and thawine may elicit deleterious consequances indirectly through an initial effect on another organelle or group of organelles based on the ir 
inherent veriations in cryosensitivity, and thein interreIntionships in form and function.

Persidsky ${ }^{68}$ suggests that Iysosomes may play a crutis]. role in the mechanism of cell cryotnjury, due to their high gensitivity to environmental changes. A zysosome specific agent, trypan blue, was chosen for his experiments because of its known ability to concentrate selectively in lysosomes and to inhlbit their enzymes. This dye was injected into the bone narrow of rats before testinc the ability of the mannow to recover after cryopreservation. Based on incorporation of ${ }^{14}$-1 gycine, and prowth in tissue culture, bone marron cells from treated animals showed on the average, three times greater recovery than cells from untreated animals. It was conclured that the striking improvement in cell preservation resulted directly from the inhibition of lysosomal enzymes by trypan blue. Consequently, it may follow that activation of lysosomal enzymos by freezing and thawine can be a primary cause of cell cryoinjury. 


\section{CHAPTER III \\ BATERIALS AND NTHODS}

The ultrastructure of frozen and stored human palatal mucosa used as autogenous free graft material for nandibular vestibuloplasty was studied through the course of the healing process. Concomitant clinical and light microscopy evaluations were also per med. All meterials used in conjunction with any surgical procedure were sterilized and sterile surgical procedure was adhered to at all times,

\section{Erocurement of Iisoue}

Four edentulous patients presenting with atrophy of the mandibular anterlor alveolar ridge were selected (fig 1). Handibular vestibuloplasty with an autogenous graft was required as part of their total treatment plan. The procedures were thoroughly explained to all the participants and all were willing to be part of the study. vitten consents were signed in all cases. An identical procedure was carried out on all four patients.

At an appointed time, the patient was anesthetized by local infiltration of the anterior two-thirds of the hard palate. By supraperiosteal dissection, a horseshoe shaped strip of palatal tissue neasurine approximately 
$1 \mathrm{ch}$ in width by $4 \mathrm{~cm}$ in length was secured (fir 2 ). Two 2 rata $^{3}$ fragnents of tissue were taken from one end of the craft as fresh tiesue controls. One fragrnent was immedlateiy placed in cold 2.5 buffered glutaraldehyde for the electron microscopic study, while the other was placed in 10 formalin for subsequent evaluation by light microscopy. The remaining donor graft was then "de-fatted," and placed in a speoimen bottle containine cold hank's balanced salt solution. The patients maxillary prosthesis, lined with surgicel was placed for hernostasis.

2. We thods of freezing and whavine

Approximately 15 minutes after excision, the graft tissue to be frozen was renoved from the bottle containine pure Hank's solution and was immersed in a separate bottle containing $15 \mathrm{ml}$ of 12 solution of mlycerol in trank's balanced salt solution. The speciraen in the suspending mediun wasthen taken to another facility for the subeequent freezing procedure. **

The strip of praft and $5 \mathrm{ml}$ of its nedium were transm ferred to a freezing ampule approxinately one hour

4 Johns on s Johns on

* The freezing procedures were carried out at the section of Hematoloy, Dept. of Hedicine of Rush-presbyterian St. Lukes Medical Center, Chicaro, Illinois

* theaton lass Co. 
after the initial surgery. This ampule was sealed by tho flane of a propane torch and then placed in a Linde $3 \mathrm{H}-3^{*}$ liquid nitrogen freezing unit.

A separate ampule containing protective agents (standard proportion) and a fragment of nucosa was also placed in this unit. This ampule was atoppered with a sterile rubber vacutainer stopper, and a Saber Cu-constantan themocouple* was foroed through the stopper. One tip of the thermocouple was connected to an Electronil III Strip chart Recorder.***

The tissue was frozen to $-12^{\circ} \mathrm{C}$, at a rate of $2^{\circ} \mathrm{C} . / \mathrm{min}$. by flooding the cooling chamber of the freezing unit with vaporized nitrofen. Immediately after the release of the heat of fusion, the suspension was cooled to $-100^{\circ} \mathrm{C}$, at $2^{\circ} \mathrm{C} / \mathrm{min}$. The frozen ampules were immediately transferred to a liquid nitrogen tank $\left(-196^{\circ} \mathrm{O}\right.$.) where they were stored for one month.

One hour prior to transplantation, the frozen ampule was brought to Loyola University in a container filled with frozen $\mathrm{CO}_{2}\left(-79^{\circ} \mathrm{C}\right.$.). Immediately prior to the graft stace of the vestibuloplasty procedure, the ampule was irmersed in a $40^{\circ} \mathrm{C}$. water bath and thawed for $1-2$ minutes. 


\section{Desducerolization}

After thawing the ampule was sut open and its contents poured into a sterile $100 \mathrm{ml}$ beaker. Then, at two minute intervals, the following amounts of sterile $35 \%$ griucose and $6 \%$ dextran solutions were added to the beaker

$$
\begin{aligned}
& 2.5 \mathrm{cc} \text { glucose } \\
& 3.75 \mathrm{cc} \text { dextran } \\
& 11.25 \mathrm{cc} \text { dextran } \\
& 15 . \mathrm{cc} \text { dextran } \\
& 12.5 \mathrm{cc} \text { dextran }
\end{aligned}
$$

Two $2 \mathrm{~mm}^{3}$ sections were again sectioned from the strip eraft and fized for both electron and light microscopy as described previously. Following procurement of these biopsies, the graft was immediately transplanted to the reclpient bed.

4. Preparation of the Recinient Bed

A surgical technique similar to that described by Hall and 0. steen $^{69}$ was employed. With the patient under a running intravenous sedation, bilateral mandibular nerve block anesthesia with $2 \%$ xylocaine (conc. epinephrine 1:100,000) was given. In addition, the anesthetic solution was infiltrated into buccal, labial, and Iingual tissues, serving to "balloon" the tissues for ease of dissection and to provide hemostasis. A mucosal incision was then made on the buccal aspect of the alveolar crest, just anterior to the retromolar pad. This incision was 
extended along the junction of the loose and attached gingiva to the retromolar pad of the opposite side. A suprapertosteal alssection of buccal and labial tissue was then performed, stripping all muscle attachments, excepting the inferior-most attachment of mentalis muscle. Both mental nerves were exposed bilaterally and left intact. A similar supraperiosteal dissection was carried out in the anterior Iingual area with stripping of the superior belly of the genioglossus muscle. Lowering of the anterior eloor of the mouth was accomplished by placement of four evenly spaced catgut sutures placed through the free Ingual tissue, under the mandible and attachine to corresponding areas of the dissected free labial tissue marrins. The Iree labial and buccal tissue margins were then sutured to the periosteum at the most inferior aspect of the dissection (fig, 3 ).

\section{Elacement of the oraft}

A prefabrlcated clear acrylic splint (fig. 4), presoaked in clear merthiolate solution, was then filled with a soft periocontal dressin, and an impression of the surfical area was taken. ureen stick dental compound was used to extond the splint in the necessary areas. The graft was secured to the pelostevm with internittant oatrut sutures (fi. s). ith raft in place, the acrylic aplint 
with corrected Iinine and extension was then placed over the surglcal area and secured with two 25 pauge stainless steel circumandibular wires. The patients were discharged and placed on appopriate antiblotic and analgesic therapy.

\section{Dost-Operative Care and blopsy precedure}

Two small biopsies ( $2 \mathrm{~mm} \times 2 \mathrm{~mm} \times 2 \mathrm{~mm}$ ) of the graft during the healing stages were taken from each patient (i.e. patient 1 was blopsied at 0 and 12 days it 2 , at 2 and 15 days 3 , at 5 and 25 days, and 74 , at 9 and 30 days). The acrylic splint was not removed until one week post-op, and thus it was necessary to provide $a$ hole in the anterlor region of the splint (fie. 6) for obtaining blopsy t1ssue from patients 2 and 3 (the 2 and 5 day biopsies). These biopsies were excised with a fil berd Parker knife and AIIIs forceps.

\section{Erocessine Tissue for dectron Hicroscony}

All tissues to be examined under the electron microscope (fresh as well as frozen and thawed) were trimed into $1 \mathrm{~mm}^{3}$ fraements. These fragments were ixed in $2.5 \%$ buffered glutaraldehyde for at least one hour and postfixed in buffered $\mathrm{OsO}_{4}$ for 60 minutes. The tissues were then dehydrated in 70\%, 95\%, and 100, alcohols and propylene oxide (1-2 epoxypropane), respectively. Epon 812 
was used as the embeding medium. Whe tissue blocks were sectioned with a dianond knife attached to an IT-1 Forter plum Ultratome. The sections, 550-6508 in thichess, were ploked up in 300 mesh copper grids. They wore then stained with a gaturated solution of uranyl acetate for 3 minutes. washed in dist1lied water for one minute and post-gtained with $0.2 \%$ lead citrate for 3 minutes.

9. Eroceasine Tissue for Wicht Microscooy

The biopsles ( $2 \mathrm{~mm} \times 2 \mathrm{~mm} \times 2 \mathrm{~mm}$ ) to be prepared for light microscopy were immediately fixed in $10 \%$ formalin solution. They were then embedded in paraffin and sections of 7-10 microns in thickness were cut and stained with hematoxylin and oosin. 
CHAPTER IV

FINUTH

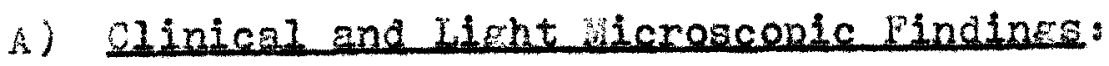

Due to technical difficulties, especially the size of the specimen, many of the biopsies (days 2, 5, 9, and 15) prepared for light microscopy did not show ept thelium upon examination. A previous sequential light microscopy healing study of frozen and thawed oral mucosal tissue, by Korman, ${ }^{40}$ will be utilized for the description of the above mentioned missing blopsies and subsecuent correlation with the light microscopic and ultrastructural changes observed in this healing study.

\section{Lere day post-frozen eraft}

Inmediately after thawing, the eraft was identical in appearance, texture, and consistency to the same fresh tissue (fig. 2).

A histologic section of the zero day post-frozen graft is seen in fig. 7. The section is cut tangentially, showine both epithelium and sose underlyine connective tissue. The epithelium shows generalized hydropic degeneration with notable perinuclear edema throughout all levels. The stratu granulosum shows an average thickness with typical keratohyaline granules. The least dernonstrable 
light aicroscopic changes are seen in the lower spinous and basal cells.

The basal lamina appears thicker than normal. The underlying connective tissue reveals well preserved fibroblasts, but collagen buidle formations are amorphous in appearance. Capillaries, devold of erythrocytes, are present in the connectiva tissue.

\section{Twe dav post-frozen araft}

Clinical assessment of the two day graft was difficult since the acrylic stabilization splint was still in place with only a small hole provided for obtaining a biopsy specimen (fig. 8). The graft, however, was fairly woll adherent to the recipient bed. It was shiny in appearance and white in color. Nreas of overlying necrotic tissue were evident and easily wiped away with a cotton tipped applicator.

Histologically, the stratum corneum is almost entirely absent. The cells of the stratum granulosum are pale in appearance with deficient uptake of the hematoxylin stain by their nuclei. The stratum spinosum and stratum basale have the same pale appearance (fig. 9). The basal lanina, although still amorphous in appearance, is disrupted throughout. Acute inflamatory cells can be seen in the connective tissue. The arorphous appearance of 
the collagen fibers persists, with fibroblasts interspersed throughout. 40

\section{Eive day post-froren graft}

Agein, adequate visualization of the graft tisaue at this stage was impaired due to the overlying acrylic stab1Iization splint. The donor tissue, however, was quite adherent to the reciplent bed. The graft remained shiny in appearance and white in color. Areas of necrosis were still evident, and at this stage, scattered areas of what appeared to be granulation tissue, red in color and nore bulbous in appearance, were dispersed intermittantly about the graft area (no elinical photograph avaliable).

Histologically, the epithellum appears to have almost completely degenerated $(\mathrm{Plg} .10)$. Only a few cells in the deeper layers of epithelium can be distinguished as structurally Intact (flg. 11). The overall appearance of the epithellum, except for the basal layer, glves a "Swiss cheese" efrect, with nucle 1 ither faded, shrunken, or absent. 40

There is a soblance of basement membrane in only a few areas. Acute and subchronic Inflammatory cells are present in the conneotive tissue. Collagen tlasue at this stage appears to be regenerating and some healthy appearing fibroblastg can be identified. There is some endo- 
thelial proliferation, but few red blood cells present inside the vessels. 40

\section{Seyen day eost-frozen exaft}

A blopsy was not scheduled to be taken at seven days, however, since the acrylic splint was removed at this time, a clinical photograph taken to show the first full view of the entire graft after placement of the splint at surgery (fIg. 12). The graft still appeared whitish in color and well adherent to the reciplent site. It was surrounded by numerous areas of granulation tissue which covered the exposed periosteal tissue provided by the surgery. The white area seen overlying the genial tubercles was probably due to the irritation produced by the acrylic splint. Histologically, Korman ${ }^{40}$ describes evidence of regeneration in the eplthelfum. This is seen primarlly in the basal layer where individual cells are discernible with some semblance of organization. Mitotic figures can also be seen in the basal layer (11E. 13). However, there is a disruption in maturation such that cell layers, other than the basal cell layer, are not clearly differentiated (fig. 14).

Cells in the superficlal layers have pale staining nuclel and foamy appearing cytoplasm. Capillary formation and chronic inflammatory colls are seen in the underlying 
connective tissue.

\section{Nine and ten dax post-frezen scrafts}

Clinically at nine days, the graft tissue appeared to be more blended into the surrounding tlasue, al though it was still white in appearance and rough in texture. The graft is seen at the depth of the vestibule in fig. 15. Superior and lateral to the graft, more reddened areas can be observed. These areas represent granulation tissue overlying exposed periosteum left at surgery. HIstologically, at ten days, the post-frozen graft In Korman's ${ }^{40}$ study shows lacking of maturation in all sections of epithelium. The cell layers are indistinct. Cells in the upper epithelial layers are pale staining and some cells have intracellular globules of eosinophille material. Other cells in the upper layers have shrunken or missing nuclei and foamy, pale cytoplasm. No keratohyline granules can be observed, The basal layer, however, shows mitotic activity (1ig. 16). The basal lamina is well defined in certain areas and appears to be lifting away from the lamina propria. The connective tissue appears young and proliferative. Capillarles can be seen in some sections and few inflammatory cella are present in the connective tissue. 


\section{Twelve day post-frezen graft}

At twelve days, clinfical inspection of the graft shows good incorporation into the surrounding tissues with some diffioulty in determining the graft margins. The color of the graft has turned from white, as previously described. to coral pink and more closely simulates the color of surrounding tissues. The graft surface still remains rough in texture. Some areas of granulation tissue are still noticeable (fig. 17 ).

A tangential cut of eplthelium and connective tissue at twelve days is seen in Iig. 18. Intraceliular edema persists to a mild degree throughout the eplthelial layers with interspersed pyknotic nuclei. Widening of intercellular apaces is evident. empeclally above the basal layer. Some mitotle figures are seen in the basal cells. The connective tissue exhibits increased vascularlty with areas of amorphous appearing collagen. Chronic inflammatory cells are prevalent throughout the connectlve tissue. The epithellum is mildiy acanthotic.

\section{Eourteen and fifteen day post-frozen arafts}

At fourteen days, Korman ${ }^{40}$ describes the upper layers of epithellum as showing large globules of eosinophilic material (fig. 19), which probably stem from a coalescence of the eosinophillc material described at day ten. The 
stratum spinosum and basal layer are well defined. Mitotic activity is seen in the basal layer (1ig, 20). The connective tissue continues to be young and proliferative, with many capillaries and sub-acute inflammatory cells present.

clinically, at fifteen days, the graft site is partially covered with areas of granulation tissue. More granulation tissue than seen at twelve days is present, and represent the only areas left of inflammation, for the remalnder of the graft is healthy in appearance with graft margins difficult to distinguish (fig. 21 ).

\section{Nineteen day post-frozen graft}

clinically, the graft is well attached to the underlying and surrounding tissues. Some blebs of granulation tissue still prevail. The graft is now smooth in texture and healthy in color. Palatal rugae formation can bo observed in the midiline (fig. 22),

Histologically at nineteen days, the epithelium shows signs of mild dyskeratosis (fig..23). Pyknotic nuclel and signs of Intracellular edema are still prevalent. Parakeratosis in the stratum corneum is abserved. Mitotic flgures are till numerous in the basal cell layer (fig.24). In several areas, the basal lamina appears to "dip" between basal cells and continue into the intercellular spaces (fig. 24, arrow). The connective tissue shows less 
inflammatory cells than seen at fourteen days. However, amorphous appearing collagen is still present.

\section{Suenty three day noat-froren draft}

clinically, the graft appoars weil healed and blended into the surrounding tissue (f1g. 25). Good differentiation of cell layers throughout the eplthellum is present histologloally, but sone ayskeratosis still prevalls. Basal cells till show numerous mitotlc figures. The connective tissue shows ome signs of chronic inflamation (11g. 26).

\section{Thinty day nost-frozen scaft}

At thirty days, healthy palatal tissue lies in the mandibular vestibule surrounded by healthy appearine oval mucosa and distinot rugae formation can be detected (fig. 27).

Histologically at thirty days, the epithelium appears normal with all coll layers intact in the absence of pathologic changes (fig. 28). Parakeratosis of the stratum corneum, keratohyaline granules in the stratum granulosum, and 11 developed spinous and basal cell layera are all evident. The basement membrane is well derined. The connective tissue is till young though less cellular and vascular than the fourteen day specimen. Few inflammatory cells are present. 


\section{B.. Sequentlal Ul trastructural Healins Study}

\section{Zere day fresh uraft}

An electron micrograph of fresh palatal tissue shows epitheliur at the level of stratum spinosum (1ig. 29). This polyhedral shaped cell presents a normal architecture. The nuclous is surrounded by an intact double membrane (NM). The ehromatin (cr) pattern is well organized. The cytoplasm (C) is rich in ribosomes $(x)$ and tonofilaments ( $t)$, which coalesce into tonofibrils ( $T$ ). Numerous round mitochondria (m) with well defined cristae (ci) seem to be more concentrated in the perinuclear regions. Only a few profiles of granular endoplasmic reticulum (er) can also be observed in the cytoplasm. The plasma membrane $(P)$ is well preservad, showing numerous interdigitations between adjacent spinous cells, and abundant attachnents including desmosomes (d) and tight junctions $(t j)$, all morphologically intact.

Fig. 30 shows a higher magnification of a spinous epithelial cell from the fresh graft. Tonofibrils (T). ribosomes $(r)$, and mitochondria are unremarkable. The latter are surrounded by intact membranes and contain well preserved cristae (ai). Desmosomes (d) showing the typical lamellar structure are seen paralleling adjacent cell membranes. Tonoflaments $(t)$ converge upon the attachment 
plaques of the desmosomes in perpendicular direction. Several tight junctions ( $t j)$ also serve as attachments in the intercellular space.

The eplthello-connective tissue junction with a portion of one basal cell is observed in fiz. 31. The basal cell is clearly separated from the underlying connective tissue by the undulating, somewhat homogeneous, basal. lanina (b1). Numerous hemidesmosones (hd) project into the basal lamina on the epithelial side. The basal cell show a normal cytoplasmic array of free ribosomes $(x)$ and tonofibrila ( $T$ ). Several round mitochondria (m) are present adjacent to a proflle of dilated endoplasmic reticulum (er), On the connective tissue slde, numerous transversally cut collagen bundles (CO) are evldent, as well as ragments of a few flbroblasts $(F)$. Plg. 32 shows a low power magnification of freah palatal connectlve tissue. Depieted in the center of the electron mlerograph is a flbroblast (F) cut in cross section. It shows a normal nuclous $(N)$ and chromatin pattern (cr) wh th intact double nuclear membrane. Numerous mitochondria (m) are present in the cytoplasm (c) with well preserved exlstae (ci) formations, Ribosones and fibrillar elements are dispersed throughout the cytoplasm. The plasma membrane $(P)$ is intact. Adjacent to the 
fibroblast are collagen bundles (00) cut in tangentially and in cross section.

\section{Zere day post-frozen araft}

Fic. 33 is a low power electron micrograph of epithellal cells at the level of stratum spinosum. The nuclel (N) of these colls appear shrunken and pyknotic, with a low nuelear-cytoplasmic ratio. They are in different states of preservation. The nucleus of cell tit has a double nuclear membrane which appears to have undergone cytolysis. The chromatin (or) is abnormally clumped and part of the nuclear contents appears to have extruded Into the cytoplasm. The nucleus of coll ta 2 ahows similar types of chromatin abnormalities, but with better preservation of the nuclear membrane (m).

The eytoplasm of thease epithelial cells show obvious changes in the organelles. All cells cloarly demonstrate disrupted profiles of endoplasmic reticulum (er). Some an tochondrial outlinea (m) are observed wh no evidence of organization or cristae. Areas of clumped ribosomes (r) and tonofibrils (s) are also ovident. There is a difference of staining quality between cells, with cell \#2 being obviously more osmiophille. The aytoplasm of cell \#2 is in general, more homogeneous in nature. The intercellular spaces between some cells are widened, and 
show a decreased number of desmosomes in areas (arrows). Fig. 34 shows a high magnification of an epithelial cell at the spinous level, with a fragment of an adjacent cell. Abnormalities throughout the cytoplasm and nucleus are similar to those described for $f i g .33$. with more asily discernible clumping of their contents. A distinction between chromatin clumps and nucleoll cannot be made within the nucleus. Outlines of mitochondria (m) lack any cristae structure. Clumplng of ribosomes ( $r$ ) and tonofibrils (T) is more pronounced in the more osmiophllic cell (H), Some desmosomes (d) seem to have a well preserved lamellar structure with convergence of tonofilaments $(t)$ onto their respective attachment plaques, Other desmosomes, however, have undergone degeneration (arrow).

Fig. 35 is a high power electron micrograph of the intercellular space between spinous epithelial cells. Most obvious are the quite distinct desmosomes (d) with well preserved architecture. A lamellar type structure with seven distinct zones is clearly desmonstrated. A well preserved tight junction ( $t j$ ) may also be observed. The intercellular spaces (ics) are markedly widened. Fig. 36 is a low power view of connective tissue. Several fragments of flbroblasts (F) are seen containing 
sharply defined nuclel $(N)$, but no clear evidence of intact plasma membranes. The nuclear morphology of these cells is quite disrupted with clumping of chromatin similar to that seen in the epithelial cells (arrow). One cell shows a distinguishable nucleolus $(n)$. Cytoplasmic organelles are scattered in a haphazard fashion among and between cells with disruption of their normal architecture and conthulty. There is evidence of inter- and intracellular edema. Collagen bundles (CO) cut both transversely and longitudinally, are interspersed throughout. They are falrly well preserved, but sparse. Fragments of a degenerated macrophage (M) are also observed.

\section{Two day post-frezen eraft}

An epithelial cell from the stratum spinosum is seen in 11g. 37. The nucleus $(N)$ is pyknotic but intact with a falrly well preserved double nuclear membrane. Perinuclear edema can be observed. Clumping of chromatin (or) is evident, especially adjacent to the nuclear membrane. Numerous mitochondrial shells (m), lacking cristae or internal structure, are observed, especially in the perinuclear regions. Some disrupted profiles of endoplasmic reticulum (er) are also seen. Tonofibrils $(T)$ are distributed throughout the cytoplasm and reaain in a fairly good state of preservation. The ribosomes $(r)$ are extremely 
sparse. The intercellular spaces (ics) are widened with some well preserved attachment devices. A difference in staining quality is noted between cells 1 and 2 .

Fig. 38 is a low power electron micrograph of connective tissue at day two. Collagen fibers (Co) cut transversely and longitudinally are sparsely interspersed throughout. Most notable is a clearly distinguighable capillary (Ca) with a well preserved endothelial cell (E). The nucleus $(N)$ of this cell is normal in appearance, wth double membrane and well preserved chrometin pattern. In the lumen of the capillary, there are remnants of degenerated blood cells. Extravasated into the connective tisaue space are two poorly preserved neutrophils (Ne). Two fibroblasts $(F)$, with abnormal nuclear and cytoplasmic architecture, can be seen lining the capillary.

Fragments of two flbroblasts (F) can be seen in fig. 39. Clumping of chromatin in both nuclei (N) as well as honogeneous cytoplasmlc contents can be observed. Both colls show a clear zone partly surrounding the nucleus representing perinuclear edema. No mitochondria or proflles of endoplasmic reticulum are observed. In cell \#2 there are two large vacuolos containing osmiophille material. These structures are consistent with "Ilpid bodies (LB)." 


\section{Eive dav post-frezer raft}

TiE. 40 is a low power view of epithelial. cells at the spinous level. Signs of intercellular and perinuclear edema are still evident at this stage. The nuclel (N) exhibit a partly well preserved double nuclear membrane (Ni), but still show clumping of chromatin, especially adjacent to the nuclear menbrane (arrow 11 ). The cytoplasmic contents are still poorly preserved. Empty vesicles which are compatiole with mitochondrial remnants (m), and scattered profiles of swollen endoplasmic reticulum (er) can be seen. Only a few, short tonofibrils (T) can be distinguished. Clumps of a granular material (arrow 2) can be seen throughout the cytoplasm. At this magnification, the structure of these clumps is not clear, but we might suspect a ribosomal origin. The intercellular spaces are only allghtly widened and fairly good preservation of desmosomes is detected.

FIg. 41 is a medium power view of the epithlio-connective tissue junction at day five. The basal lamina (bI) is well delined with poorly preserved hemidesmosomes (hd) spaced irregularly alone its ept thellal border. Collagen bundles $(\mathrm{CO})$ in oross-cut and loneltudinal sections are seen in the connective tissue and are in a poor state of preservation. On the epithelial alde, the incer- 
cellular spaces (lcs) are still widened, but desmosomes, although few in number, appear intact. The nuclef and cytoplasmic contents show clumping and degeneration.

Pig. 42 is an electron micrograph of a fibroblast (F) seen at medium power. The nucleus $(N)$ is woll defined and intact with some perinuclear edema evident. It is difficult to distinguish nucleoll from clumped chromatin material (arrow) within the nucleus. Cellular organelles as granular endoplasmic retloulum (or) and mitochondria (m) are disrupted, showing slgns of degeneration. Clumping of cytoplasmic ribosomes is quite evident. The cell is well outlined by an intact plasma membrane (P). CollaEen fibers $(\mathrm{CO})$ and dispersed elements of degenerated cells surround the fibroblast.

\section{Nine day post-frozen sraft}

A low power magnification of transversely out basal epithelial cells (epithelial ridges) is shown in fig. 43. These cells are surrounded by a distinct basal lamina (bI). Well defined plasma and nuclear membranes are evident. Clumping of chromatin (cr) with in the nucleus is less pronounced than that seen in the flve day specimen. Mitochondria $(\mathrm{m})$, which are few in number, still show signs of disruption. A section of one neutrophil (Ne) In a fairly good state of preservation is seen. 
collagen bundles (Co), cut in various sections, are evident in the connective tissue in between the epithelial rldges. Myelin bodles $(\mathrm{mb})$, representine whorls of disrupted membranes, are present within the cytoplasm.

Fig. 44 ahows transwersely cut epithelial cells from rete ridges and a fibroblast (F). Within the fibroblast the cytoplasm appears to be rich in propiles of dilated endoplasmic reticulum (er), and a few mitochondria (m) in various degrees of preservation are present. Transversely cut collagen $\left(\mathrm{CO}_{0}\right)$ bundles are interspersed between all cells. The epithelial cells are surrounded by a distinct basal Lamina (b1), however, no hemidesmosomes can be distinguished. Only one eplthelial cell (ta) showed a section of 1 ts nucleus, which contained clumped chromatin. The plane of section of this particular cell must have included part of the nucleus and the underlying cytoplasm as well, since degenerated membranes and a "lipid body (LB)," which are normally seen in the cytoplasm, are seen in the center of the nucleus. The cytoplasm of this cell demonstrates a few profiles of dilated granular endoplasmic reticulum (er) and cross sections of what appear to be smooth endoplasmic reticulum (ser). The latter structures are distrlbuted throughout the cytoplasm. The cytoplasm of the other epithelial cells show lipid bodies (LB), myelin bodies (mb), numerous ribosomes, tonofila- 
ments $(t)$, and granular ondoplasmic reticulum (er).

\section{Twelve day post-frozen araft}

Fig. 45 is a low power magnification of basal epithelial cells and their junction wi th connective tissues at twelve days. The nuclei are of normal size and contour, showing double nuclear membrane and nucleoli $(n)$. The chromatin (cr) material is clumped only in a few areas and appears fairly well organized. The cytoplasm appears homogeneous at this magnification with evidence only a few organelles. Mitochondria with some apparent innerstructure can be seen. Interspersed throughout the cytoplasm are numerous dark staining areas appearing to be clumps of tonofibrils, which can often be seen in close association with what appears to be desmosomes. Areas of probable desmosome (d) formation are intermittently spaced alone the plasma membranes. There is very little interdigitation between cells. The intercellular spaces (ics) are filled with a homogeneous, osmiophilic substance. This substance appears similar in consistency to the basal lamina (b1), both the basal lamina and the intercellular substance appear to be continuous. The underlying connective tissue is barely distinguishable In this micrograph.

A high power lectron mlcrograph of basal eplthelial 
cells at the level of the intercellular space is represented in fig. 46. The cytoplasm (C) of the epithelial cells is relatively homogeneous, with an increased number of tonofilaments $(t)$, and fow rlbosomes $(r)$, A most interesting finding, and not previously reported in palatal tissue, is the formation of vesicles ( $v$ ) lining the plasma membrane. They measure approximately $600 \%$ in diameter. The vesicles are interrupted by areas of increased electron density, where the beginning of desmosome formation is suggested (arrow $1 / 1$ ). These vesicles could be related to those found in the nine day specimen, al though the latter were dispersed throughout the eytoplasm (11g. 44). In the otherwise homogeneous intercellular spaces (ics), increased areas of electron densIty are noted, corresponding to the electron dense areas in the cytoplasm of adjacent cells (arrow \#2). An electron dense line muning through the central portion of the intercellular pace can be distinguished in one inatance (arrow H). This line may correspond to the "intercellular contact layer" of the demosone, as described by Listgarten. 5

F1g. 42 is an electron micrograph of the epitheliom connective tissue junction at 12 days. The epithelial cell nucleus is similar to those described in fig. 45. 
In this electron miorograph, the above mentioned vesicular formations $(v)$ are seen linine the plasma membrane adjoining the basal lamina (ol). Similarly, vesicles cease to exist where electron dense areas in the cytoplasm abut the plasma membrane. This suggests the beginning formation of hemi-deamosomes. The basal lamina is quite distinct and homogeneous. On the connective tissue side, longitudinal sections of collagen bundles $\left(C_{0}\right)$ can be observed in a few areas displaying distinot periodicity. hore superficial layers of an amorphous and indistinct substance are noticeable.

Iig. 48 is a tangential section of a fibroblast within the connective tissue of the 12 day post-frozen graft. Most prominent are the two nucleoli ( $n$ ) within the nucleus. The chromatin materlal shows areas of condensation and clumping, primarily adjacent to the nuclear membrane. A double nuclear membrane is intact along wh thell-defined plasma mbrane $(P)$. The oytoplasm shows numerous profiles of dilated endoplasmic reticulum (er), and a few mitochondria in a poor state of preservation, Numerous ribosomes are also present throughout the cytoplasm.

\section{Elfteen day post-frozen maft}

Several cells at the level of the stratum spinosum 
are seen under low power in $f 1 g .49$. The nucleus (N) with double nuclear membrane and chromatin material are well preserved, Som areas just adjacent to the nuclear membrane show moderate increase in electron deneity of chromatin (arrows). Prominent nucleoll (n) are observed in one cell. The cytoplasm is rich in ribosomes and tonoflbrils whlch appear well organized. Numerous mitochondria (m) in aifferent atates of preservation (or regeneration) line the nuclear membrane. Some show evidence of eristae formation while most have a vacuolated appearance. No proflies of endoplasmic reticulum can be alstingulahed at this magnirication. The intercellular spaces (1ca) show marked widening with numerous well deflned desmosomes.

Fig. 50 repreants a transverse cut acrosg several basal cells apparently at the level of an eplthellal ridge. The nucleus of one cell is quite distinct $(N)$, showing an intact double nuclear membrane and clumping of chromatin material. especially notable along the nuclear membrane. The eytoplasm of these cells appears complex with numerous organelles. Small vesicles (approx. $600 \AA$ in diameter) are noted to be interspersed throughout the cytoplasm in all the cells (v). These vesicles appear simllar to proflles of smooth endoplasmic reticu- 
lum. Similar veslcles line up along the plasma membranes (P). As seen in the twelve day sections, when areas of electron density appear along the plasma membranes -representing possible desmosomal formation - the vesicles disappear (arrow 1 ). In many instances, the above described vesicles are intimately associated with the granular endoplasmic reticulum (arrow 2 ). The amount of endoplasmic reticulum is increased in these cello when compared to that seen in normal epithellal cells.

Poorly preserved mitochondrla (m) and several 11 pld bodies (LB) are also seen in alfferent areas of the cytoplasm. The intercellular spaces (1cs) are widened and fliled with a homogeneous material assumed to be the basal lamina (b1). Some ereas of hemidesmosomal fornation (ha) are noted.

The ept the 110-connective tissue junction 18 seen in fif. 51. The bagal cell: show Increased amounts of rough endoplasmic reticulum and vestcles as describod in flg. 50. However, more areas of condensation of fibrillar elements (presumably the beginning formation of attachment devices) are evident along the plasme membranes (P) and overlying the basal lamina (bI). Subjacent to the basal lamina is a fibrillar type material, possibly representing pre-collagen ( $\mathrm{pCo}$ ). 


\section{Nineteen dav post-frouen graft}

Fig. 52 shows a low power magnification of epitheIial cells at the spinous layer. The nucleus $(N)$ seen is well preserved with normal appearing nucleoli $(n)$ and double nuclear merabran (NM). The chromatin material shows normal distribution. Throughout the cytoplasm (C) there is an abundance of tonofibrils $(T)$ and ribosomes $(r)$. only a few mitochondria (m) can be observed at this power. There are numerous normal appearing and noderately widened intercellular spacos (10s).

Fig. 53 is high power electron miarograph of the intercellular space at the level of stratum granulosum. At this level, desmosomes (d) aro quite distinet with a clearly defined lamellar architecture. A thick condensation of tonofibrils abut the attachment plaques of the desmosomes. In several areas (arrows) the tonofilaments ( $t$ ) are gathered into dense fibrils, taking on somewhat of an organlzed structure, A keratohyaline granule (khg), typleal of this layer is also noted.

After numerous preparations of tissue form nineteen days, no sectlons of connective tissue lements or besal coll layer were obtained.

\section{Twenty-three day post-frozen graft}

Fig. 54 is an electron micrograph of a spinous 
epithelial cell. The nucleus (N), chromatin material (cr) and double nuclear membrane are intact, showing good organization. The ribosomes are plentiful and dispersed more uniformly than in the nineteen day specimen. initochondria (m) are numerous, showing good inner structure with cristae formation. Granular endoplasmic reticulum (er) is sparse and still lackine clarity. The intercellular spaces with numerous deamosomes (d) and some tight junctions ( $t j$ ) are normal in appearance. The eplthello-connective tissue junction is represented in fig. 55. The nucleus of cell ifl shows some signs of degeneration, noted by clumping of chromatin material (or). The nucleus of cell $\$ 2$ is more normal in appearance, Tonofibrils, ribosomes and mitochondria (m). in different states of preservation, fill the cytoplasm of these cells. Especially notable are numerous proflles of granular endoplasmic reticulum (er) seen in cell is. The plasma membranes are intact and well defined. Interposed botween these two epithelial cells and the basal lamina (b1) is another epithelial cell (f3). cut longitudinally. Vesicles $(v)$, similar to those seen at flfteen days are noted throughout the cytoplasm of these three cells. In some areas they Iine the plasma membranes. The basal lamina is homogeneous and is lined 
on the epithelial side by irregularly spaced hemidesmosomes (hd). On the connective tissue side there are cross-cut sections of collagen fibers (Co) which appear slightly degenerated.

\section{Thicty day nost-erogen exaft}

F1g. 56 is a low power lectron micrograph of spinous epithelial cells. Both cells show well defined nuclel with double nuclear membrane and well organled chromatin (cr). In one cell, a mell preserved nucleolus (n) is evident. The cytoplasm of each cell shows a normal pattern of ribosomes and tonofibrils. Mitochondria (m) are numerous, however, some lack crlstae formation. The intercellular spaces are within normal ilmits and show numerous interdigitations with adjacent cells. Degmosomes (d) are well preserved but fewer in number then those seen in previous biopsies.

F1g. 57 depicts a fibroblast within the connective tissue of a thirty day post-frozen graft. It is well preserved and shows an intact nuoleus $(n)$ and rell-defined nuclear membrane. Cytoplasmic organelles. Including mitochondria (m), and rough endoplasmic reticulum (er) are clearly discemible and in a good state of preservation. 


\section{CHAPTER V}

DISCUSSION

Glycerolization, freezine, thawing. deglycerollzation, and gubsequent autogenous transplant of palatal tissue is a successful procedure, as indicated in our studies by the maintenance of a viable donor graft in its recipient bed. This procedure, however, is not without damage to cells and interstitlal tissue. Ultrastructural studies of fresh glycerolized and deglycerollzed cells reveal disruption of most cellular membranes with extrusion of cellular contents, swelling, and disruption of cellular organelles, and homogenization or coarse clumping of chromatin material and other protein const1tuents. These alterations have been conflrmed by other Investigators. $40,59,62,64-67$

Preezing damage to both connective tissue and epithelial cells was quite evident in our zero day postfrozen grafts, although it appeared in varying degrees even among nelghboring cells. Disruption of the cell nuclear membranes in addition to homogenlzation and clumping of cell proteins (ribosomal and chromatin) as we have observed, has been explained by several theories. At slow cooling rates, as we utilized, lce crystal formation is restricted to extracellular spaces. 62,70 
Litvan 66 provides an explanation for the damage we have observed. He assumes that during the freezing process, intracellular ter remains liquid-like (supercooled) below $0^{\circ} \mathrm{C}$, and therefore its vapor pressure is greater than that of ice. Upon cooling, extracellular ice forms and a vapor pressure difference is created. This initiates extracellular water movement, thus creating a nonequilibrium state within the cell. Litvan ${ }^{66}$ suggests that equilibrium is restored by the gradual release of bound water (desorption) and subsequent excretion of the free water from the cell. The chief cause of cellular damage is probably due to dehydration and consequent denaturation. Glycerol, by increasing the viscosity of intra- and extracellular fluids, improves survival rate by diminishing the water migration rate and changes in partial pressures.

Mazur ${ }^{65}$ similarly theorizes that intracellular water remains undercooled as the temperature is lowered below $0^{\circ} \mathrm{C}$. and recognizes resulting changes in vapor pressure. He suggests that quilibrium is restored by water migration out of the cell leading to increased intracellular salt concentration that causes protein denaturation and cellular damage.

Considerable ultrastructural damage probably occurred 
during glycerolization of the tissue. ${ }^{71.72}$ since glycerol freely permeates the cell membrane, it changes the osmotic gradient and the lastic forces seeking to return cellular membranes to their original position. ${ }^{72}$ If the osmotic gradient is too great, rupture of membranes may occur. Certainly this can account for distention of mitochondria and other membrane bound organelles seen in our study (1ig. 37).

Sherman 67 , in his studies of eryoinjury to mitochondria of mouse renal cortex, found freezing damage in the form of mitochondrial swelling, change to globular shape, precipttation and loss of matrix, loss of dense granules, and Irregularity and $108 s$ of cristae. Simllar damage to all mftochondrla was not observed. He suggests, concurring with finding by other authors, ${ }^{60.73}$ that differential sensitivity to factors causing cryoinjury varies from animal to animal, organ to organ, tissue to tissue, cell to cell, and even between cells of the same type within the same animal. He also showed that pretreatment with cryoprotectives alone before freezing produced al terations, primarily in reduction of cristae.

Using osmotic shock, streptolysins, and cycles of freezing and thawing. Bendall and deDuve ${ }^{74}$ found lysosomal membranes more sitive to this type of insult than mito- 
chondrial membranes. Me1lors 75 and co-workers showed that when lysosomal membranes are injured, thelr hydrolytic enzymes are released with subsequent damage to mitochondria in the form of awelling, uncoupling of oxidative phosphorylation, and colncident physical alterations in cristae and matrix. Furthermore, Allison and paton ${ }^{76}$ have shown that activated lysosomal enzymes, released when lysosomes are injured within cells, are capable of damaging chromosomes as woll as mitochondria. Certainly, our post-frozen grafts showed ultrastruetural changes as described above.

Muclear damage with clumping of chromatin, in addition to cytoplasmic ribosomal damage, as we noted in all post-Prozen cella, can becounted for by denaturation of protein from increased salt concentrations, action of hydrolytic lysosomal enzymes or desorption of "bound" water -- all mentioned above. This damage, however, was apparently reversible, for at 9 days, nuclear chromatin clumpling appeared less severe. More granular endoplasmic reticulum was also evident at this time, although otill in a disrupted tate, ribosomel lining of these membranebound organelles was more distinct and organization more evident. Complete integrity with a normal appearance of these tructures varied in different tissue layers at different stages throughout the healing process. 
Sequential healing studies of frozen, thawed and grafted oral mucosa, performed by Korman ${ }^{40}$ at the light microscoplo level, showed signs of morphologle regeneration in seven days. This was observed at the level of the stratum basale, the cells of which showed architictural integrity and numerous mitotic flgures. The upper levels of eplthelium, however, presented slgns of degeneration through fourteen days. Our live day uItrastructural survey also showed signs of degeneration while our nine day specimens revealed the beginning of a regenerative process. We must then assume that the mucose begins its recovery phase from freezing damage lenst one week after the grafting procedure.

It must be emphasized that with an ultrastructural study as we have performed, a concomitant 1ight microscopic analysis must be carrled out. The ultra-high magnification provided to us by the electron microscope enables us to observe more intrlcate changes within each cell, e.F., membrane structures, Integrity and position of organelles, and minute alterations of nuclear and cytoplasmic contents. On the other hand, 11ght microscopy gives us a broader pleture of changes within groups of cells and nelghboring tissues. Speciflc degerierative processes, cellular damage and timing of repair may then 
differ by exoh method of analysis.

In our ultrastructural studies, the indtial signs of recovery were evidenced as early as nine days by a decrease in the clumped appearance of both ribosones and chromatin material. These signs became more pronounced by 15 days, at which time abnormally large amount of gran ular endoplasmic reticulum were observed in the basal epithelial sella. This is compatible with a recovered potential of protein synthosis.

The vesicular formations observed at 12,15 , and 23 days re only found in basal cells. Thehighest concentration of these vestcles was found in and about the increased profiles of granuler endoplasmic retleulum at 15 and 23 days, and along the plama membranes at days 12 and 15. The vesicles lining the plasma membranes may play a precursor role in intercollular adhesion. This is more likely when we realize the increased amount of plasma membrane surface area provided by the vesicles (fig. 46). Further substantiation of this phenomenon can be seen where these vesicles disappoar and a more sophisticated type of intercellular attachment - in the form of a desmosome - develops. It may also be postulated that these vesicles later develop into the numerous interdigitations observed between mature cells, creating 
additional bonding.

The vesicular atructures which appeared in the cytoplasm of the basal cells at days 12, 15, and 23 were interspersed, and without an organized distribution. At times they were observed in close association with small, longitudinaliy cut tubules. It is possible that these vesicles represent profiles of smooth endoplasmic reticuIum cut in cross section and consequently play role in some type of transport or storage mechanism of protein. Sandborn ot al 77. In their investigations upon numerous types of rat tissue, found cytoplasmic microtubules (cross-cut sections appearing as amall vesicles) in all tissues examined. The description of these tubules was simllar to those seen in our study. They were found throughout the cytoplasm, often in close asaciation with cytoplasmic organelles, and frequently in contact with the plasma membranes. They suggest several possible functions of these mlerotubules, 1) supportive, 2) contractile, and 3) serving to transport fluids and suspended solids. They conclude that these microtubules may serve as a connecting channel between oytoplasmic organelles and the plasma membrane, creating a continuous membrane system. This concept of a mlorocirculatory system, functioning a transport device between organelles and 
plasma membrane, seems applicable to the basal cells we observed in an active state of regeneration.

It may be suggested in several of our flfteen day specimens (figs. 50 and 51) that the cells we term basal cells are in fact clear cells within the basal layer. as described by Thilander.? What appear to be melanosomes and numerous vestcular structures are dispersed throughout the cytoplasm of these cells. However, clear cellg lack sophistlcated intercellular attachments as desmosomes, Comparing these cells with clearly defined basal cells in the twelve and twenty-three day specimens (rigs. 47 and 55), similar desmosomal formations are evident along the plasma membranes where electron dense structures appear when the vesicles linine the plasma membrane cease to exist. With apparent desmosomes evident along the plasma membranes we must then assume that these are in fact basal cella, possibly with melanin imparted to them from adjacent clear cells, as suggested by zellokson. 6

our basal cells from days nine to twenty three, showed few interdigitations between cells which were separated by wide apaces fllied with a homogeneous type of cementing substance. This intercellular substance was frequently continuous with the basel lamina. Increased demand for nutrient supply by actively regenerating 
basal cells may also account for the se findings. Wldenod intercellular spaces in direct continulty, via the basal lamina, with the underlying connective tissue and capillary endings would serve to facilltate transport of matabolites and Increased levels of oxygen to these cells.

The lack of interdigitations between cells and increased amounts of intercellular mucopolysaccharides could also serve to facilitate the sliding of cells past one another. Irreversibly damaged cells at higher levels requiring replacement would possibly alctate a more rapid misration of cells from lower levels.

At 23 days, ultrastructural regeneration was still ovident in the besal cells. spinous cells at this time appeared nomal with only a mild degree of clumped chromatin material and abnormal concentrations of ribosomes in the cytoplasm. The intercellular spacen still appeared widened to a moderate degree. Iight nicroscopic sections from this stace of the healling process appear almost normal with widened intercellular spaces the only evidence of abnormality. Both ultrastructural and light mieroscoplc findines at 30 days were indigtingulshable from nornal keratinized oral mucosa.

In our clinical studles, graft adaptation and take was clearly evident seven days post-operatively (fig. 12). 
This concurs with findings by other authors. 39.40 At 19 days, complete clinical healine wes not evidenced in our study while other authors, ${ }^{39}$ utilizing similar gxafts, report complete clinical healine at 14 days. We must attribute the delayed healing response of our grafts to tissue injury from the glycerolization, froezing and thawing processes. 


\section{CHAPTER VI}

\section{SUMAnX}

The aim of this project was to study, on an uItrastructural leve1, the sequential healing phenonena whlch take place after froezing and thawn human pelatal autografts. Palatal tree prafts wore obtalned from four human subjects for use in mandibular rostibuloplasty. Two sme11 blopales of ach praft wero taken immediataly after procurement and wore labelled frosh tisme cantrols. All blopsfes were prepared for both 11 int and electron microscopy. The remaining tissues vere then glycerollzed, frozen in 11quid nitrogen at controlied rates, and stored for approximately one month. The tiseues vere then thawd, deglycerolized and transplanted autozenously to the anterior mandibular resion for the purpose of vestibular extension. Immediately prior to transplantation, amall biopsies wero again taken from each segment of tissue. These were dealsnated zero day poat-rozen srafts. Two blopsles were taken altornatively from each patlent at $2,5,9,12,15,19,23$ and 30 days.

All rrafta we success rul with complete clinical hea:Ing evident at 23 days. A sequentlal study by litht microscopy showed intial tissue damaze from freosing with comple te repelr by 23 days. The sequentid untrastructural 
study also revealed initial cryolnjury to cells, but on a nore intricate level involving speclelc cellular elements. complete regeneration was not evident by 23 days, however. at the ultrastructural level. Splnous cello at thirty days appeared normal. however basal cells from the thirty day specimen were not seen. There is indication for further investigation to determine completion of reseneration on the ultrastructural level. The electron microscople technique has served to more intricately elucldato regeneration of frozen and thawed tiseue at the cellular level. 


\section{ChAPren VII}

COROLIXIOH

Hutuan palatal wucos may be tycerollzed, rozen. stored. thawed and autogenously traneplanted with zuccess. Athough disruption and tiscue damage observed both on $21 \mathrm{ght}$ and electron moroseople level. thit was not

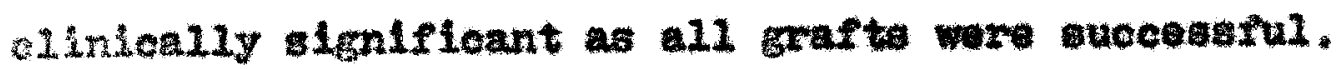

Ul tragtructural and 11 ht mlexoseople changes observed in our blopsy apecimene ware attributed to ${ }^{2} y^{\circ}$ cerolization, froezing and thatro processes, As ov1denced primarliy be our ul tratrue tural study, regenerathon of grafted ept thellun was efrected vin the basal cell layer. The formation of vesloular struetures and alteratons in both the basal lamina and Intaroellular subatances tay play a lenirlont role in this regonerative process. The electron mieroscope has served to alucldate chantses In regonorating cells not provlouely deseribed by 1 ght nicroscopy. 


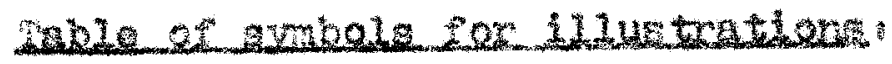

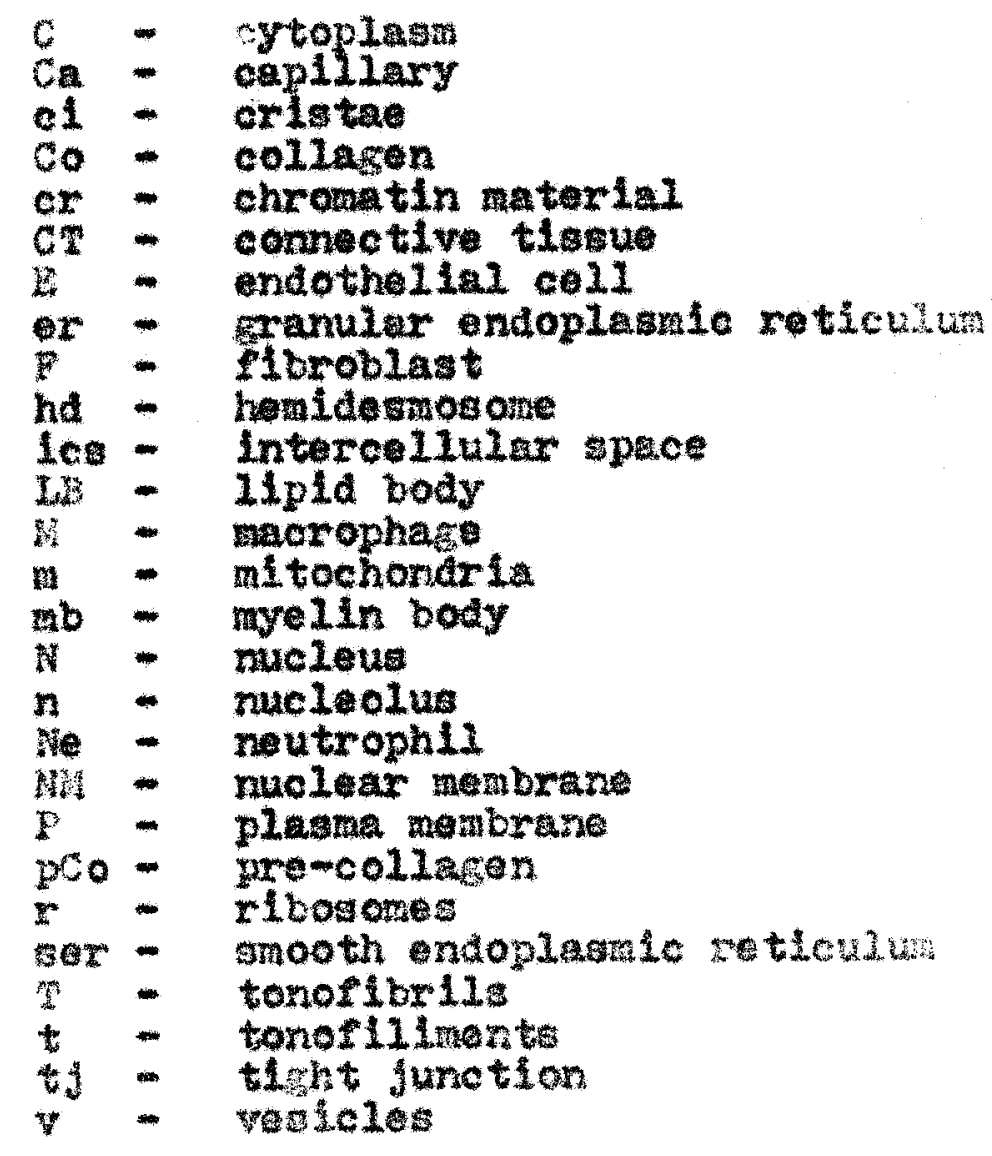




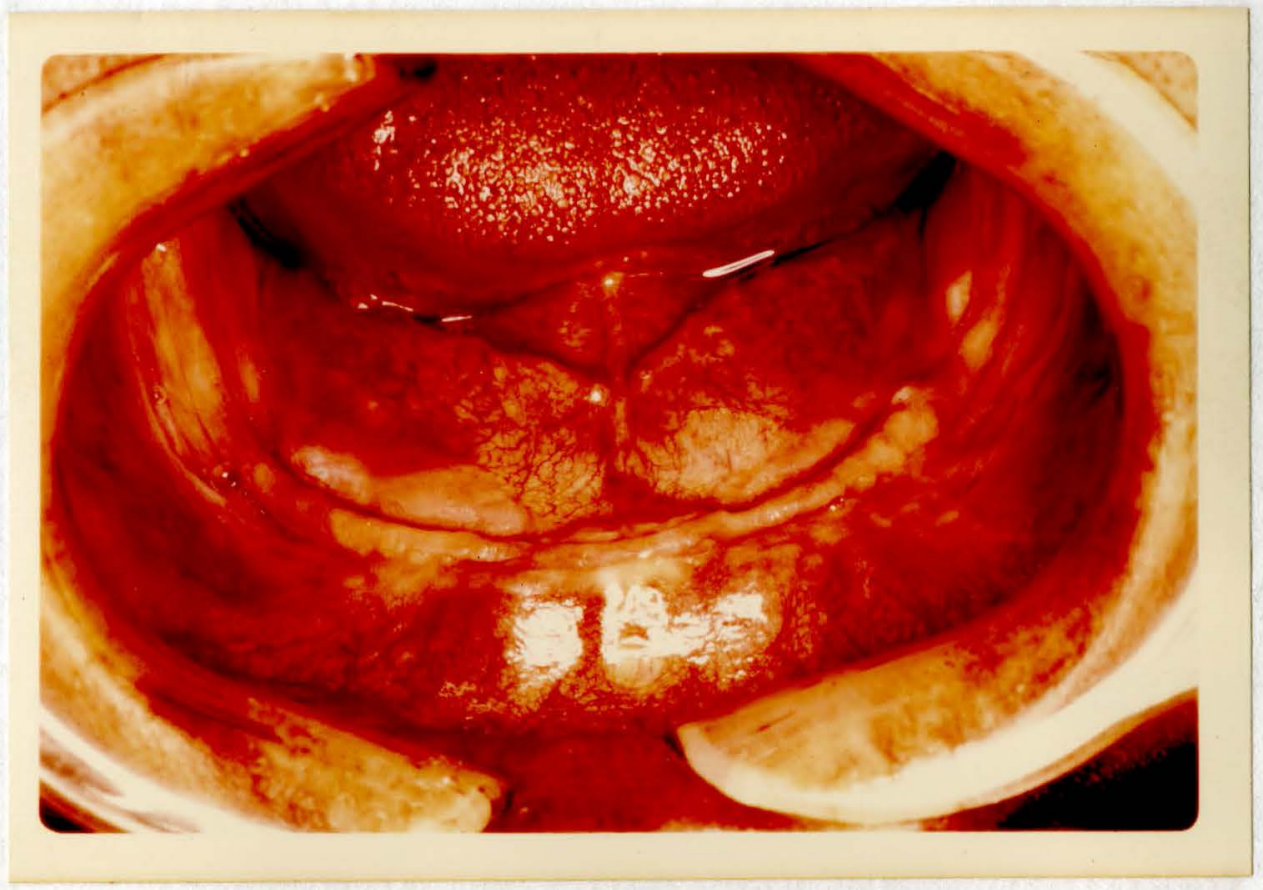

Fig. 1

Preoperative Surgical Site 


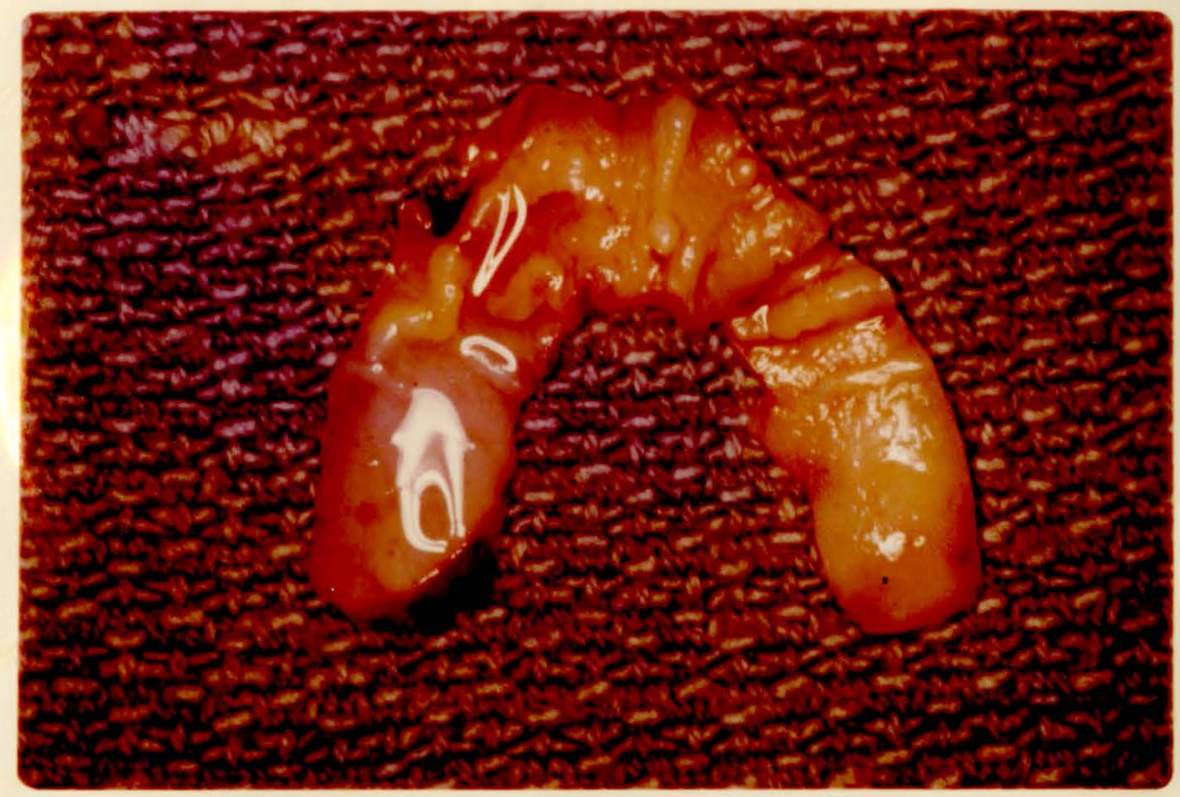

Fig. 2

Donor Tissue from Palate 


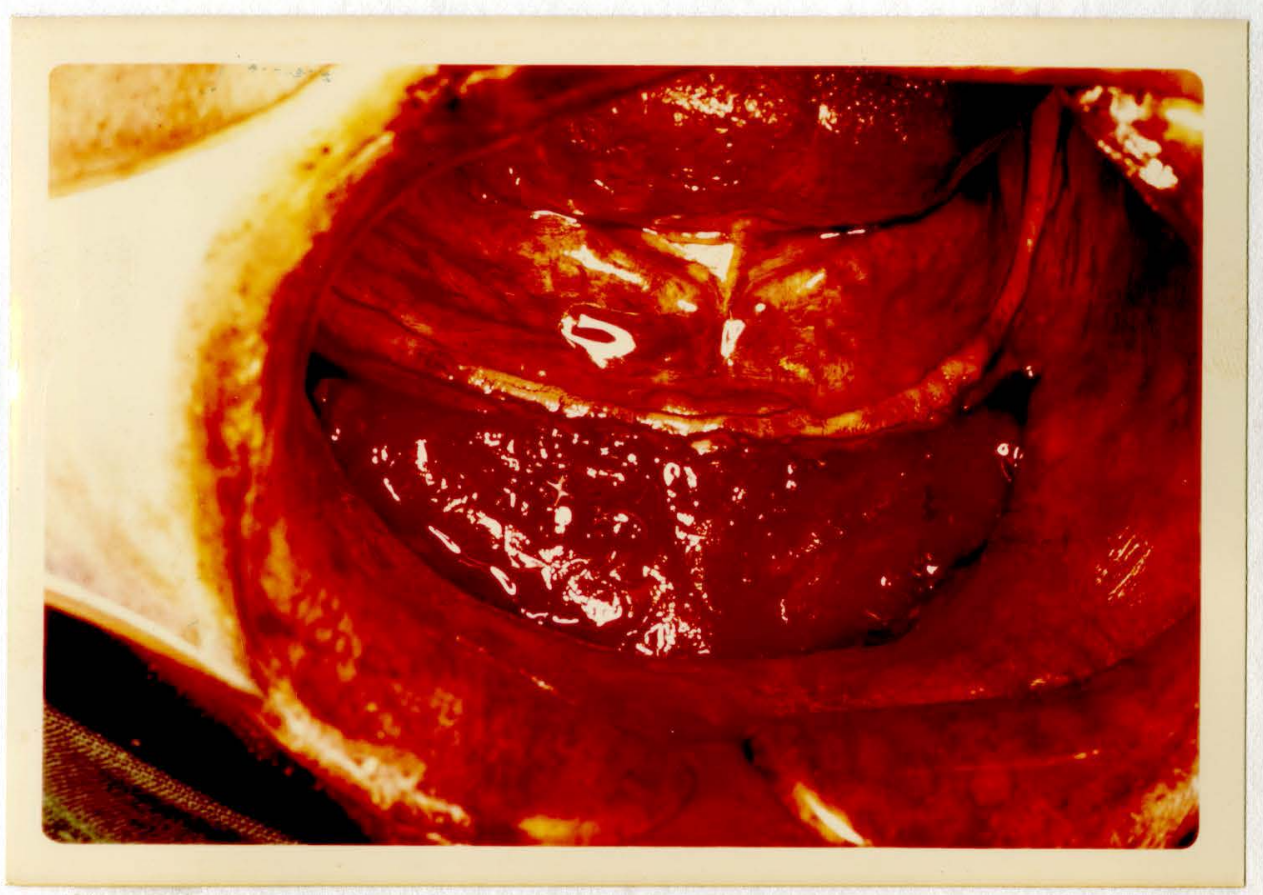

Fig. 3

Recipient bed before

placement of eraft 


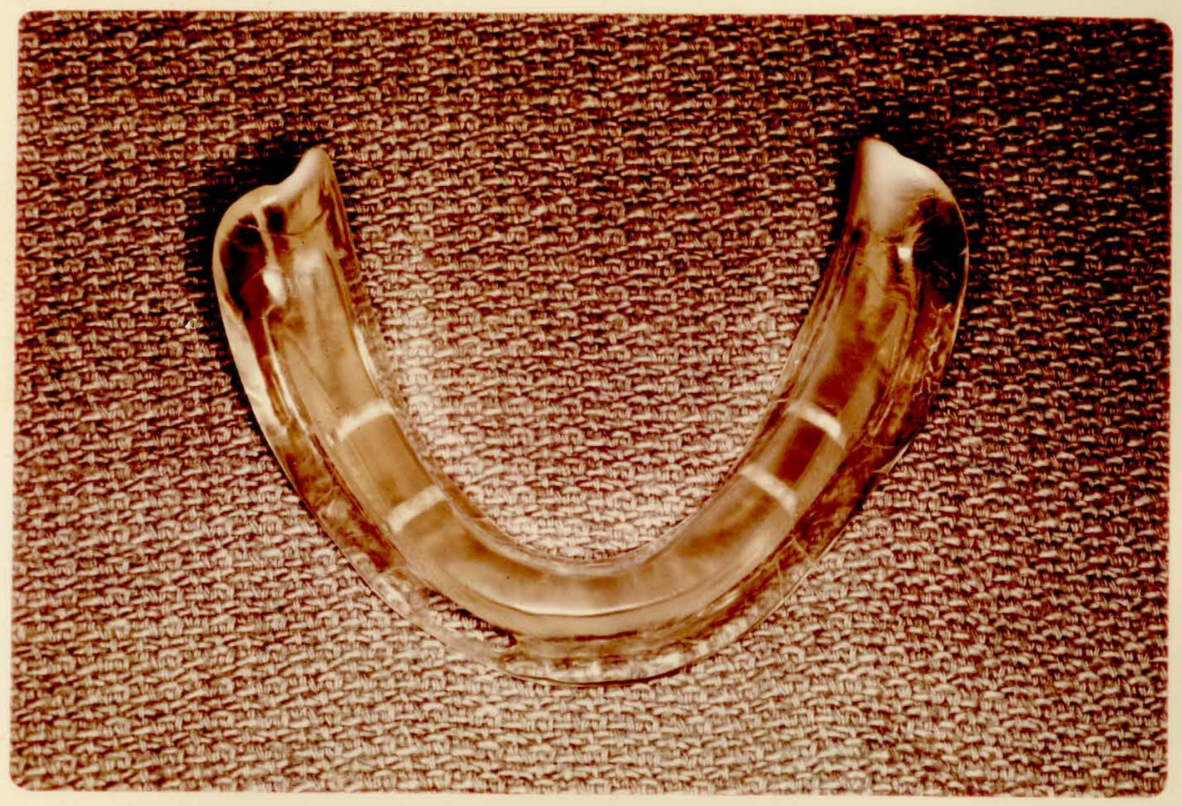

PIg. 4

Acrylle stablization splint 


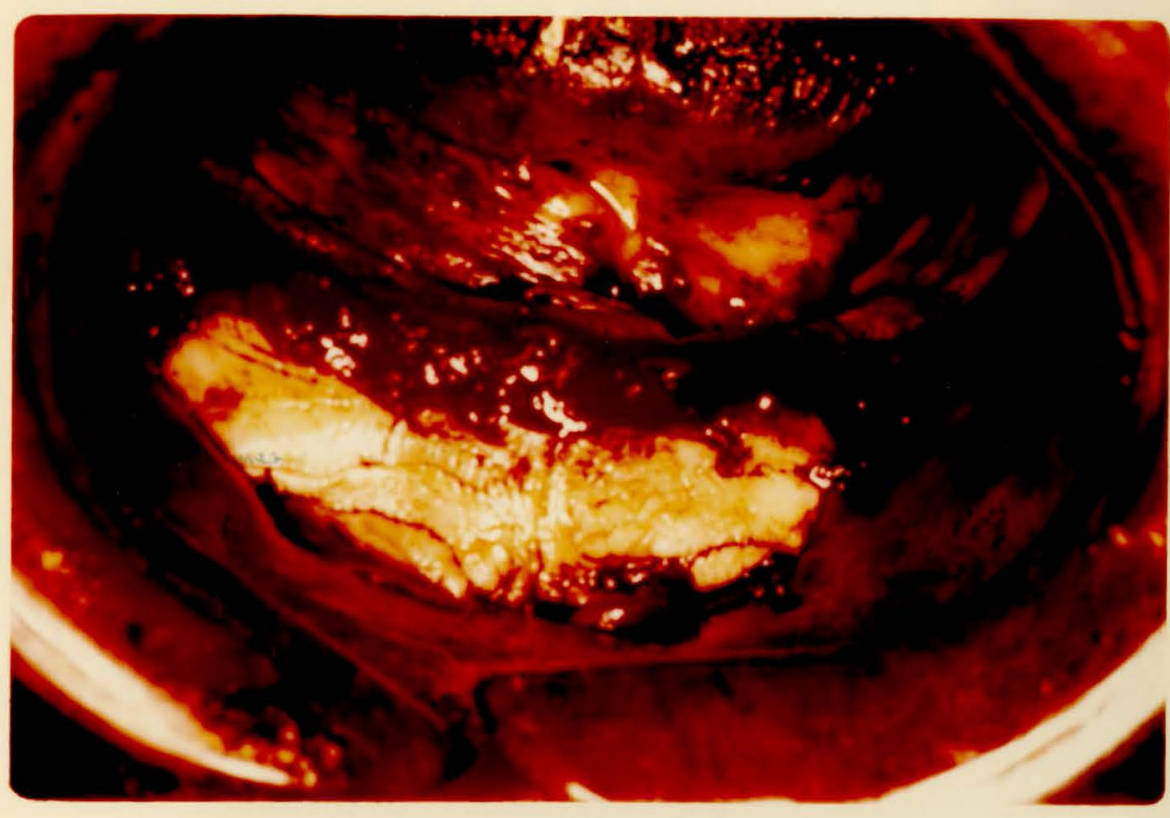

F18. 5

Graft sutured to place in recipient bed 


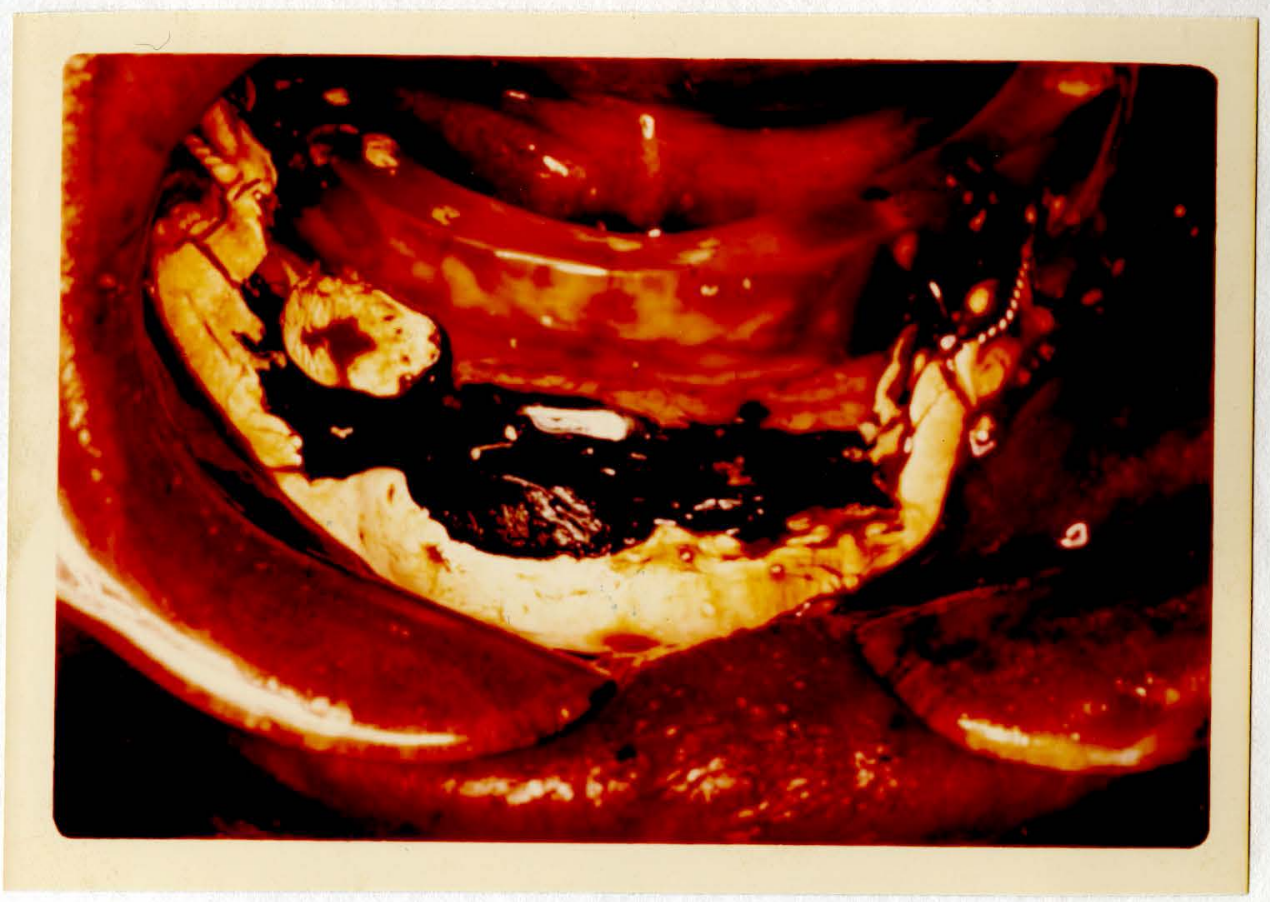

Fig. 6

Acrylic aplint in place

Note: hole provided in aplint for obtalnin early blopsy material. 


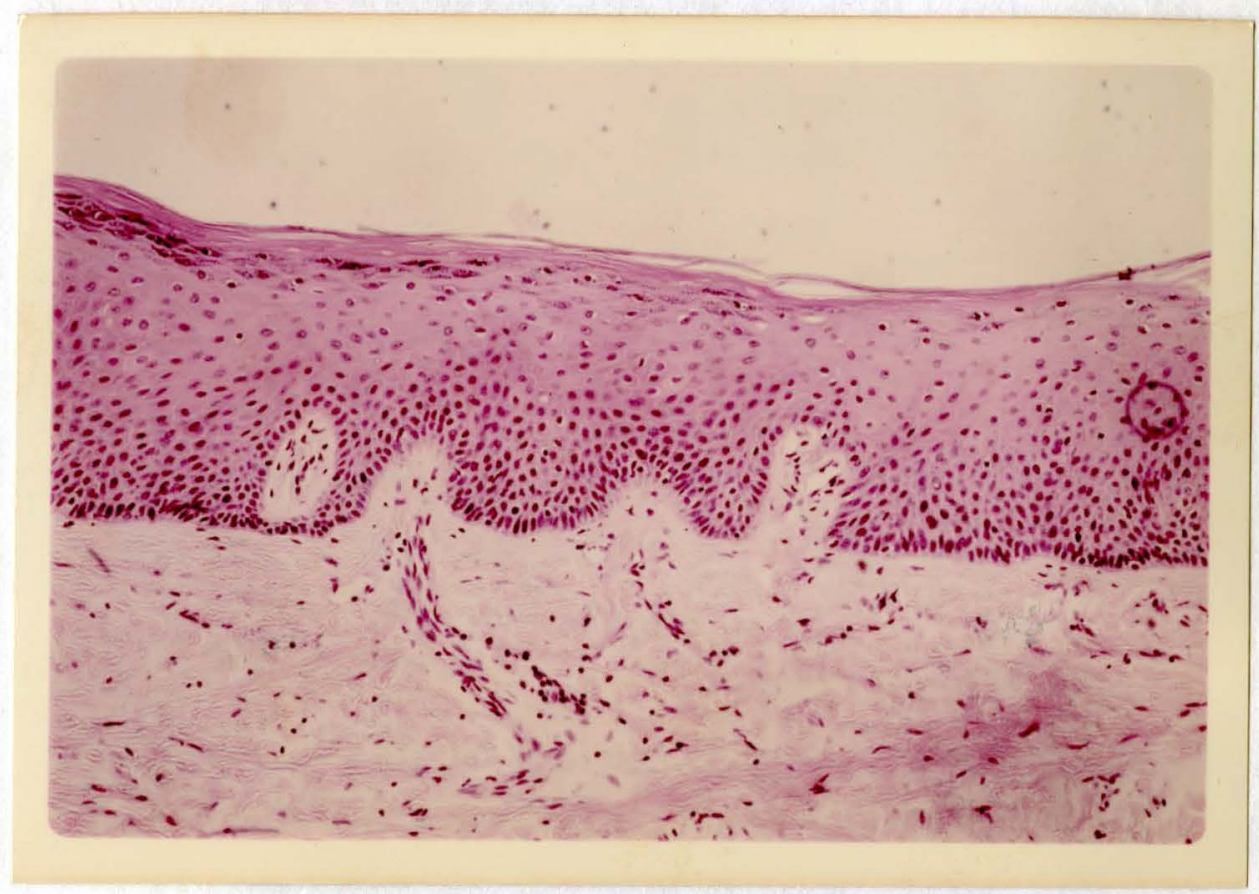

948. ?

o day biopsy (200x)

Note: ceneralized hydropic degeneration with perinuclear edoma 


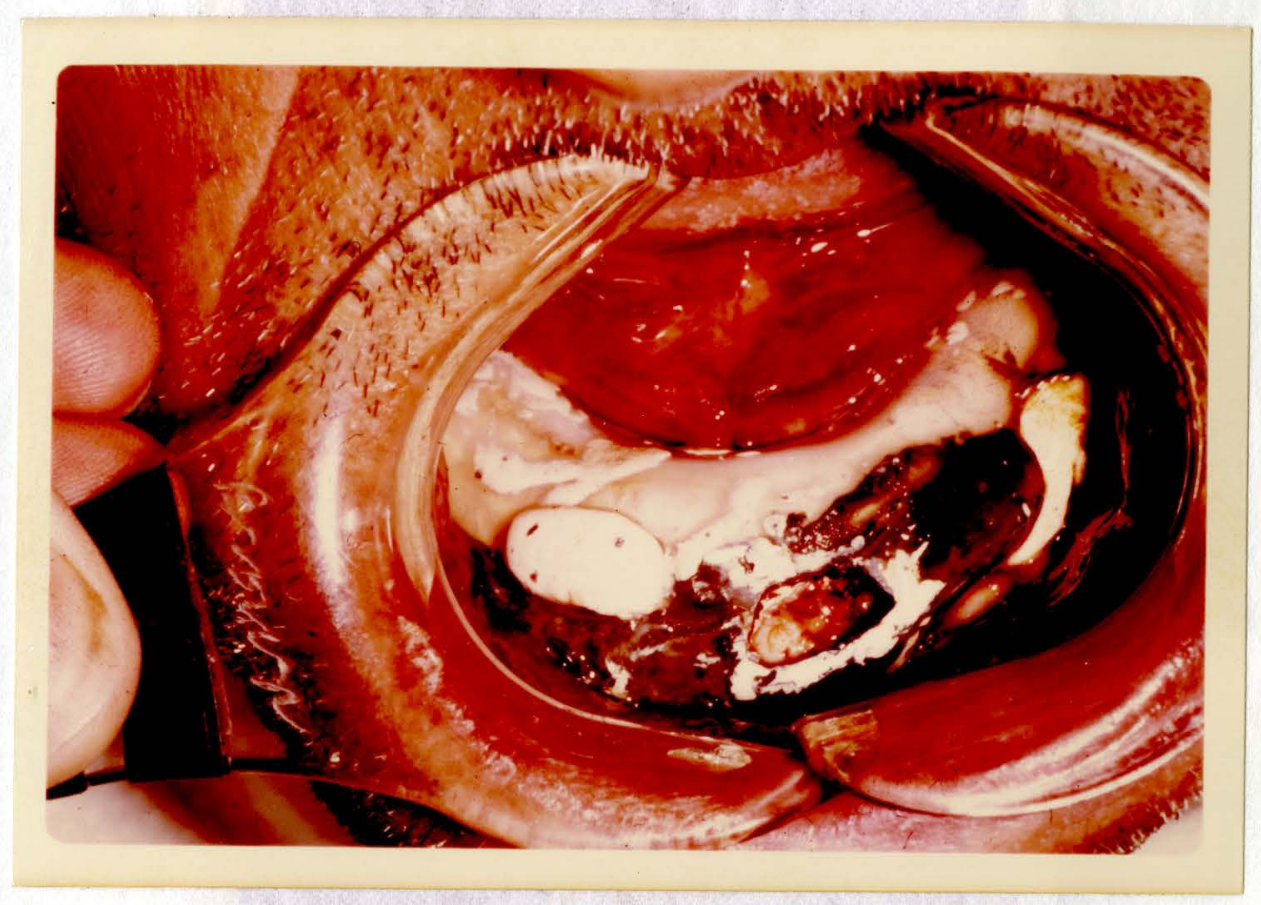

Fig. 8

2 day graft 


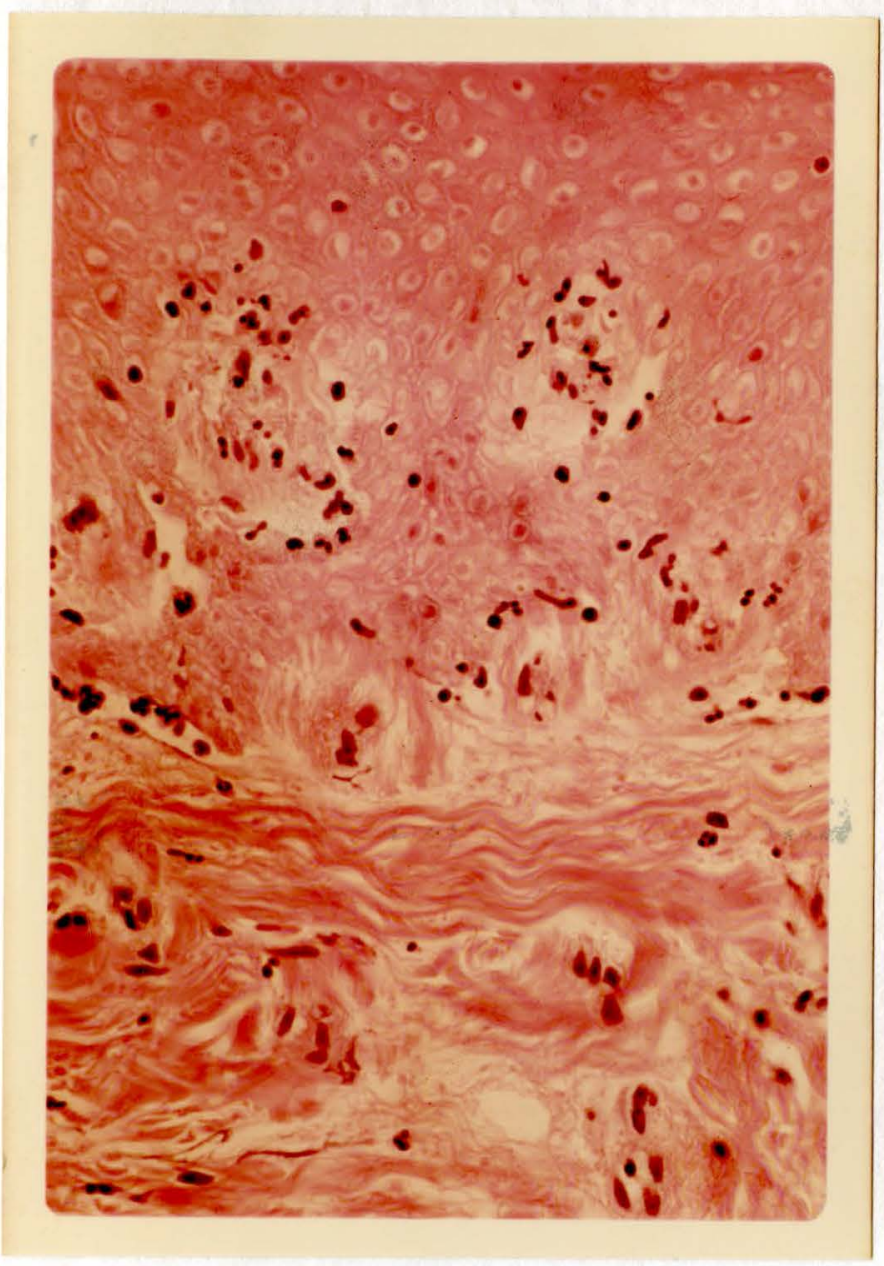

Fig. 9

2 day biopsy (250x)

Note: pale appearance of stretum basale and stratum spinosum and amorphous disrupted basal lamina 


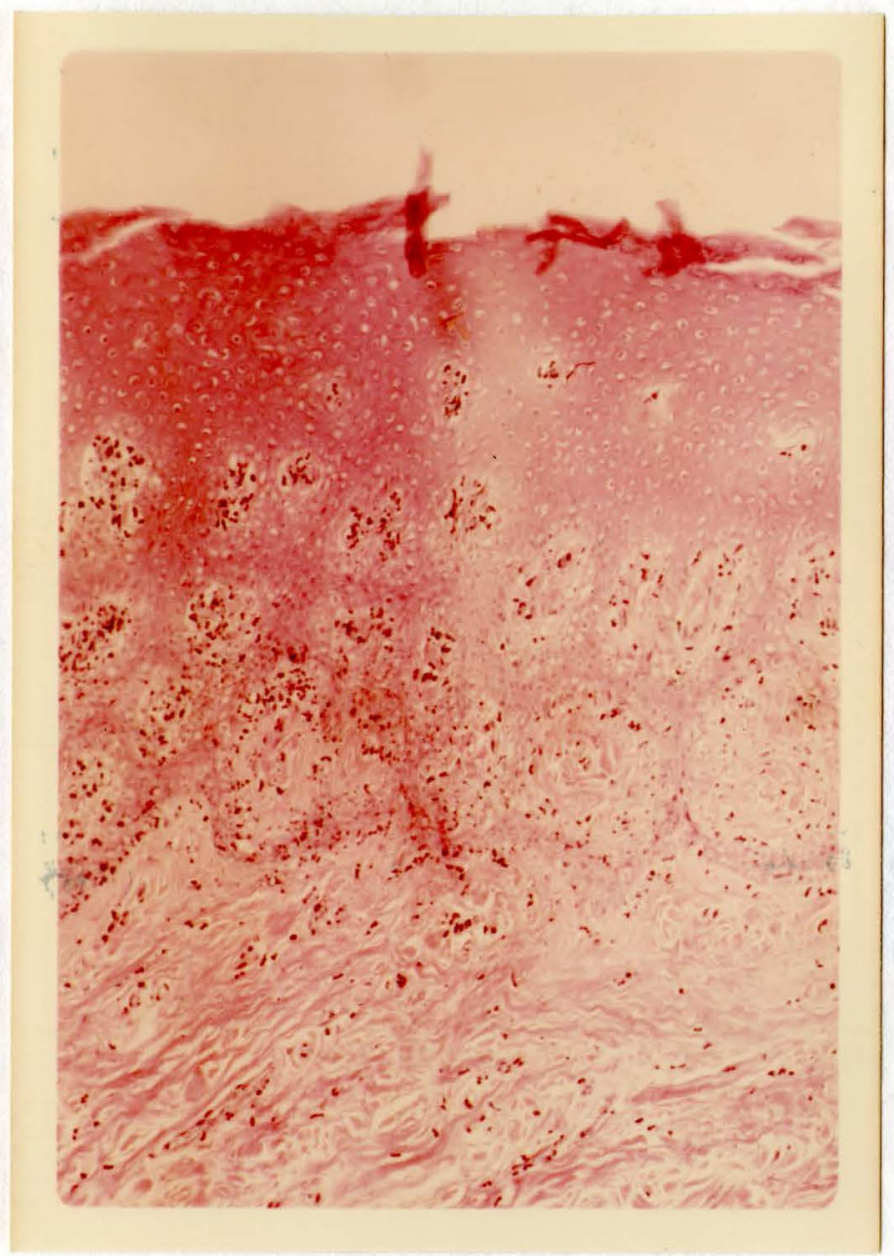

Fig. 10

5 day graft (100x)

Note: marked degeneration of epithellum with increased 11broblastic activity 


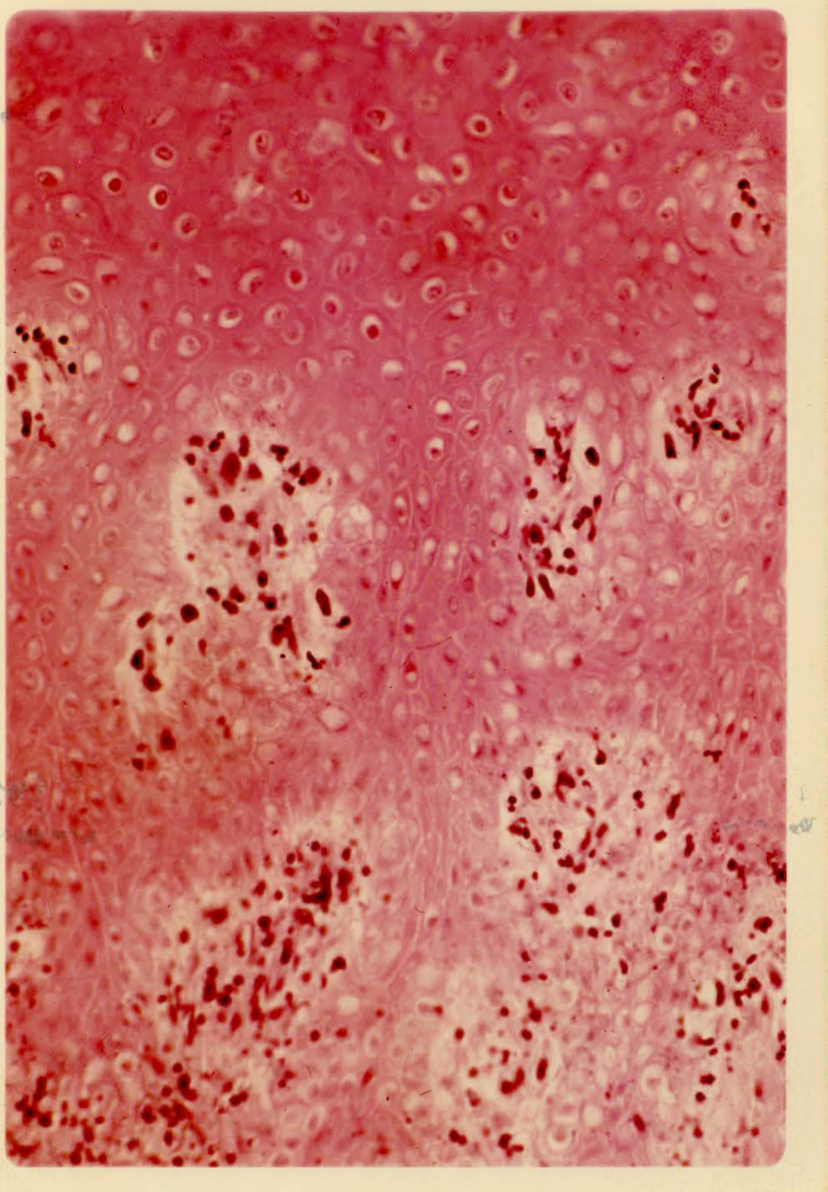

Fi.g. 11

5 day biopay (250x)

Note: extreme perinuclear edema with numerous light staining nuclei 


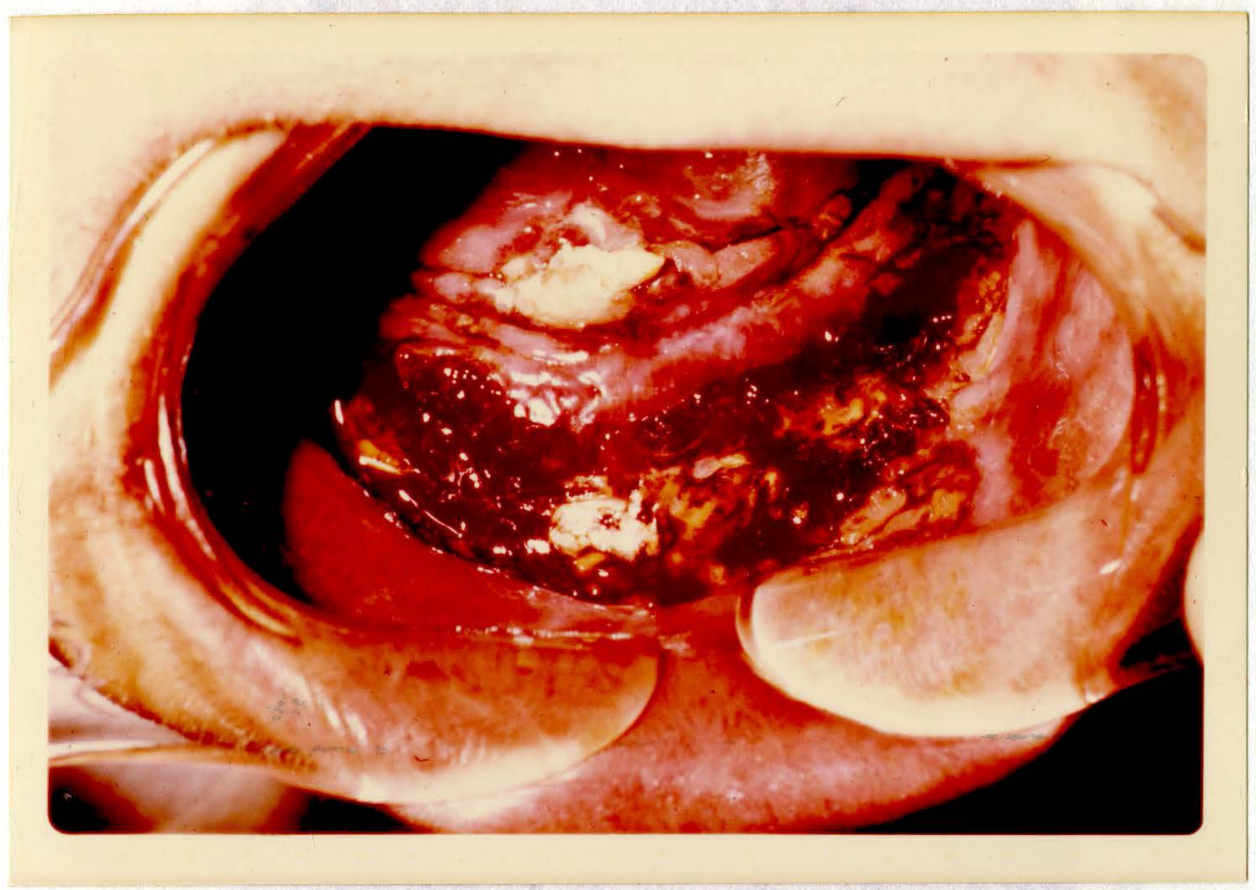

PS. 12

7 day grast

Notes arafe intact anidet an abunclence of eranulation tissue 


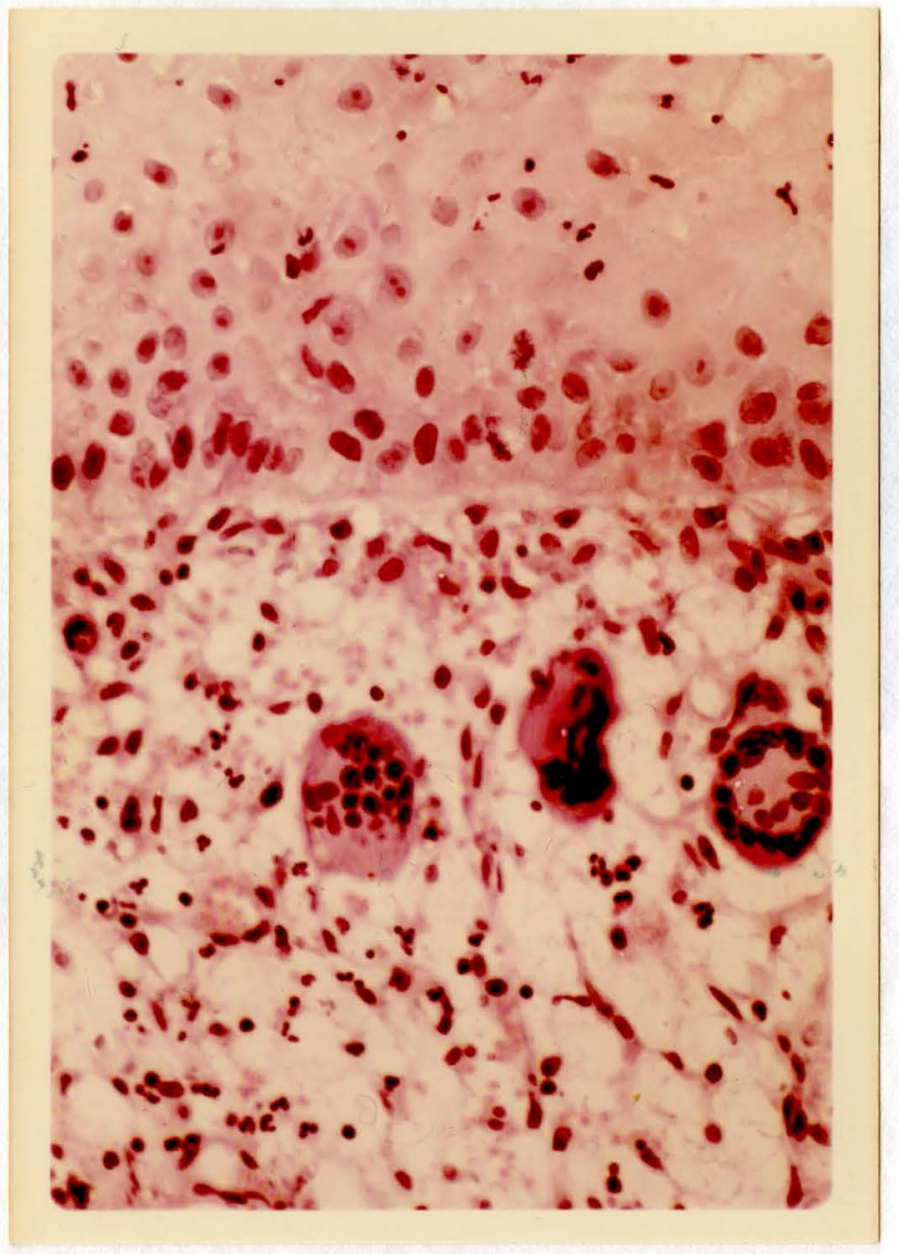

Fis. 13

7 day blopsy (250x)

Note: mitothe flgures in besel

layor and foreign body clant colls in connoctive tisguo 


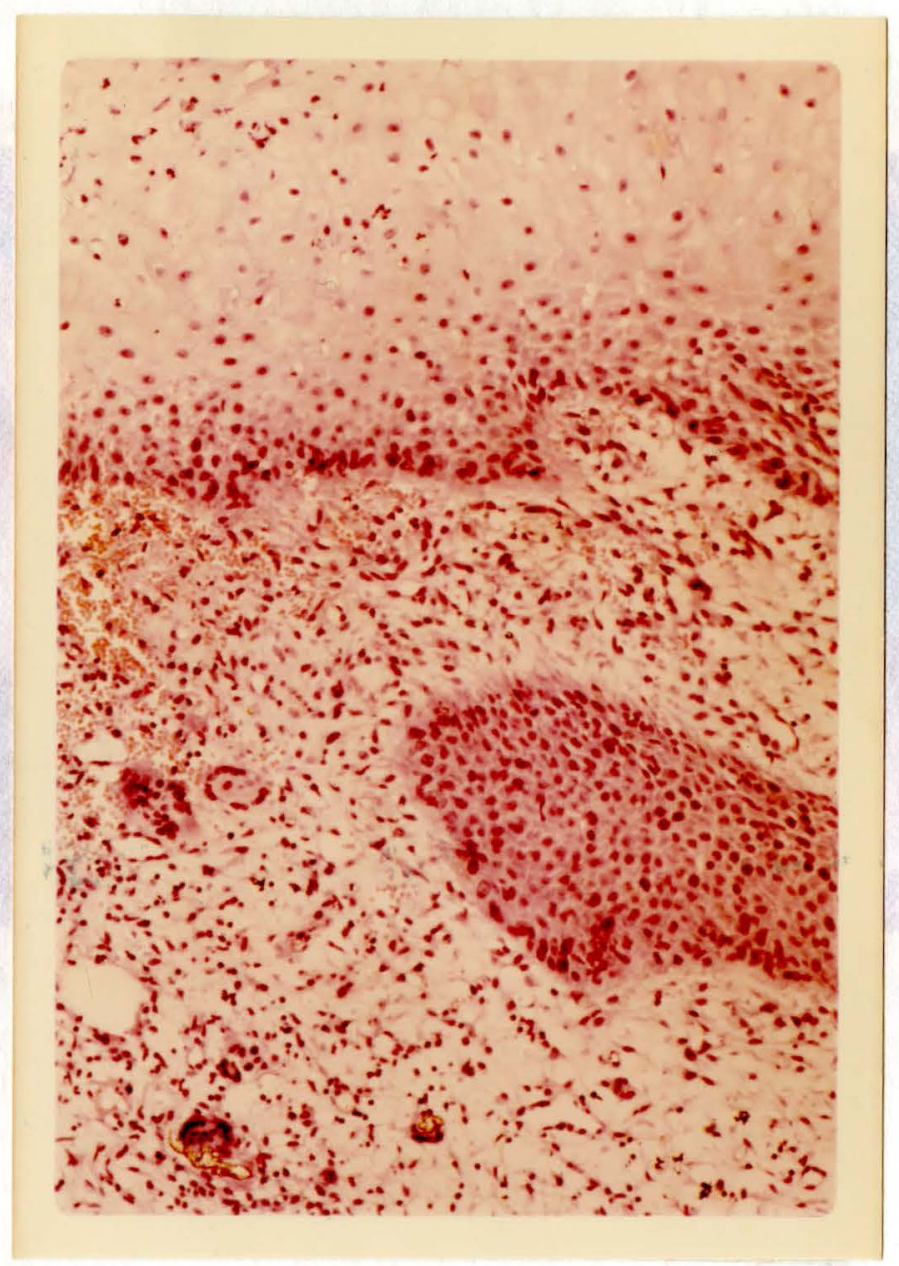




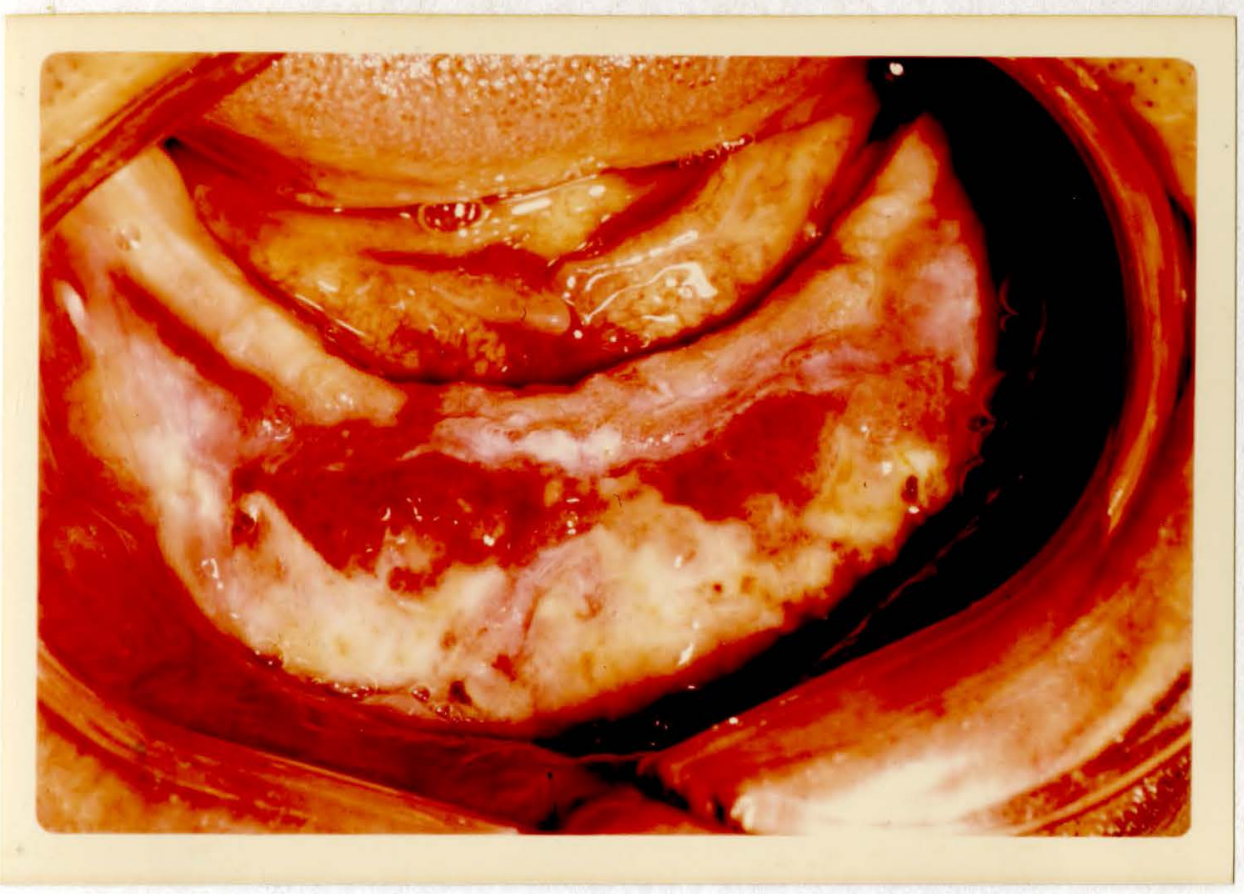

\author{
P1s. 15 \\ 9 day grart \\ Note: areas of \\ cranulation tissue
}




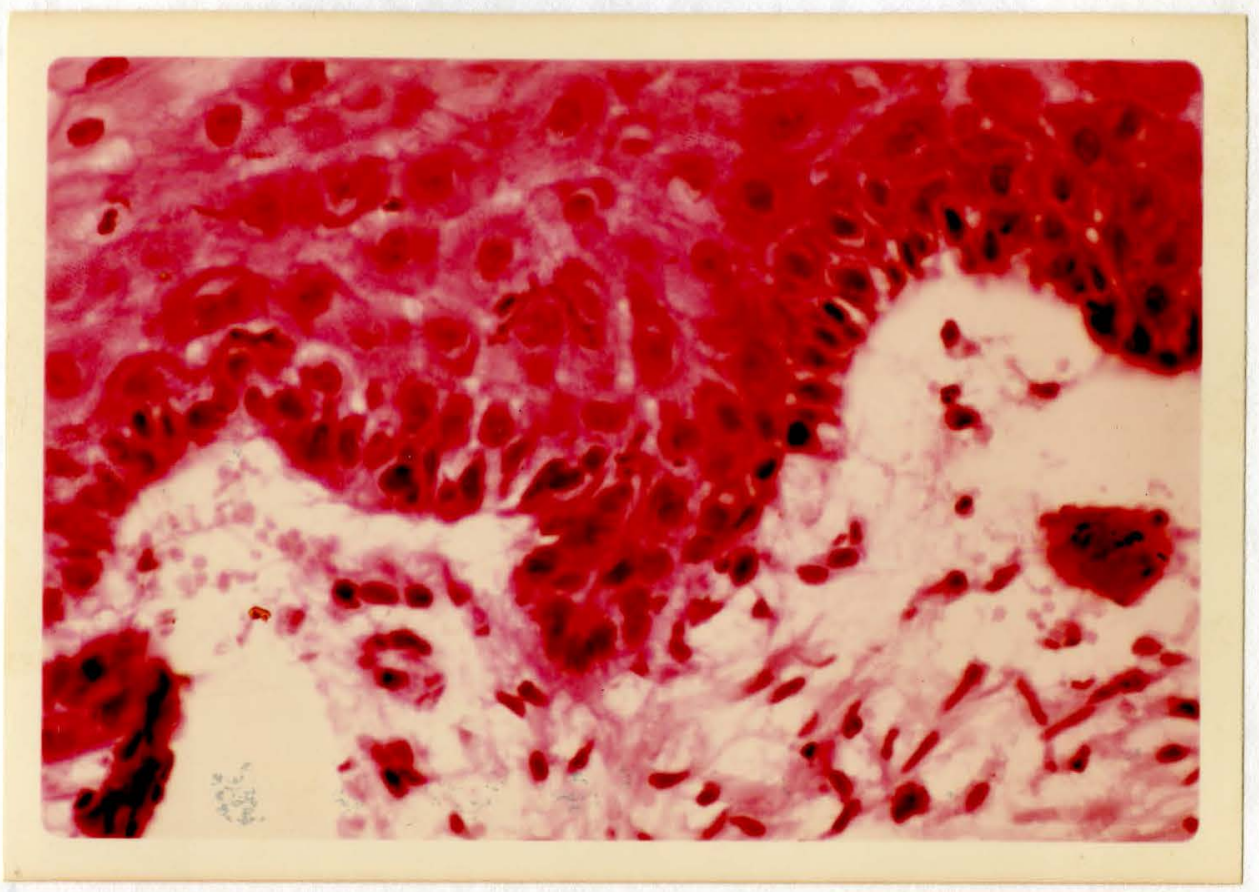

FIg. 16

10 day biopsy (250x)

Note: mitotic activity in

basal layer 


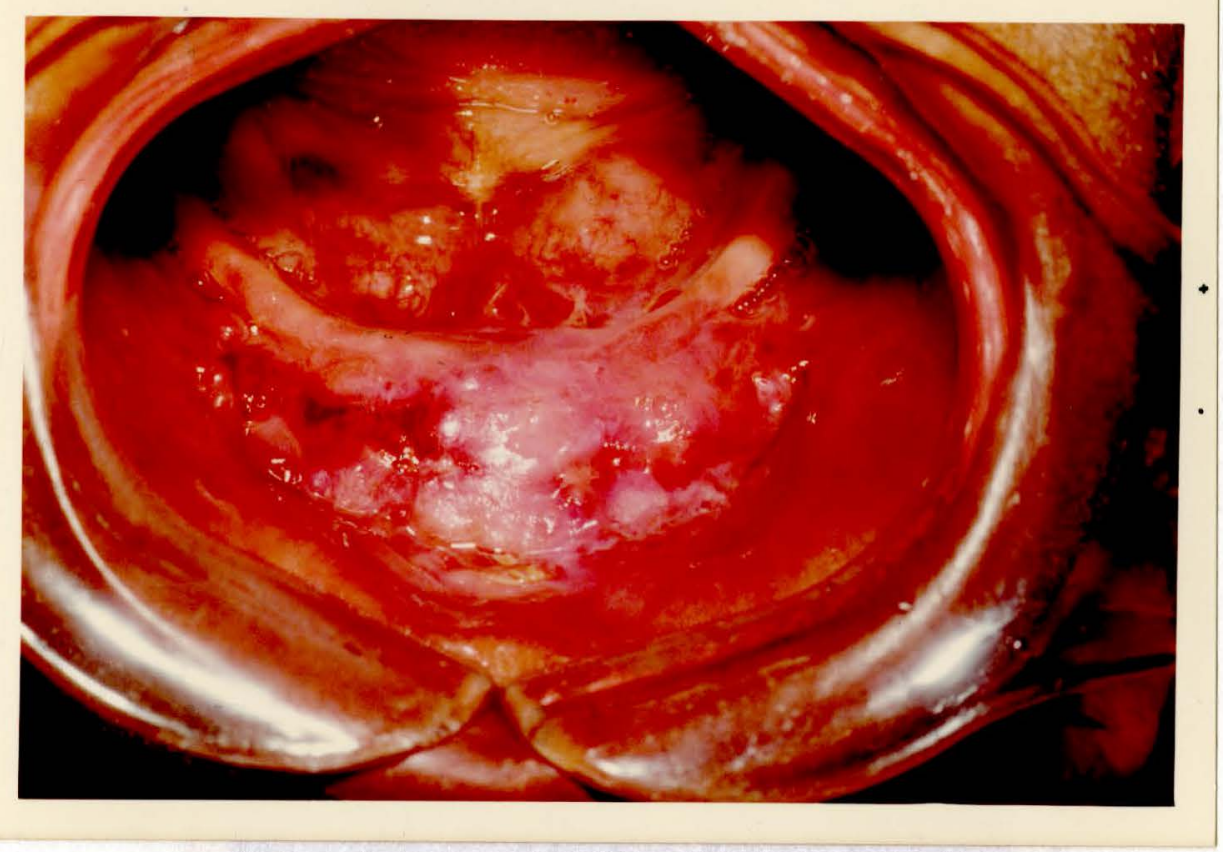

81.5. 17

12 day graft 


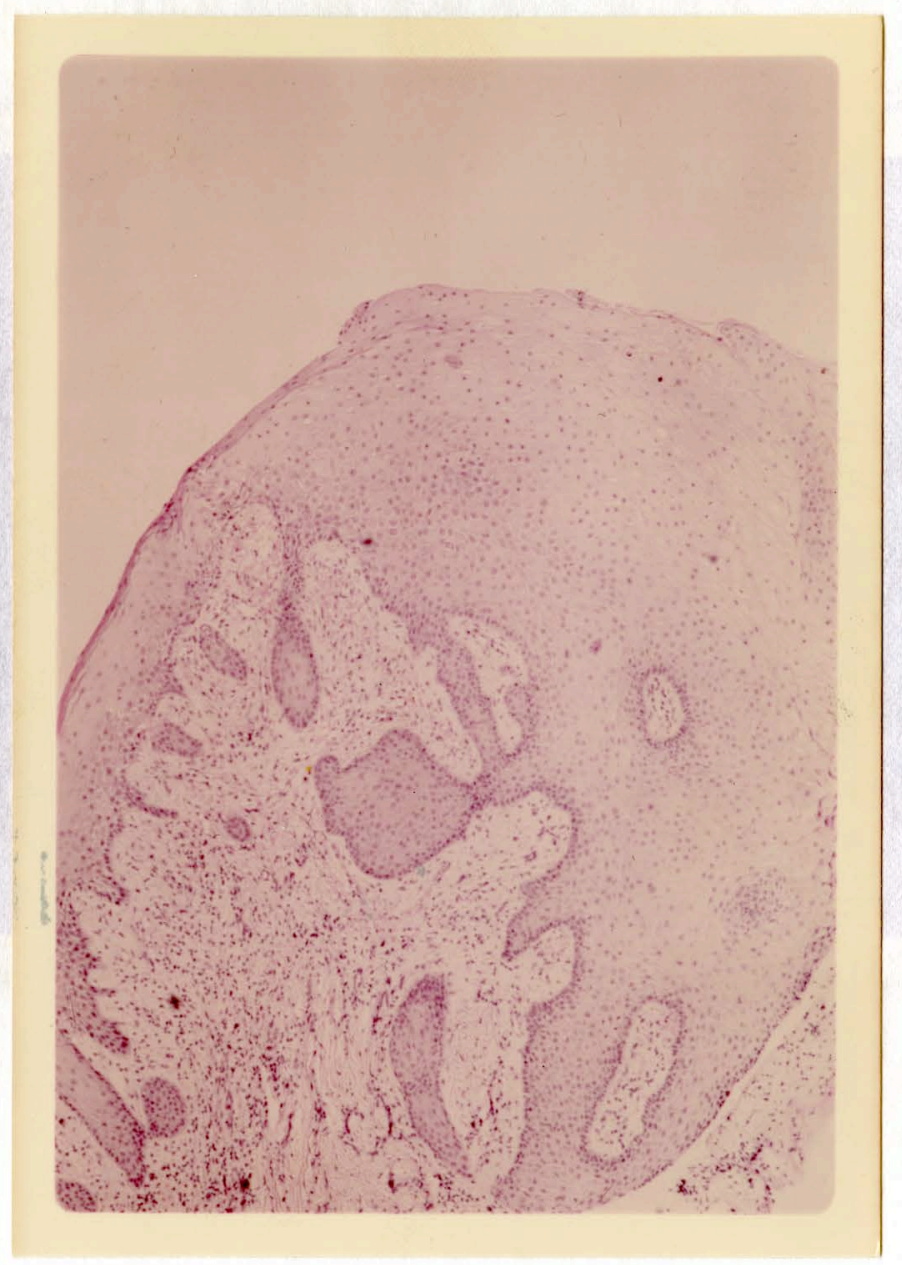

PIS. 18

12 day blopay (40x)

Notes Intracel.ular eảeme

and widening of 1ntracellular spaces 


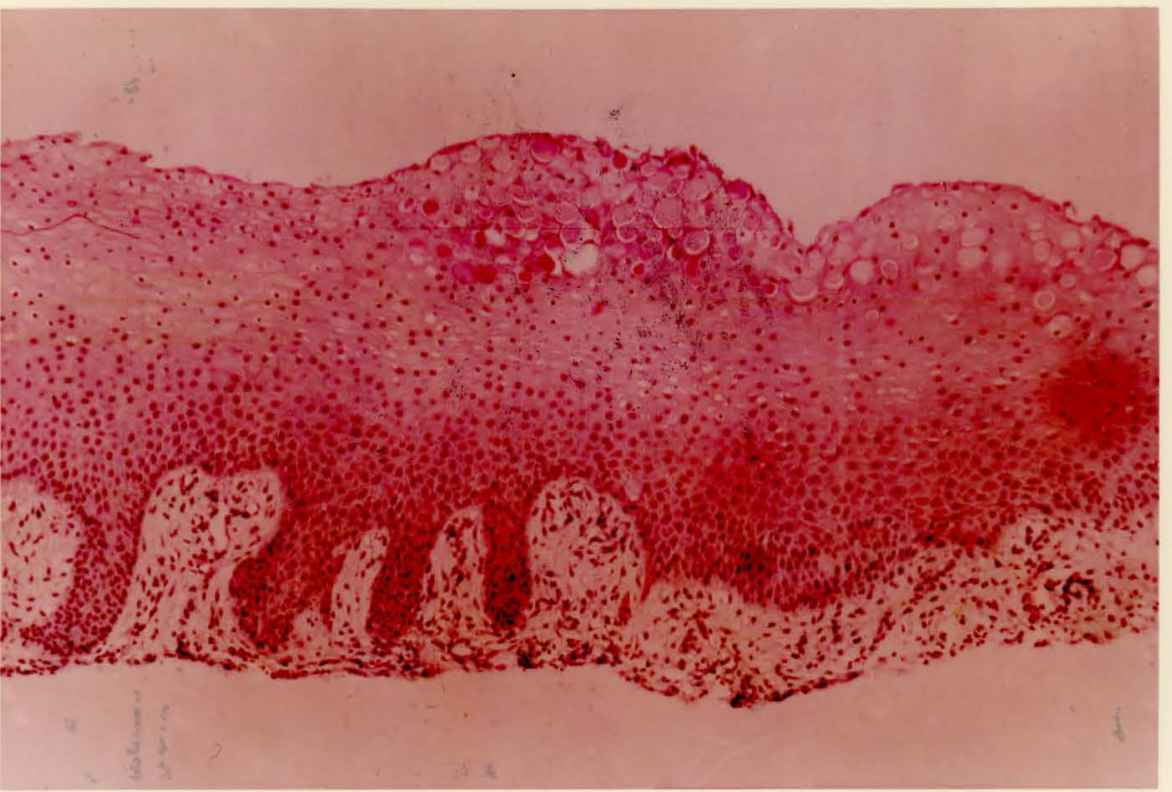

PL. 19

14 day biopsy (40x)

Notes larce globules of eosinophlite material In Immature eplthelium 


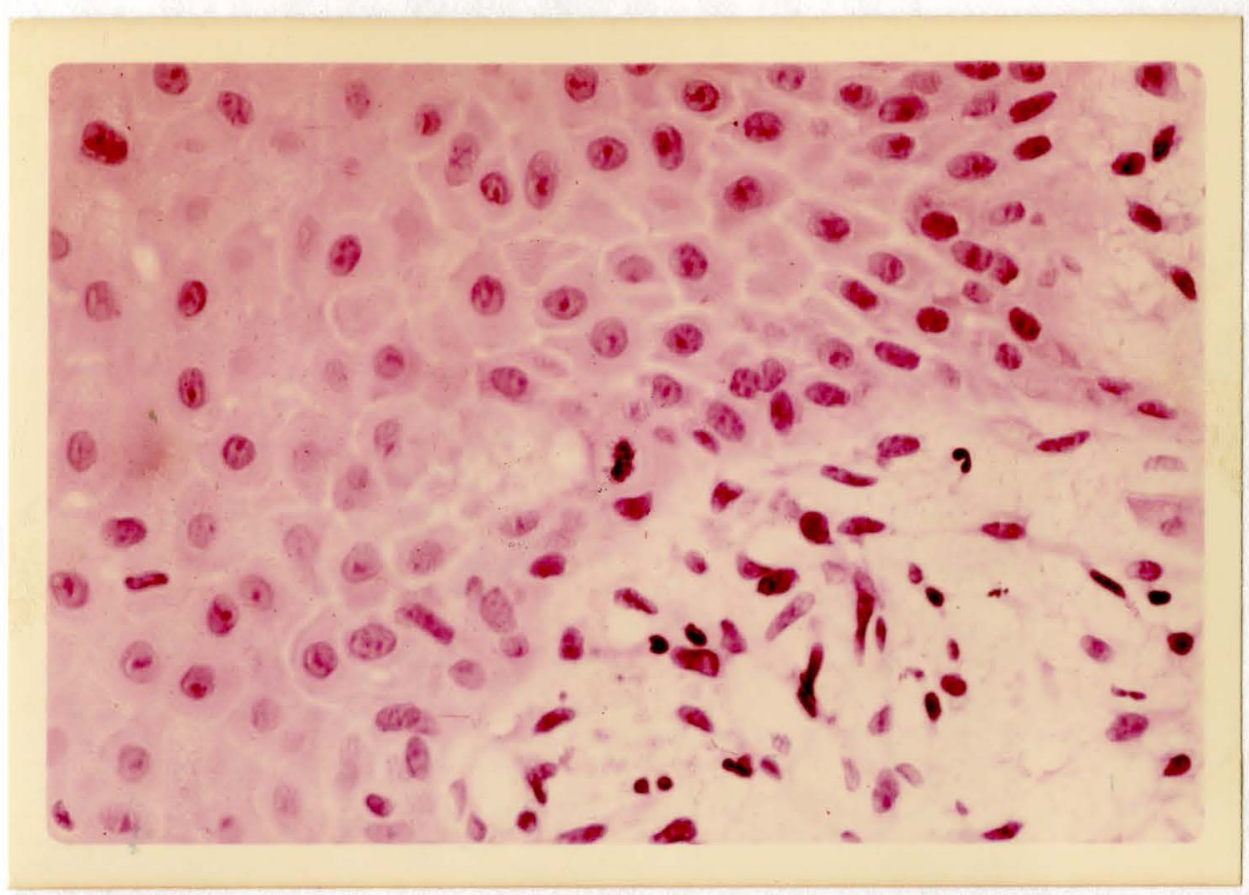

\author{
Dis. 20 \\ 14 day biopsy (250x) \\ Notes mitotio activity \\ In basal coll layor
}




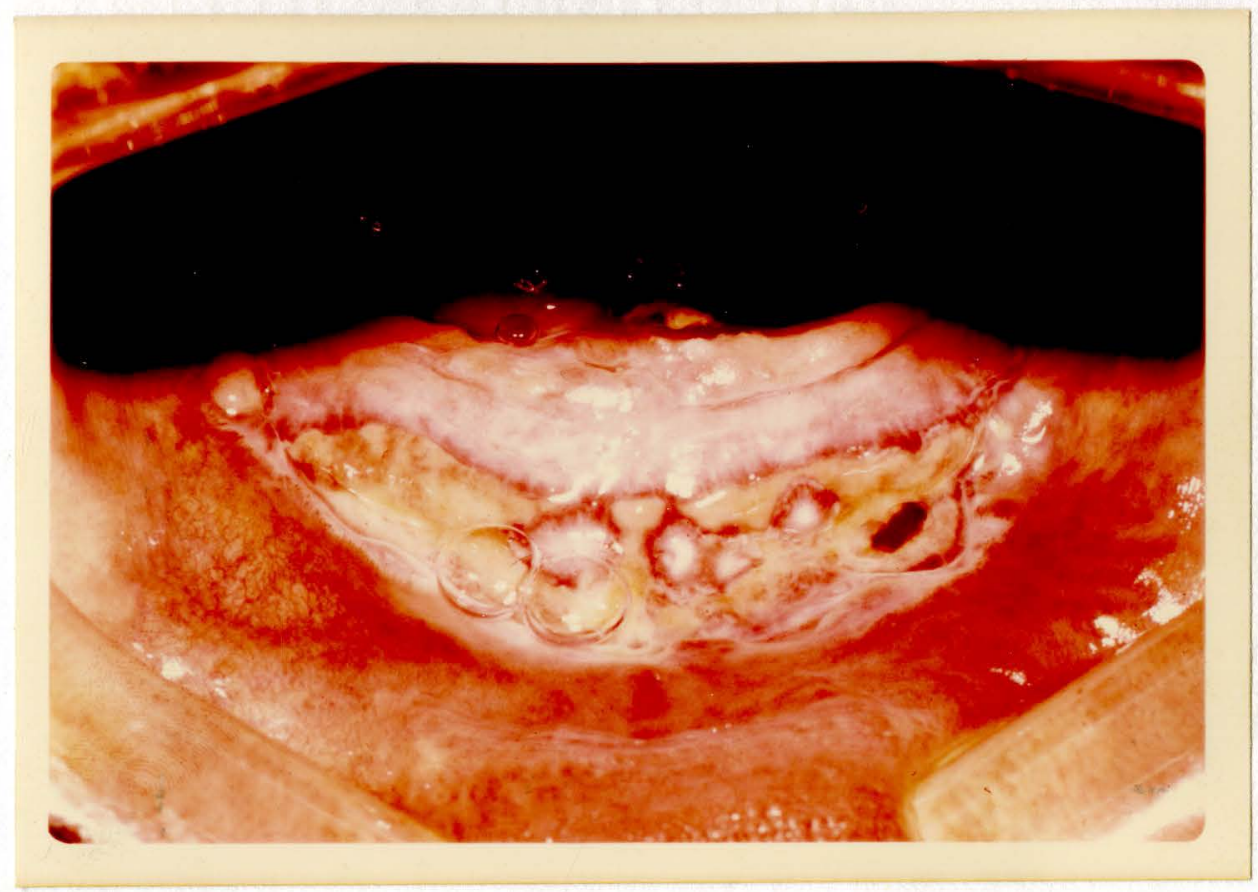

EIE. 21

15 day sraft

Notes areas of mranulation

tissuc about cxart 


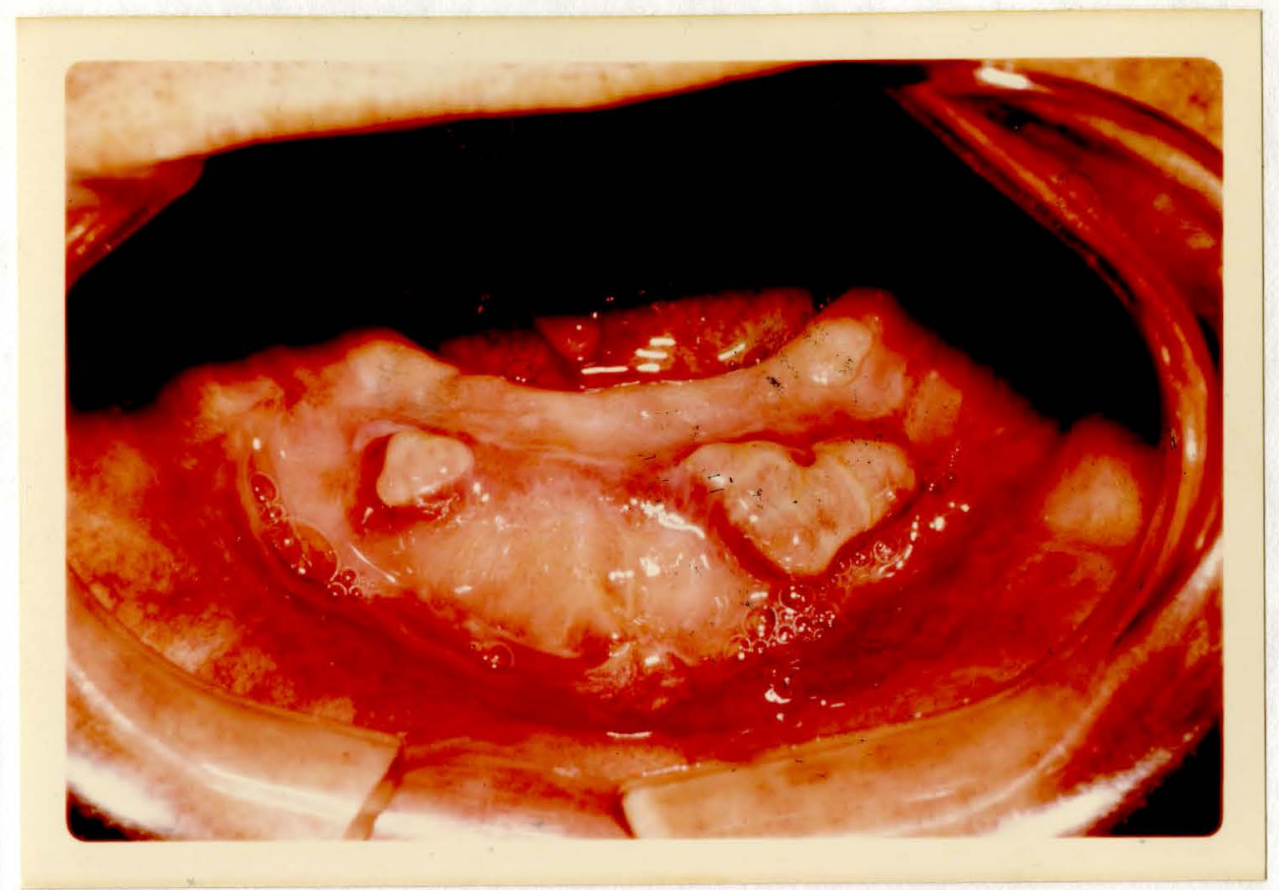

13. 22

19 day traft

Note: blebs of

eranulation tissue 


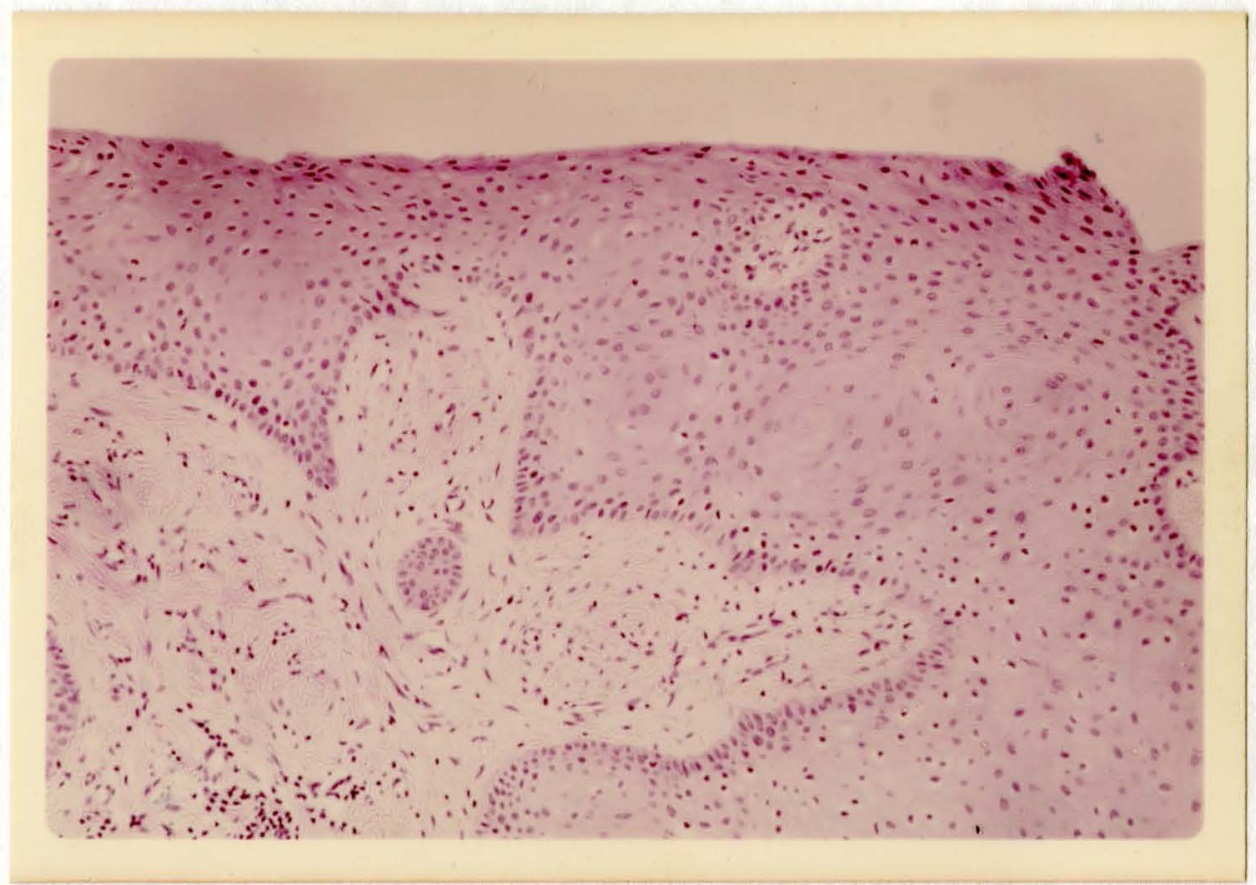

FIE. 23

19 day blogey (1.00x)

Note: mild ayskeratosis and intracellular edema. 


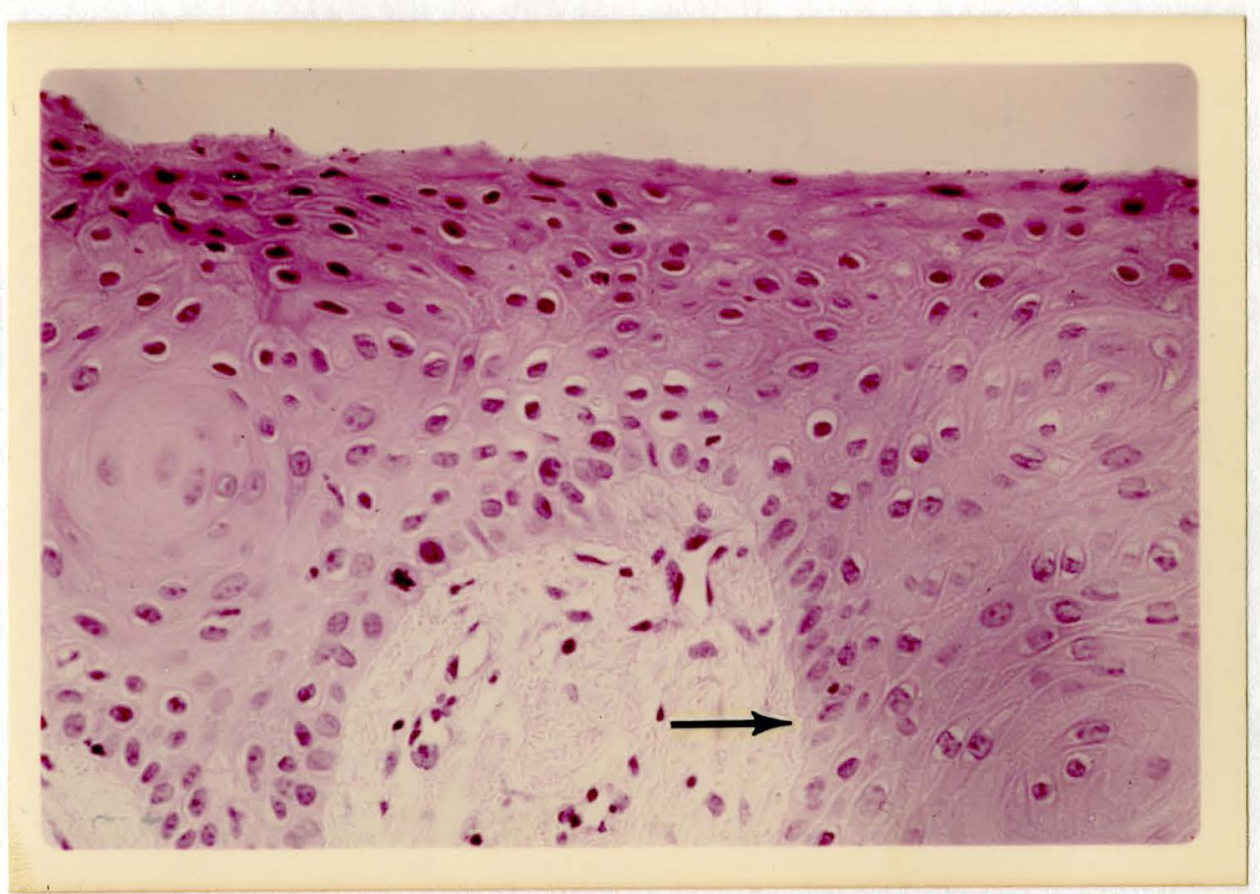

Fic. 24

19 day blopsy (250x)

Note: axeas where basal

Lanine appears to "dip" between besal cells (arrow) 


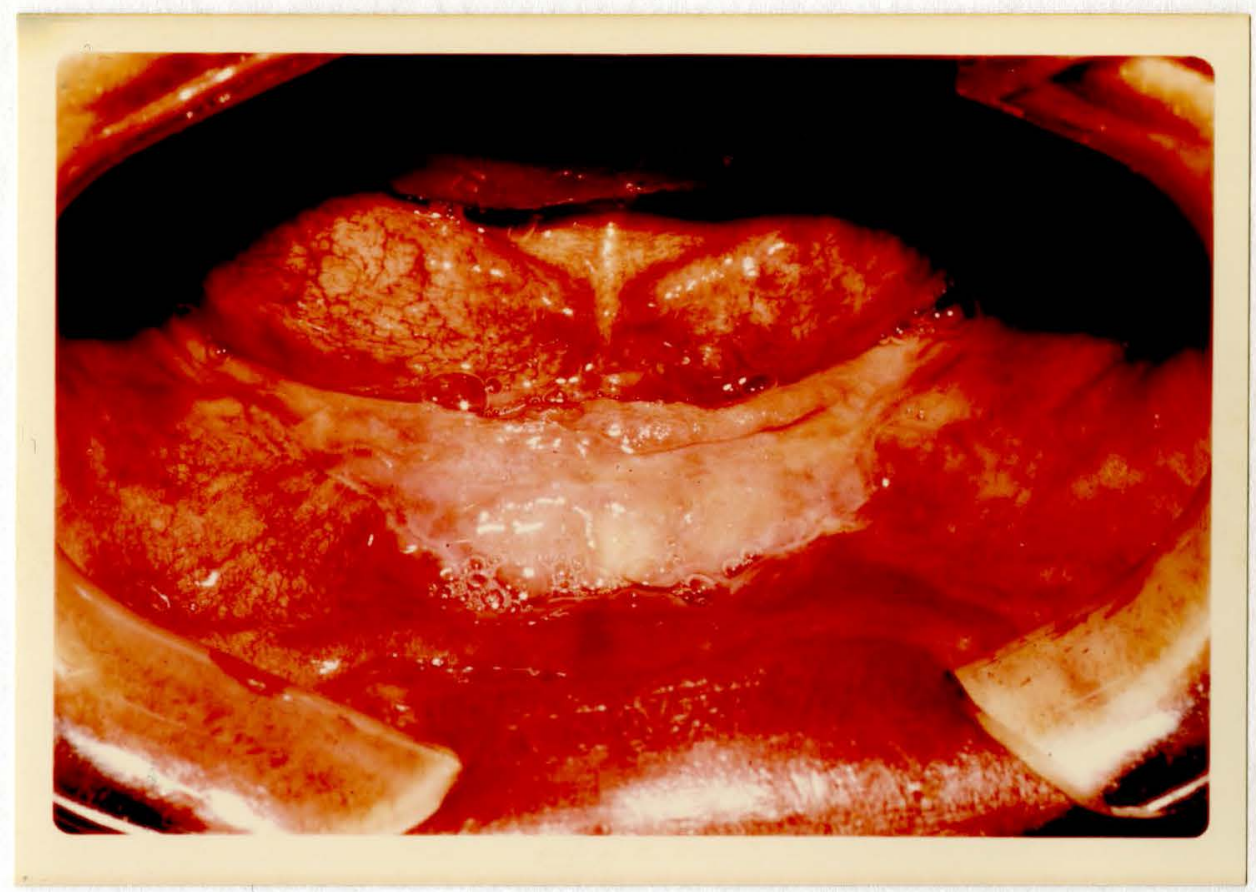

Fis. 25

23 day exart

Note a graft tissue is

blended well into the

surround line oral mucosa 


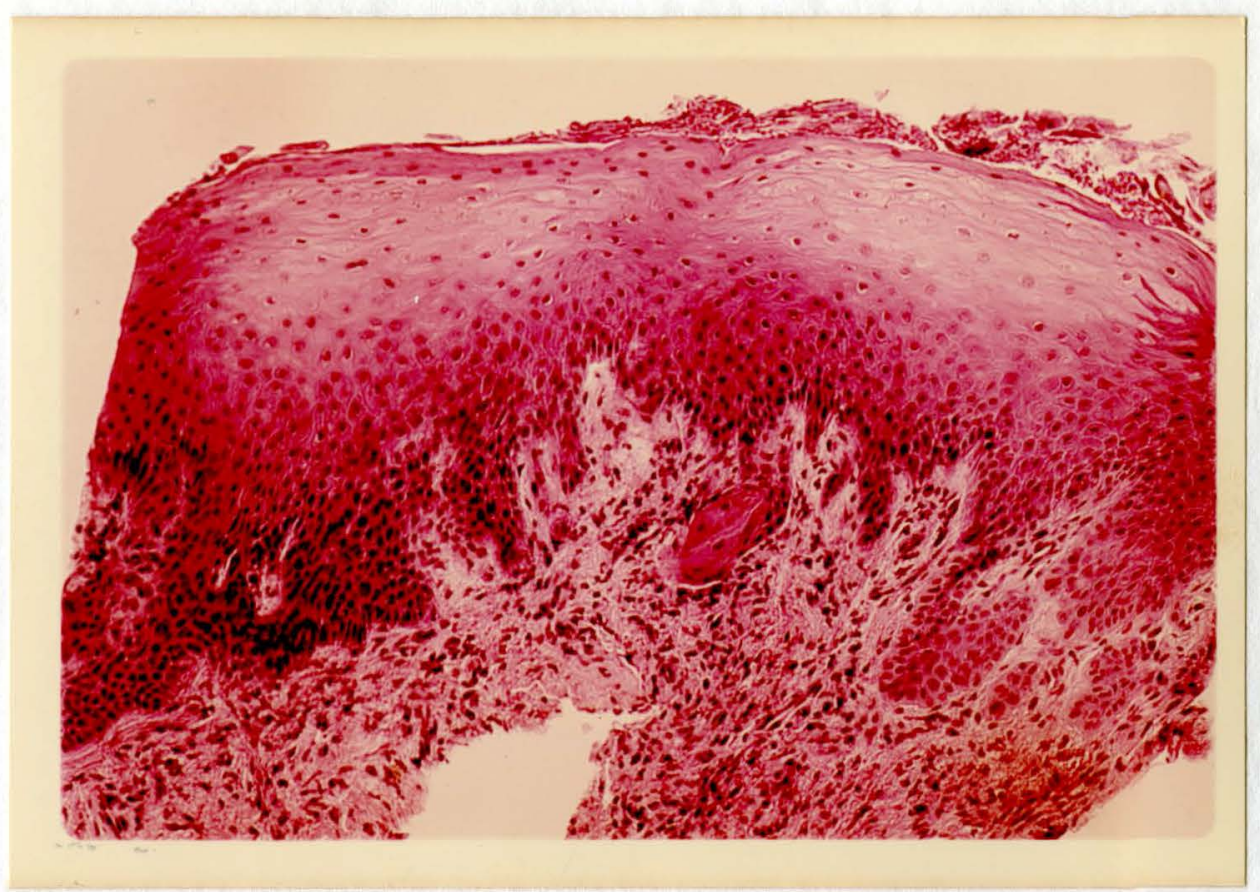

\author{
Plg. 26 \\ 23 day biopsy (100x) \\ Note: sone perimuclear edena \\ stili evident and numerous \\ mitotic figures in basal. layer
}




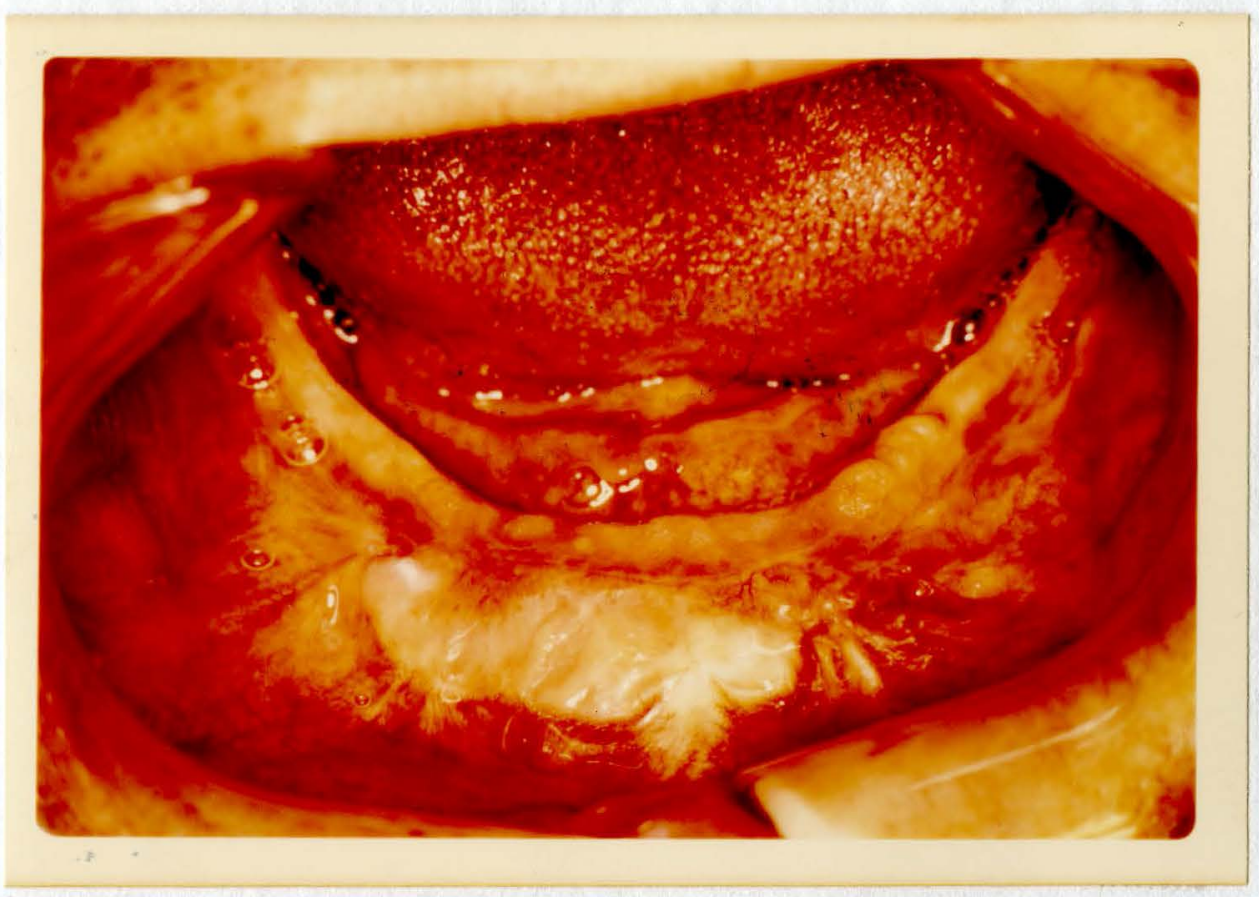

\author{
Fis. 27 \\ 30 day graft \\ Note: palatal rugao for- \\ mation in grafted tisave
}




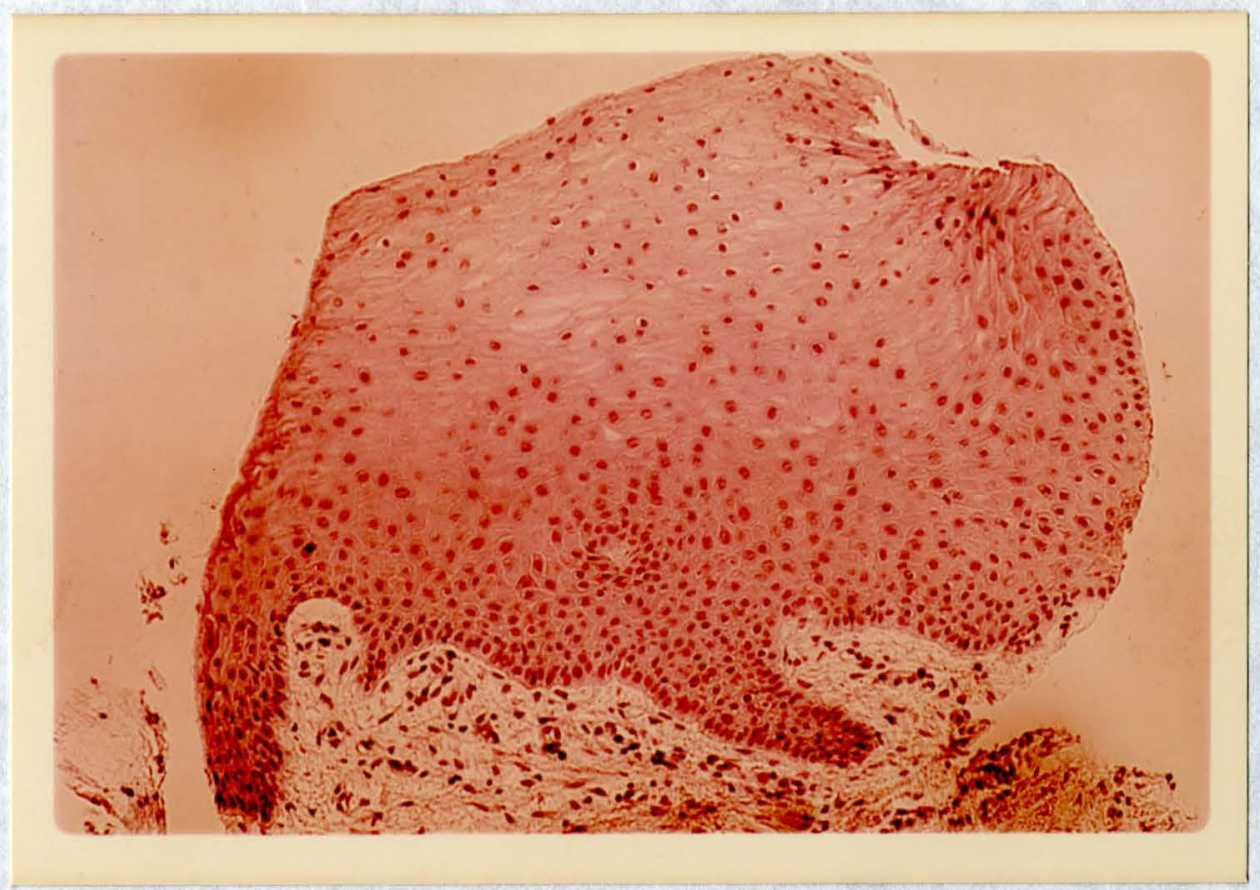

F15. 28

30 day blopsy (100x)

Notes norma? appearine epitheliun with parekeratosis of stratum corneum 


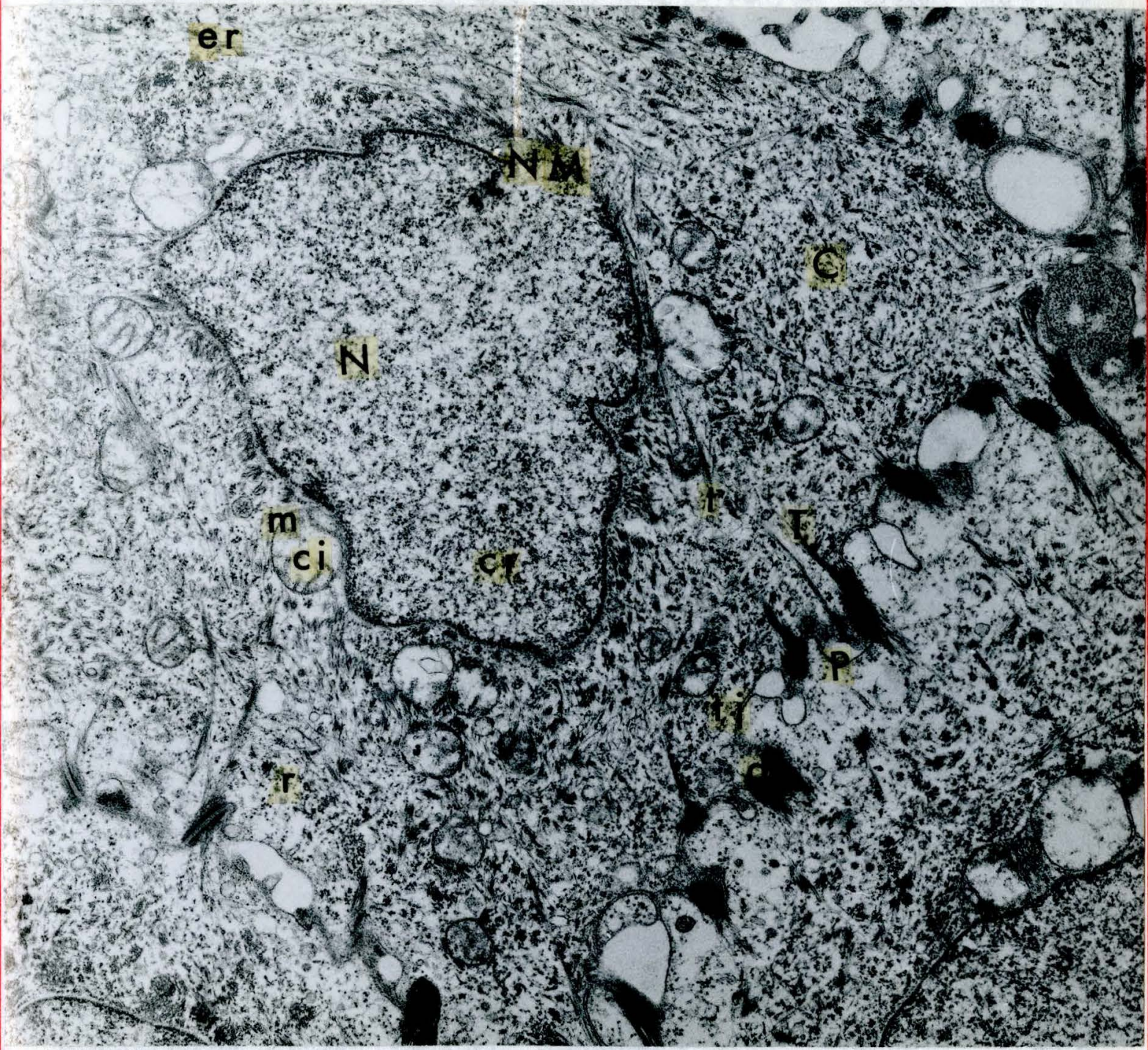

\section{Fis. 29}

0 day frosh biopsy $(16,800 x)$

S tratura spinosum 


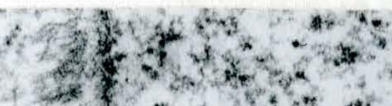

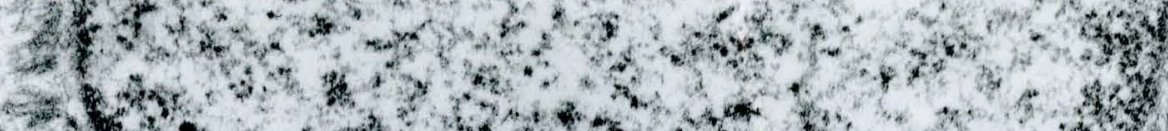

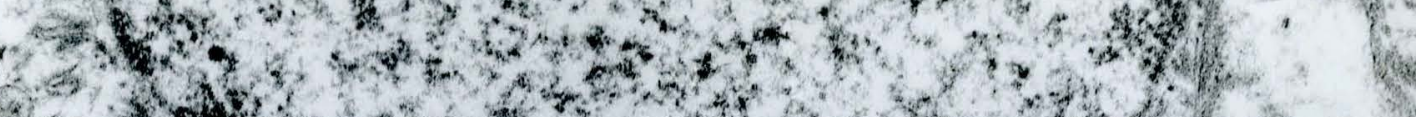

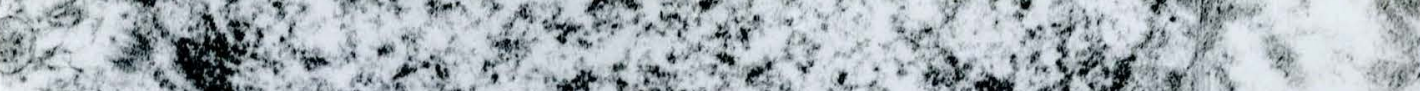

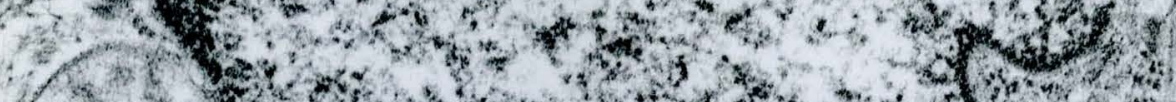

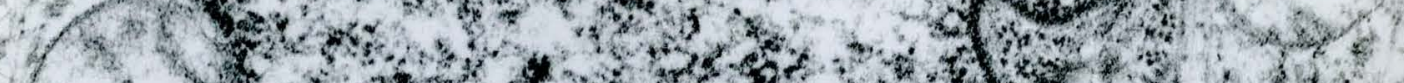

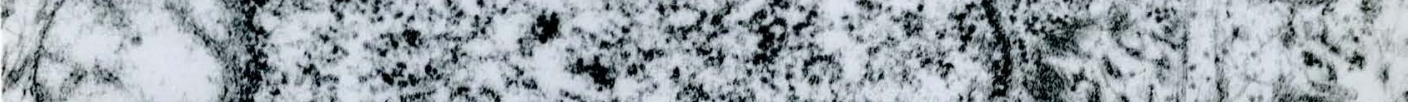

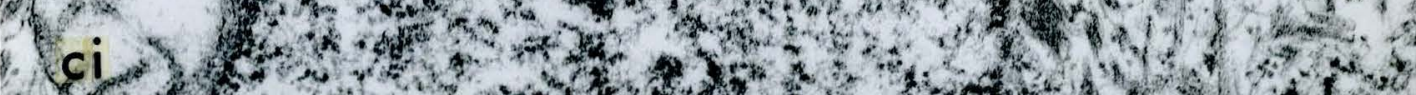

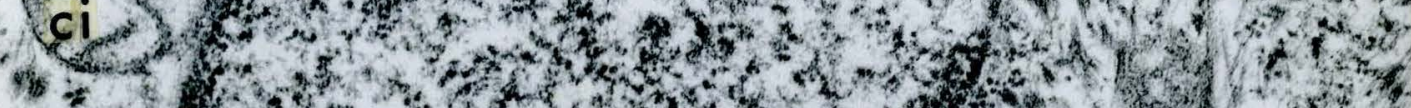

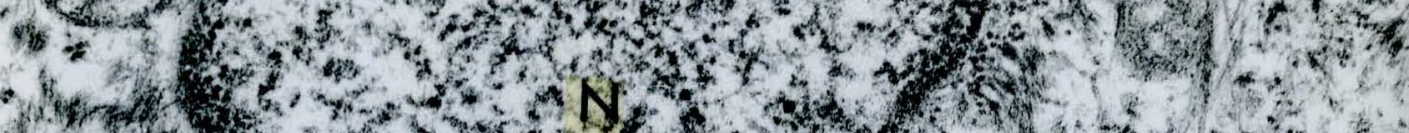

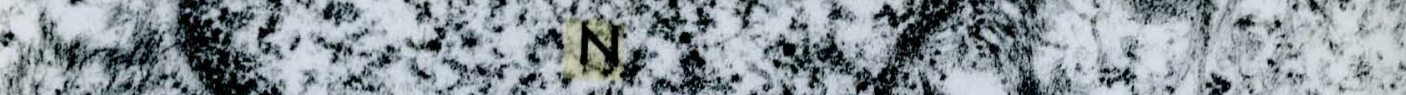

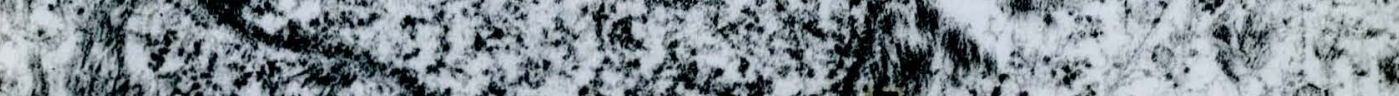

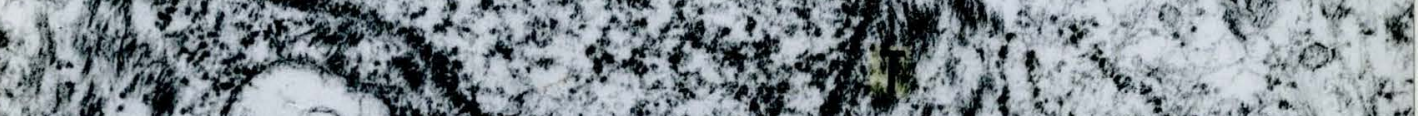

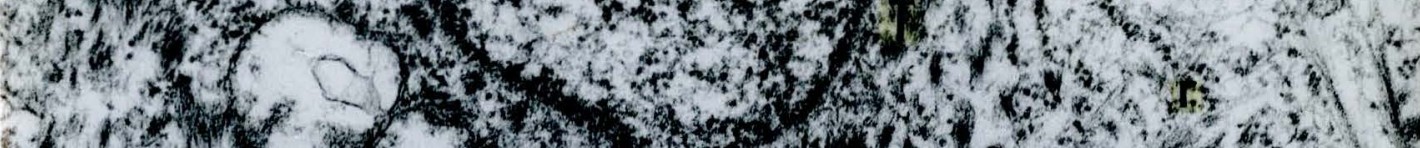

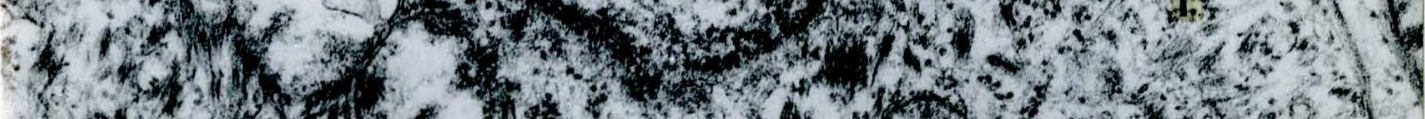

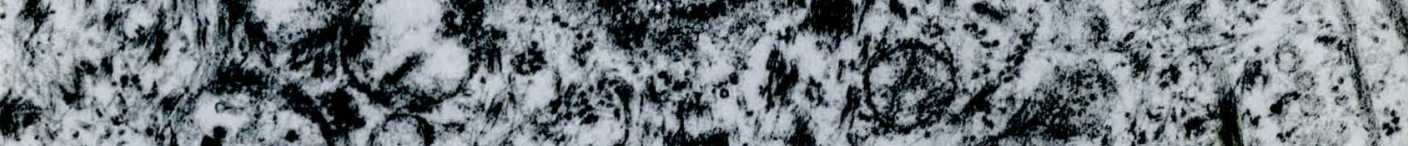

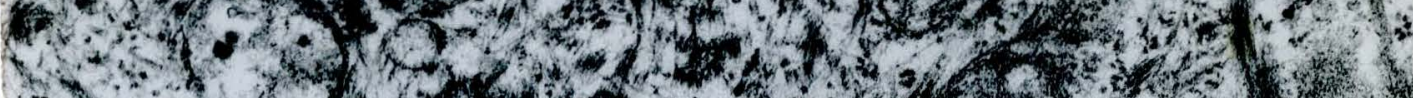

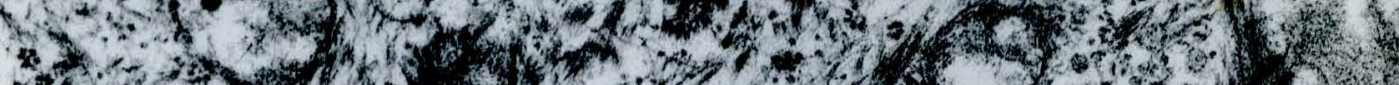

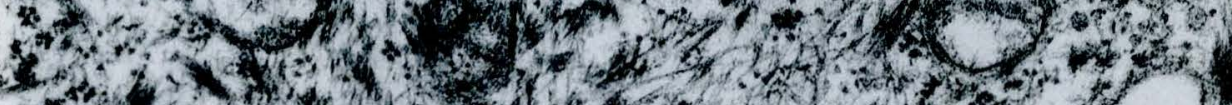

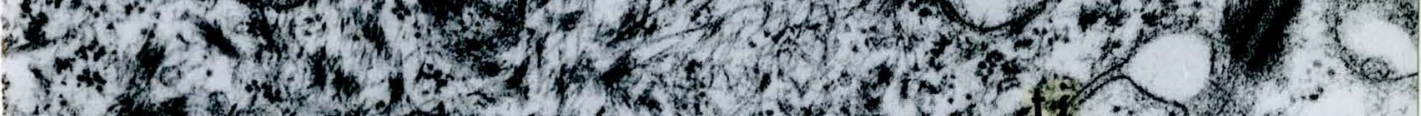

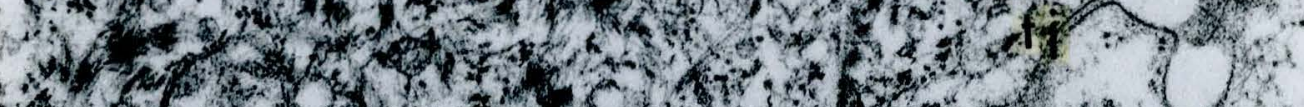

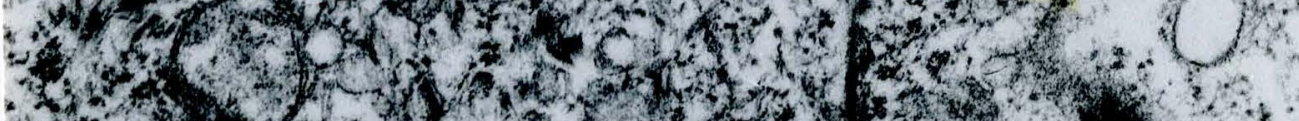

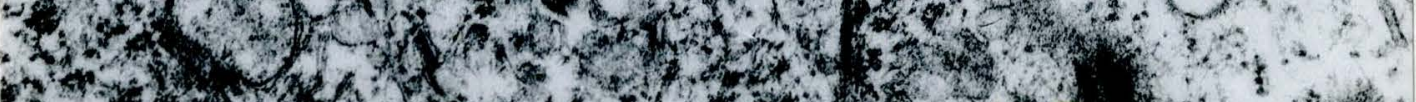

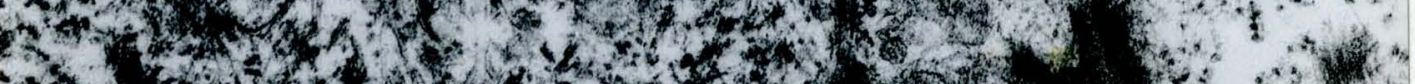

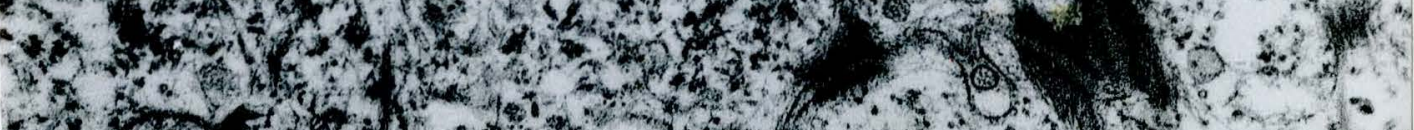

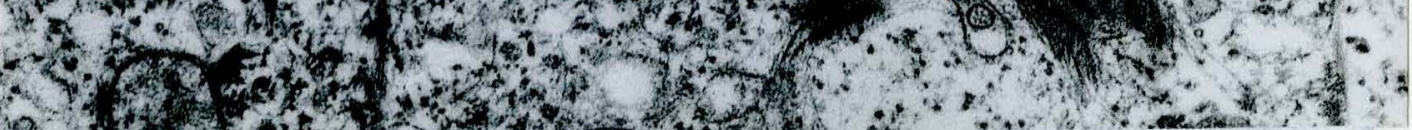

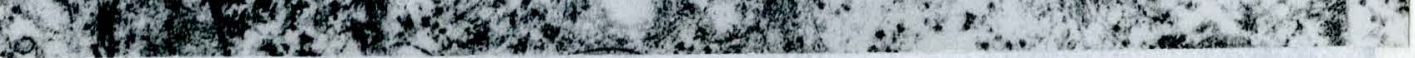

Fif. 30

0 day fresh bLopsy $(33,250 x)$

Stratum spinosum 


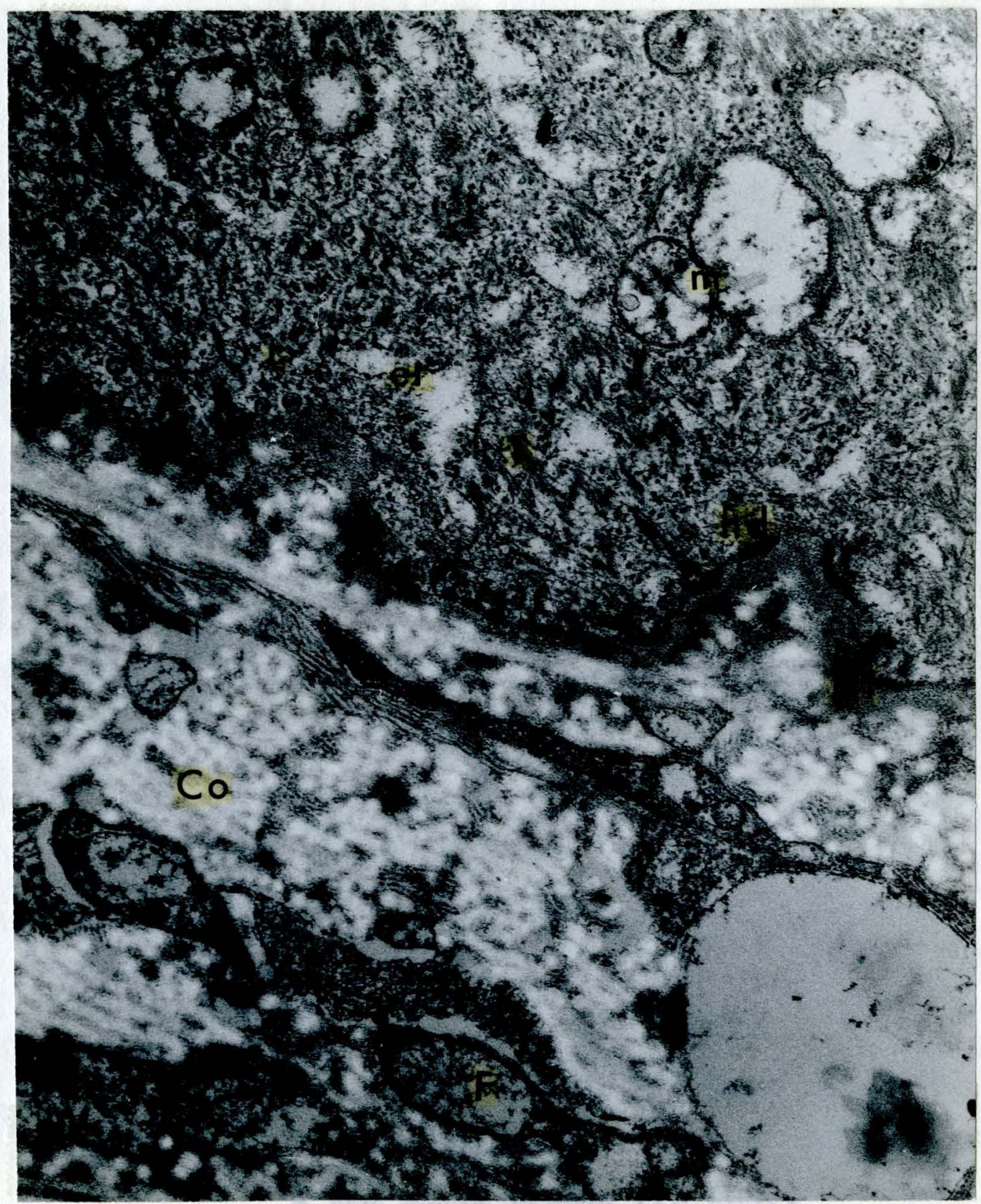

Fis. 31

0 day fresh biopsy $(33,250 x)$ Epithello-comnective tissue junction Note: well-defined basal lamina 


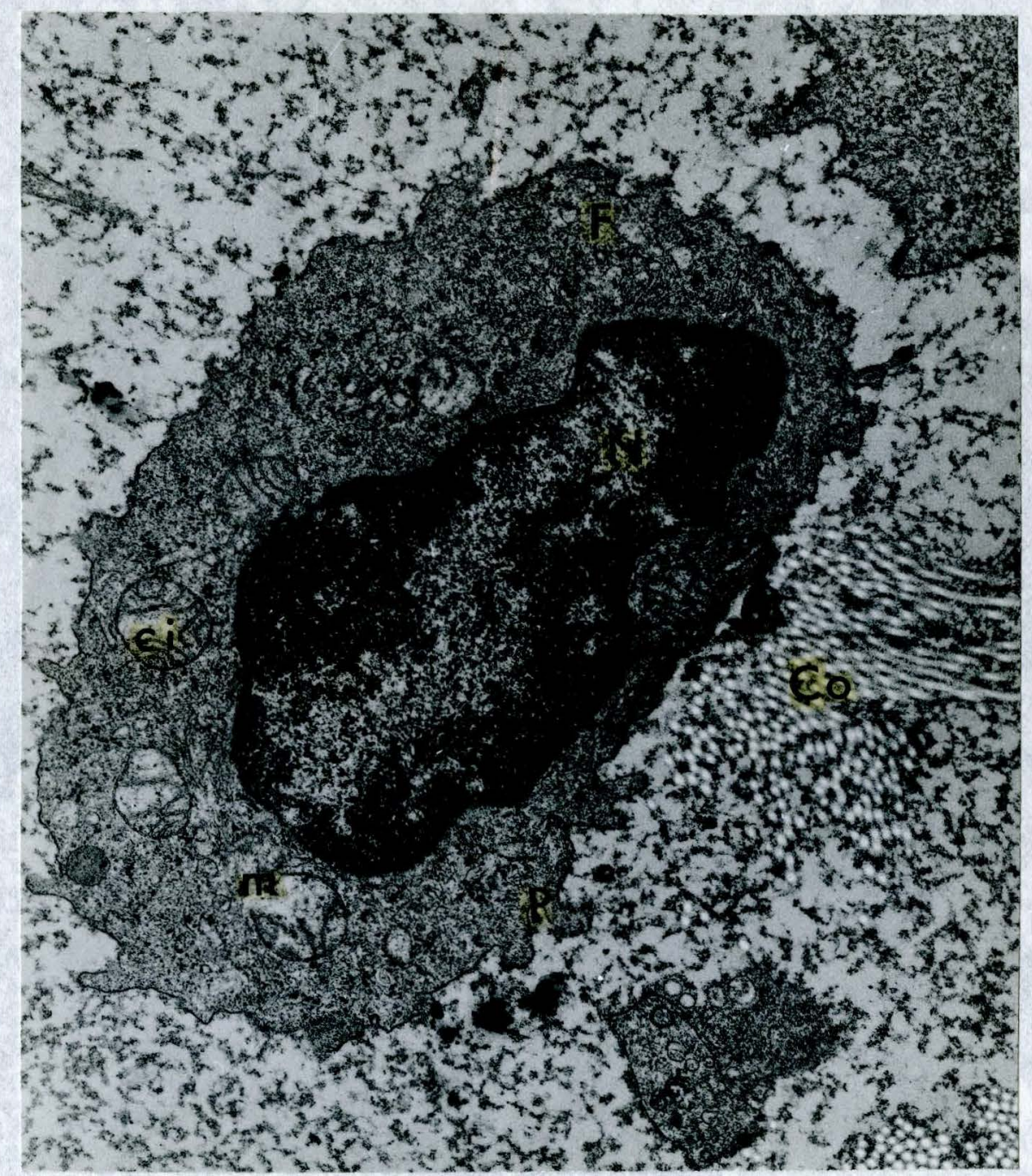

\section{Fis. 32}

o day fresh blopsy $(16,800 x)$

Ploroblast 


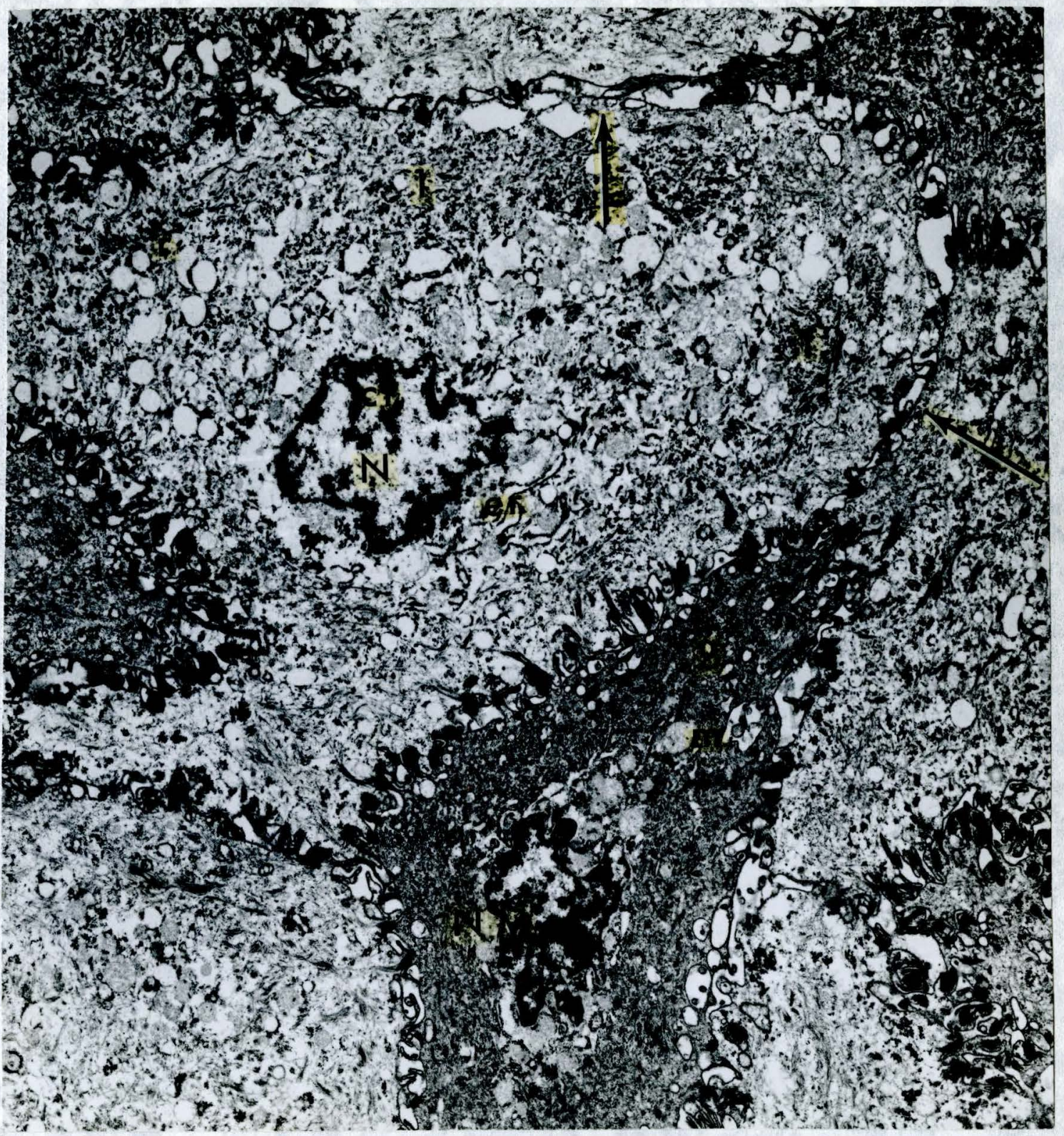

\subsection{3}

0 day post-frozen blopsy $(16,8000 x)$

\section{S tratur epinosum}

Note: difrerence in steining

quality between cells 1 and $/ 2$ 


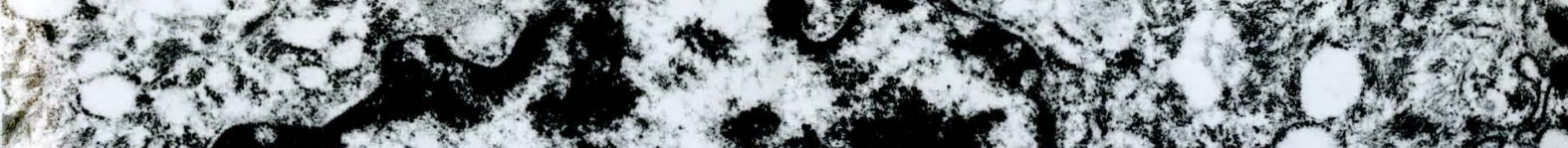

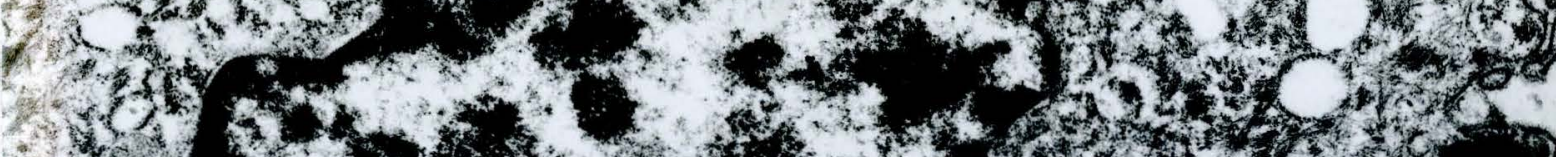

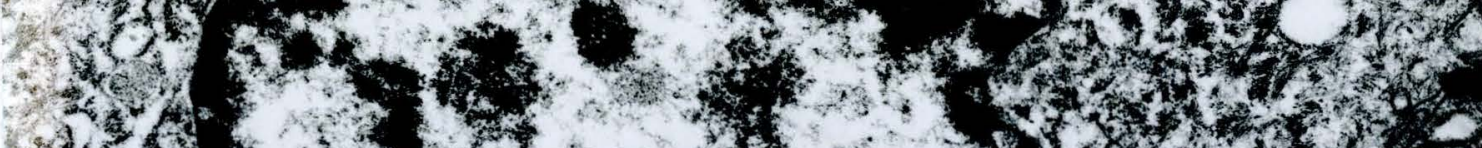

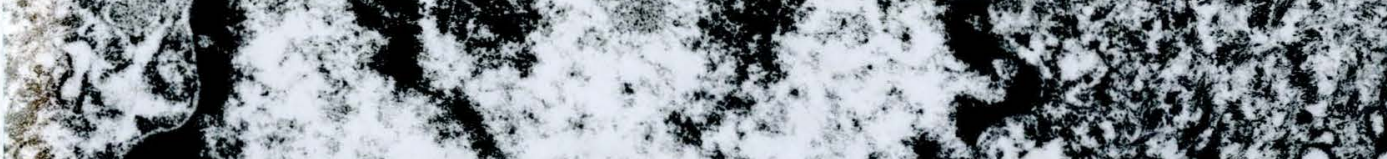

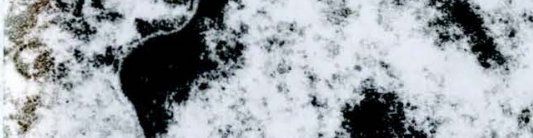

(1)

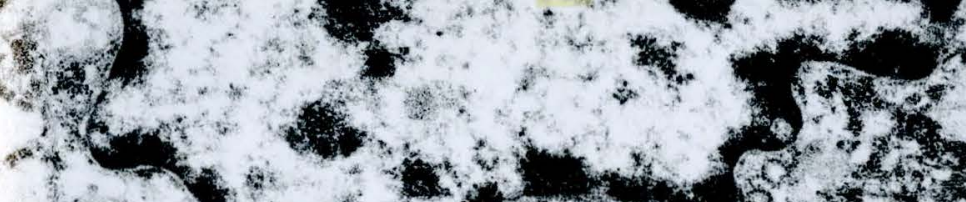

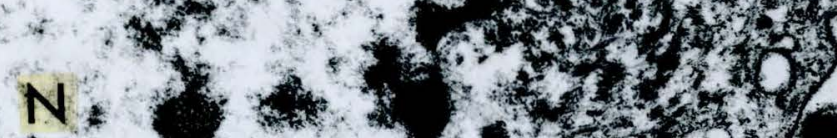

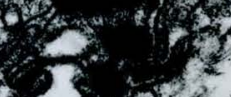

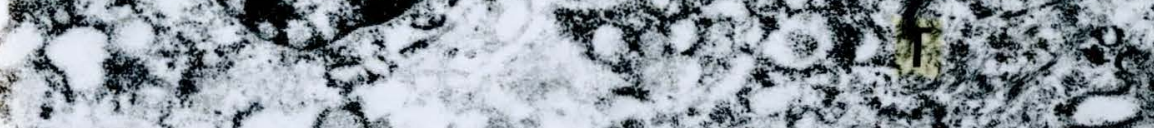

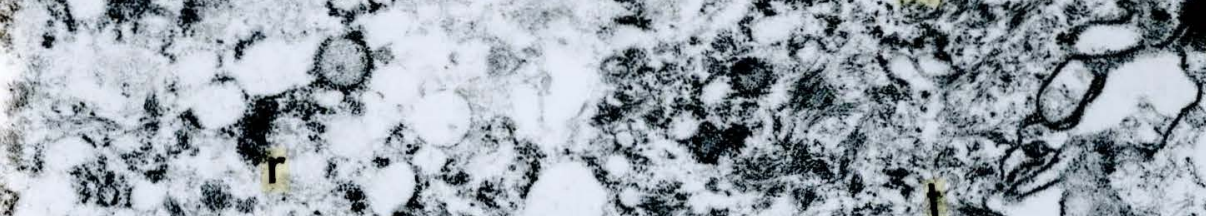

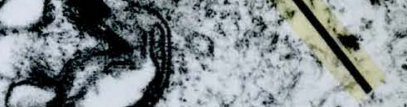

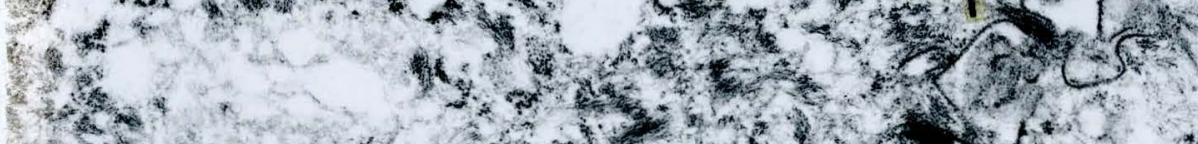

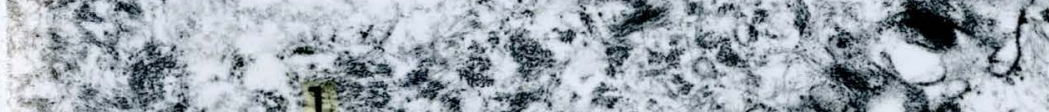

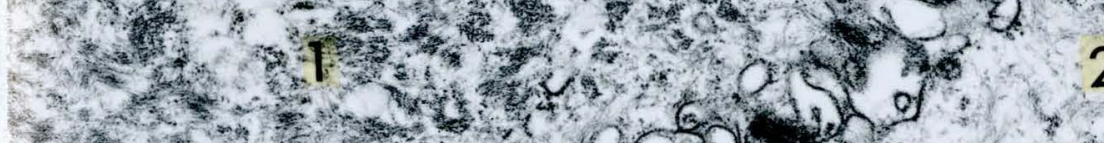

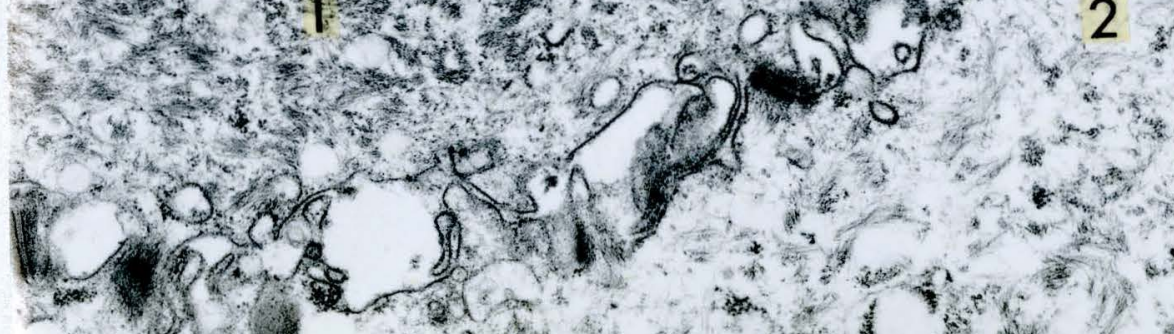

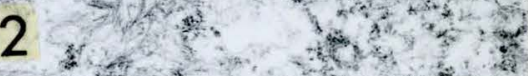

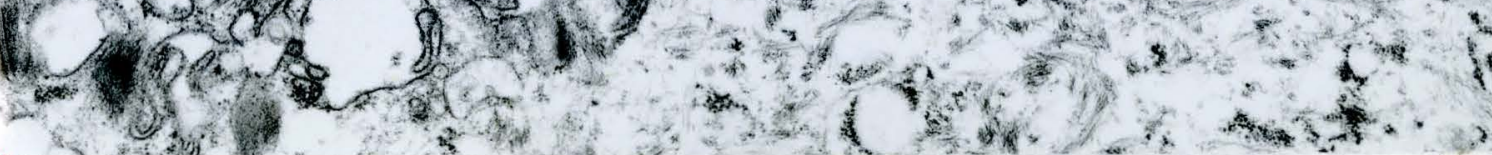

Fis. 34

0 day post-frozen biopsy $(33,250 x)$

Stratum spinosum

Note: clumping of chromatin

material and desmosomal degenera-

tion (arrow) 


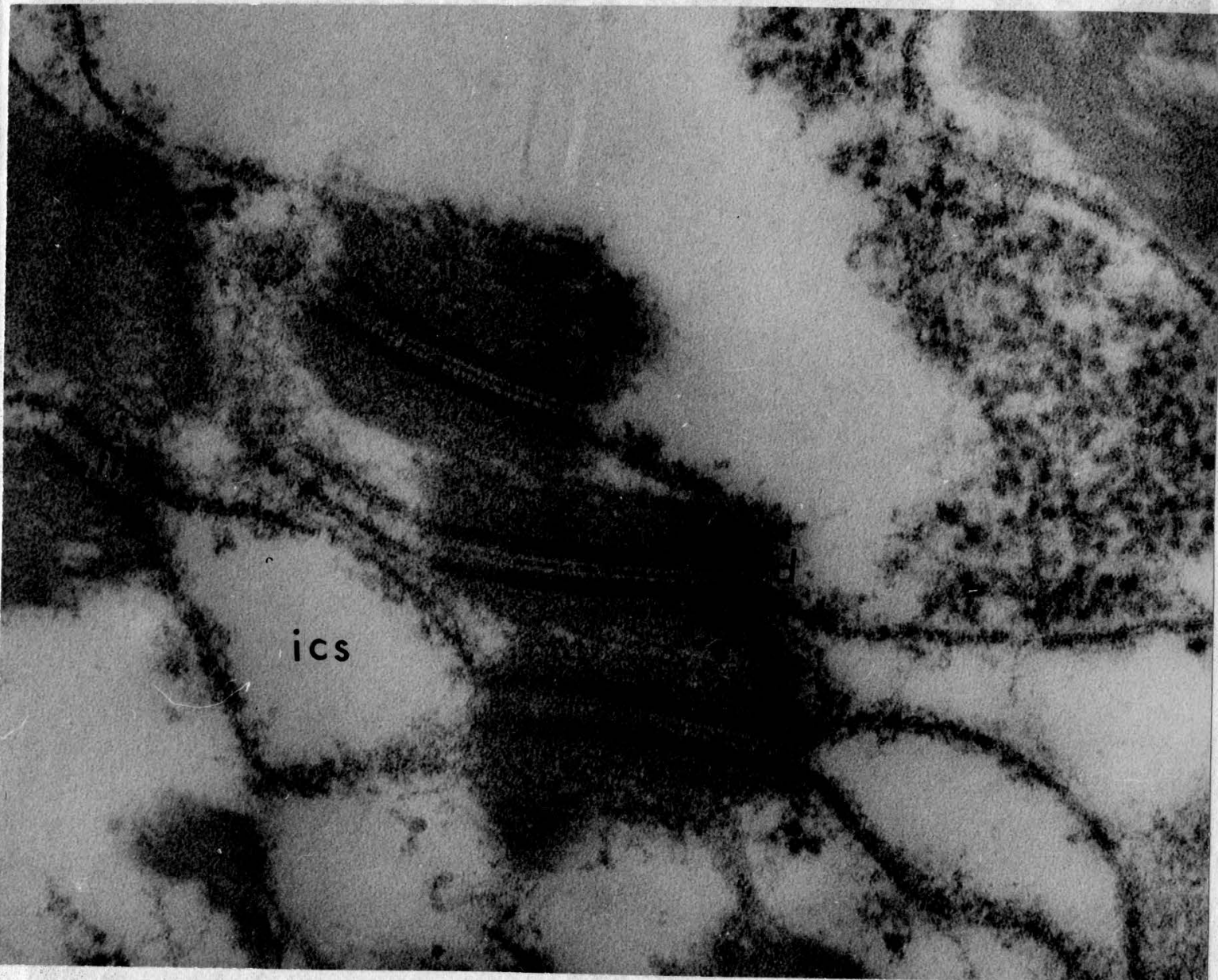

Fig. 35

0 day post-frozen biopsy $(98,000 x)$

Stratum spinosum

Note: highly ordered structure of desmosomes and tight junetton 


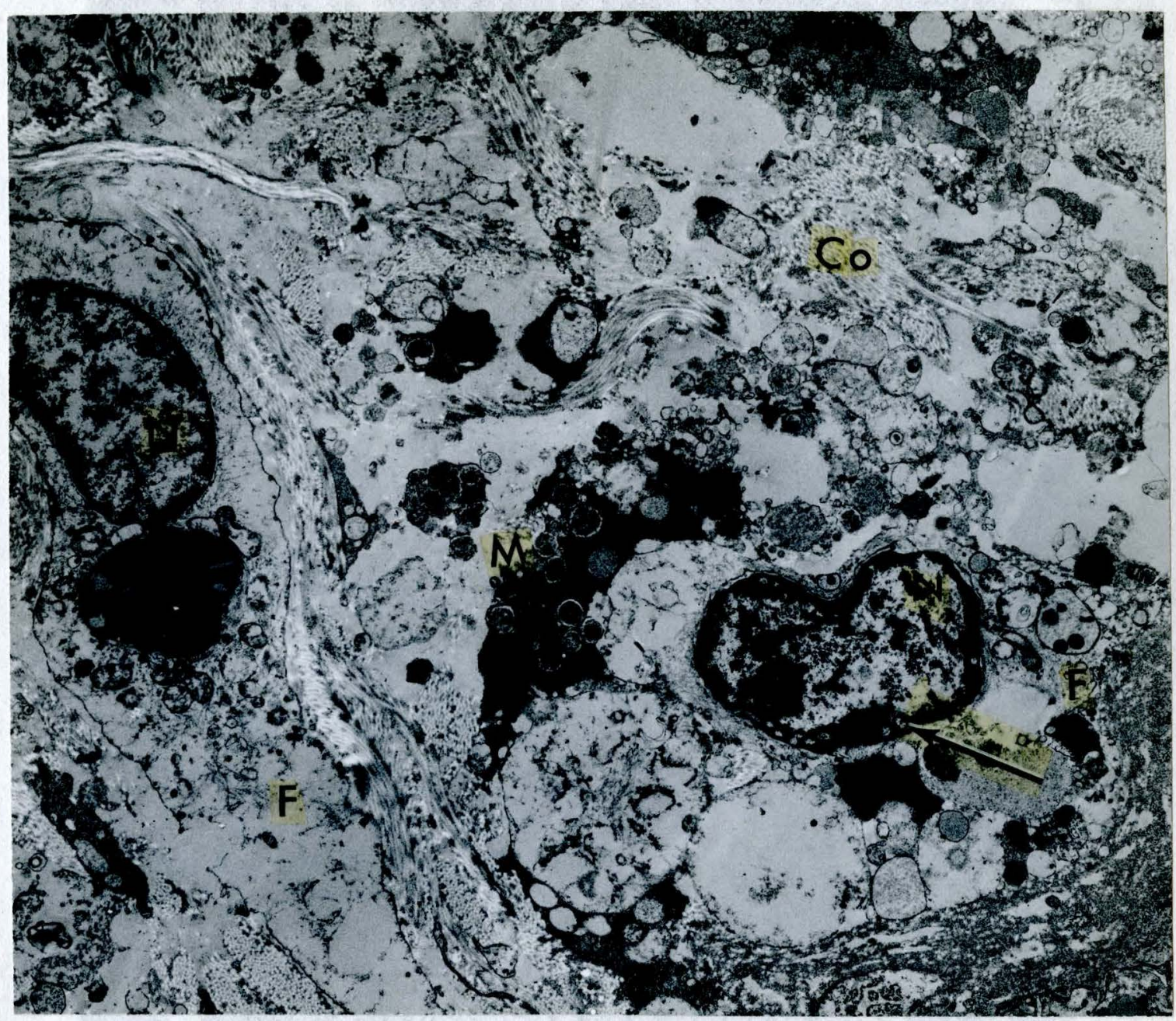

\section{Fig. 36}

0 day post-frozen biopsy $(6,650 x)$

Comnective tissue

Note: disrupted plasma menbranes of flbroblasts and remnants of macrophage (N) 


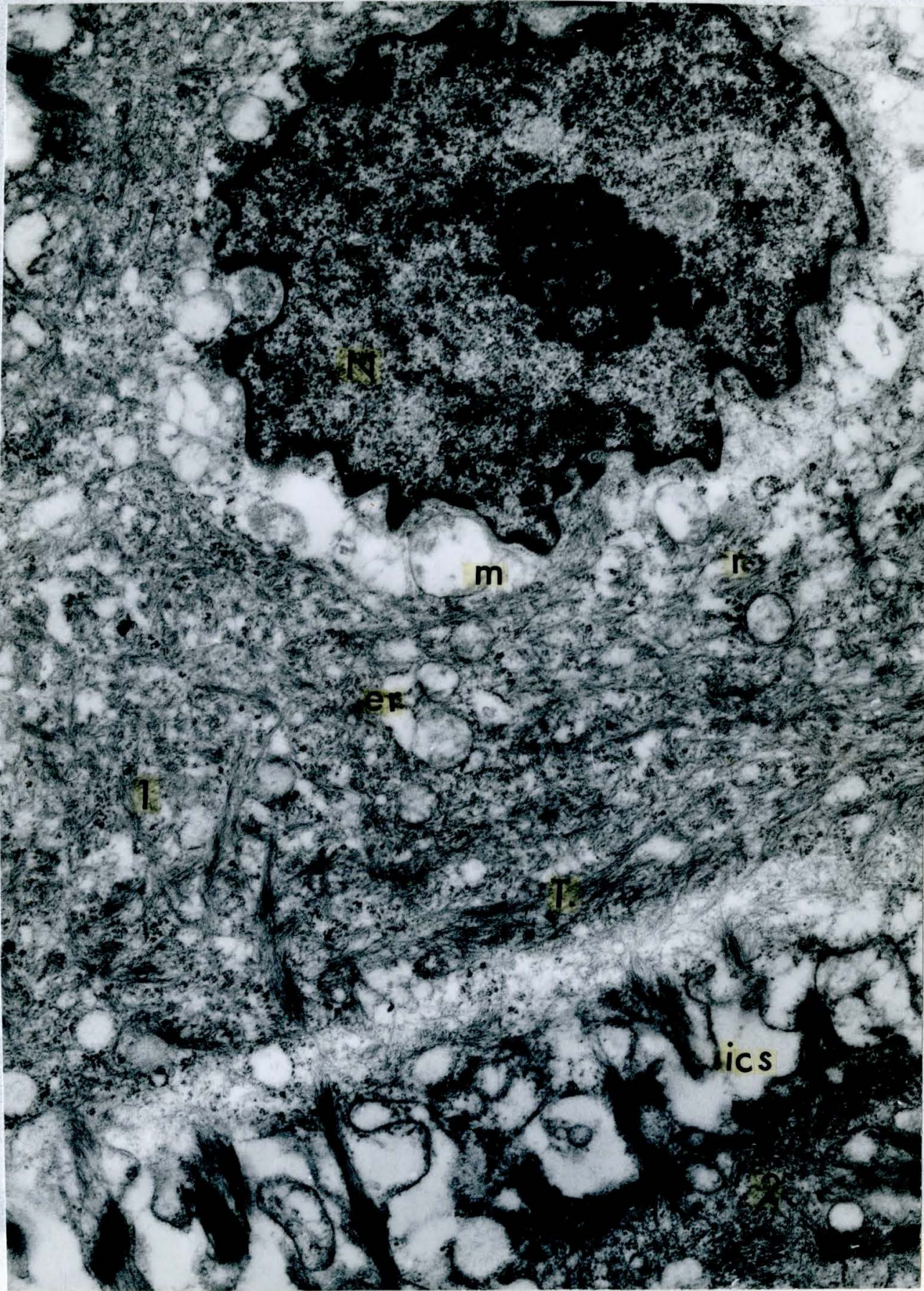

Fis. 37

2. day post-frozen bLopsy $(33,250 x)$

Stratus spinosum

Note: perinucless deras and widened intercel1ular spaces 


\section{4}

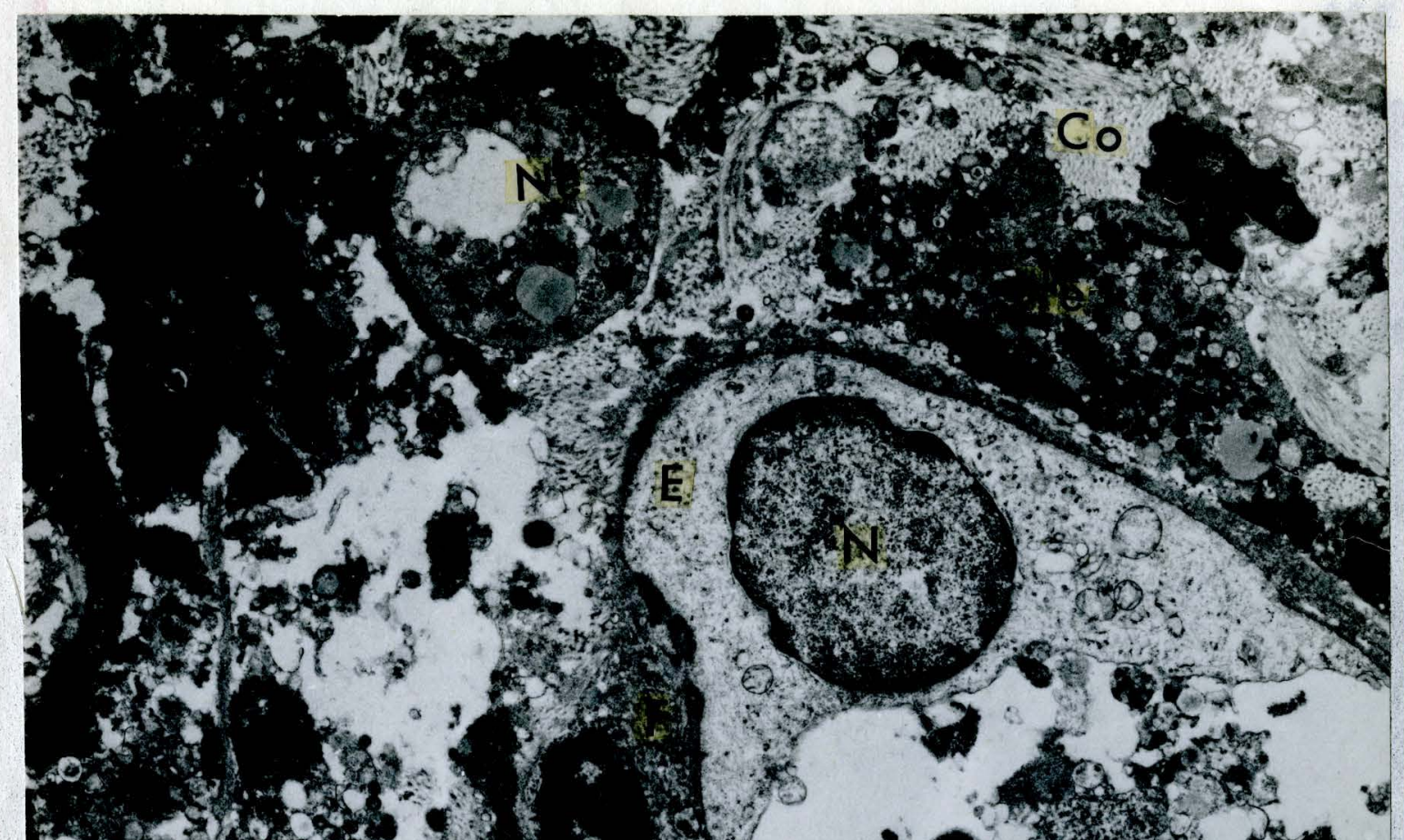

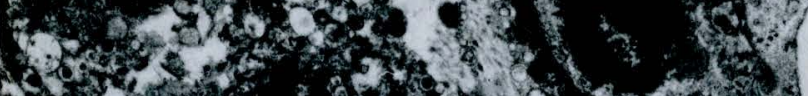

(3) C. 4.20

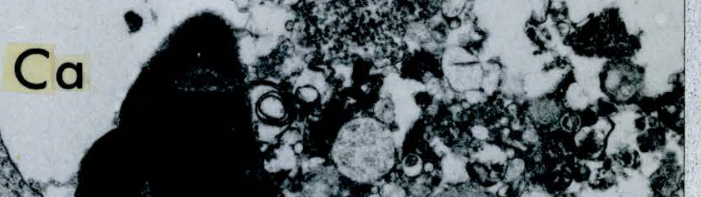
H.t.

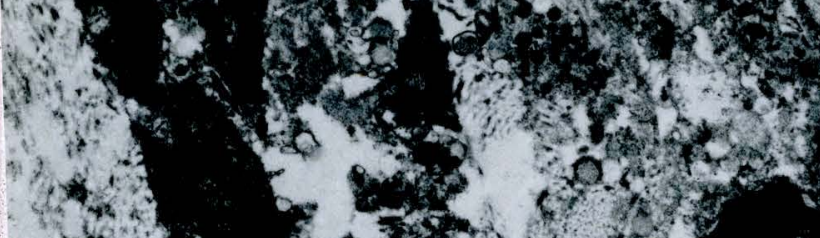

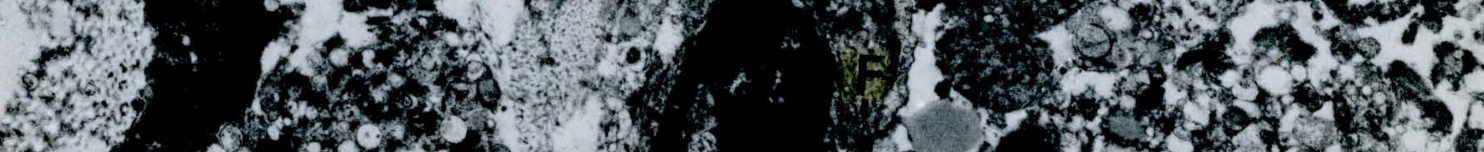

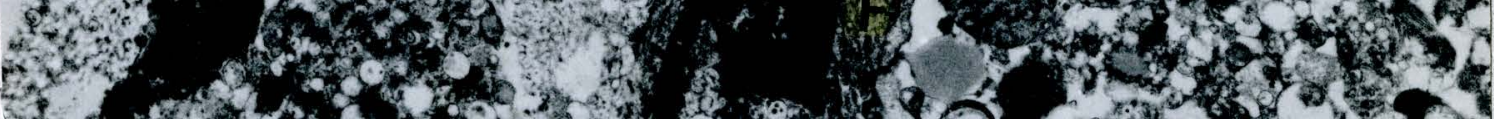

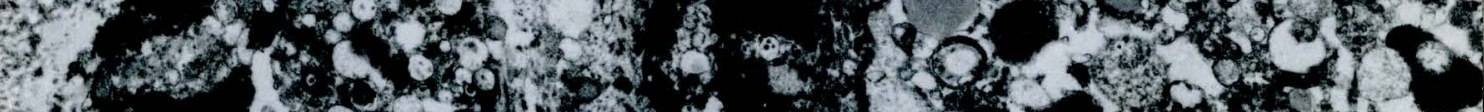

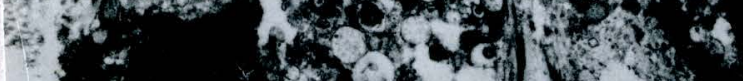

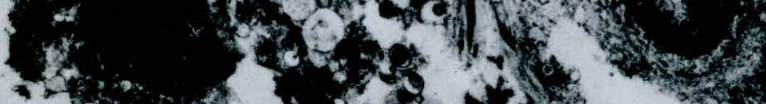

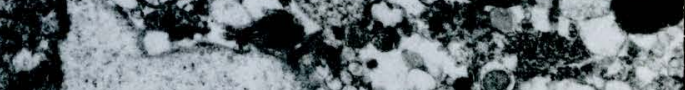

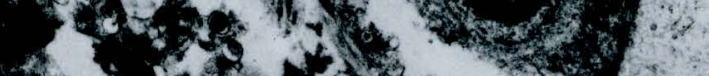

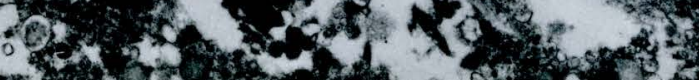

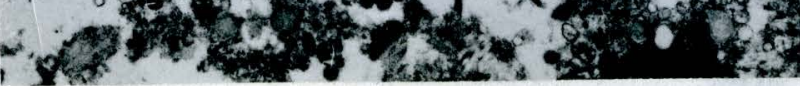

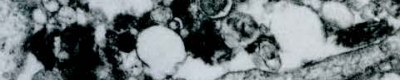

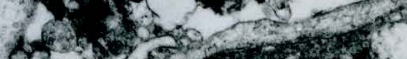

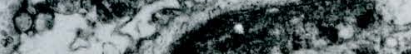
218. 38

2 day post-1rozen blopsy $(6,650 x)$ Connective tissue

Note: Bndothelial cell (E) and Capillary (Ca) 


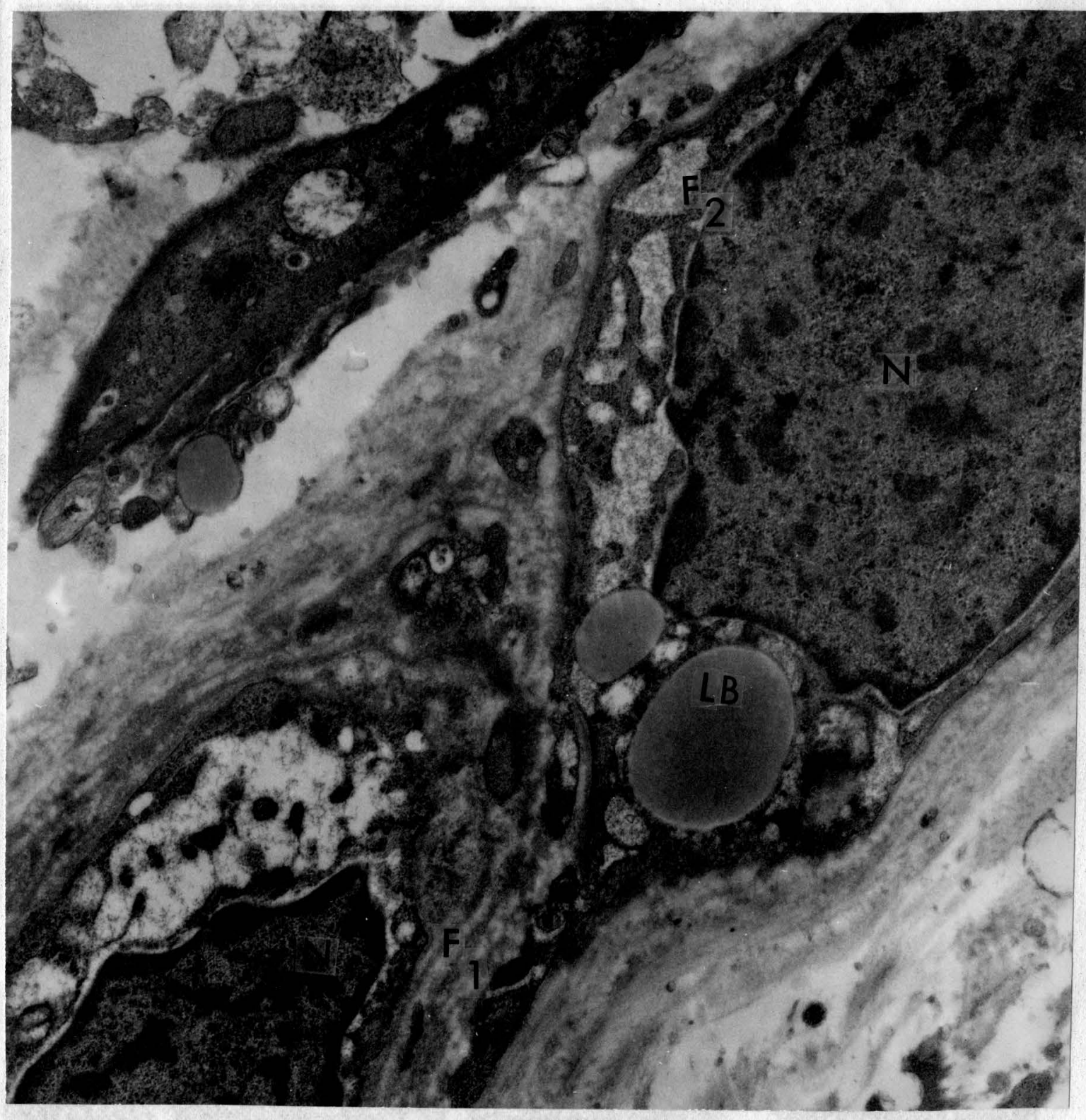

F18. 39

2 day post-frozen biopsy $(16,800 x)$

Connective tissue

Note: 2 fibroblasts(F) lacking

distinct organelles and exhiblting perinuclear edema (especially $p_{1}$ ) 


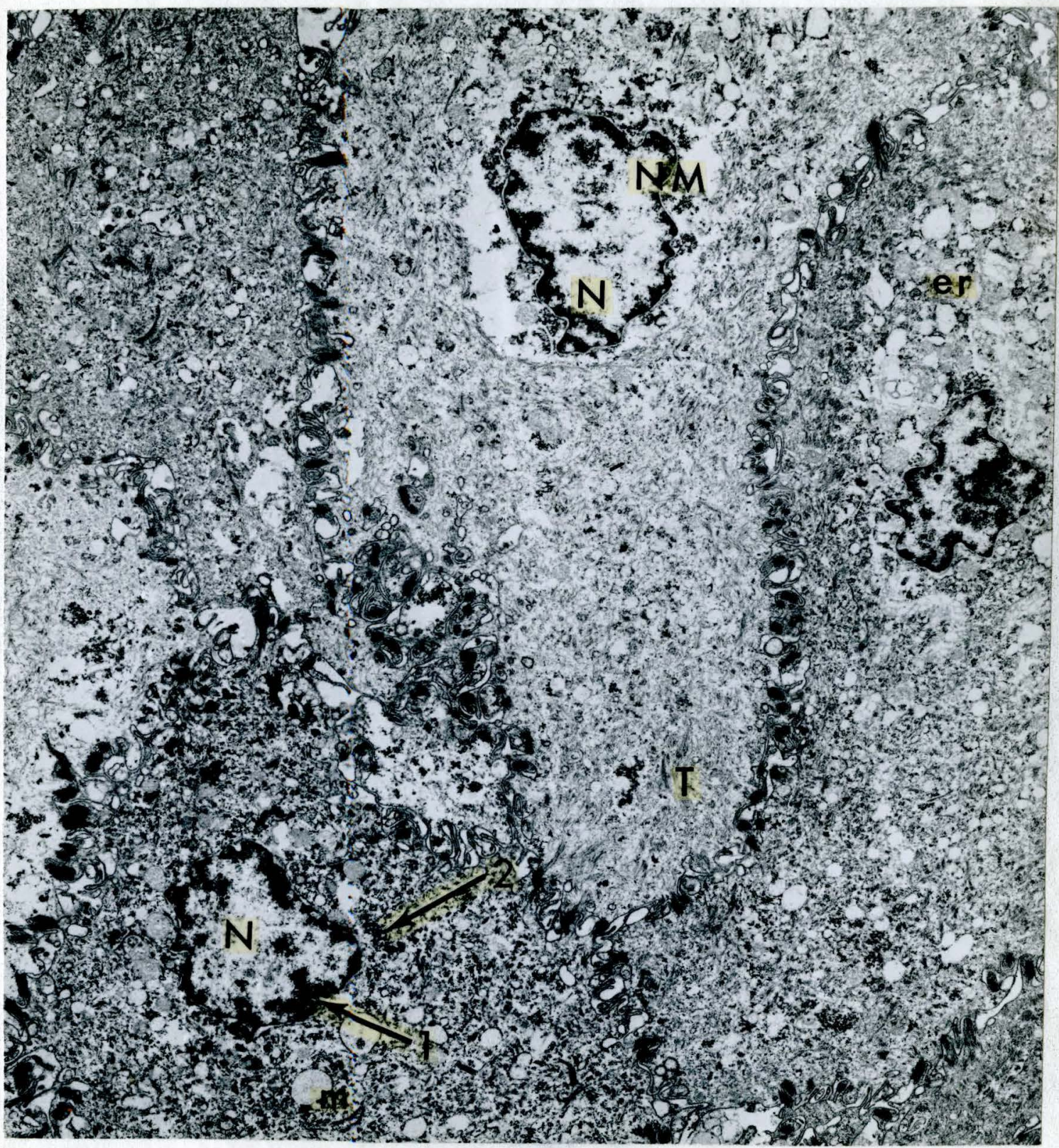

\section{FLE. 40}

\section{5 day post-frozen b1opsy $(6,650 x)$ \\ Stratum spinosum}

Notas alfserent staining characteristios of the co2.s and olumping of chromatin material. 


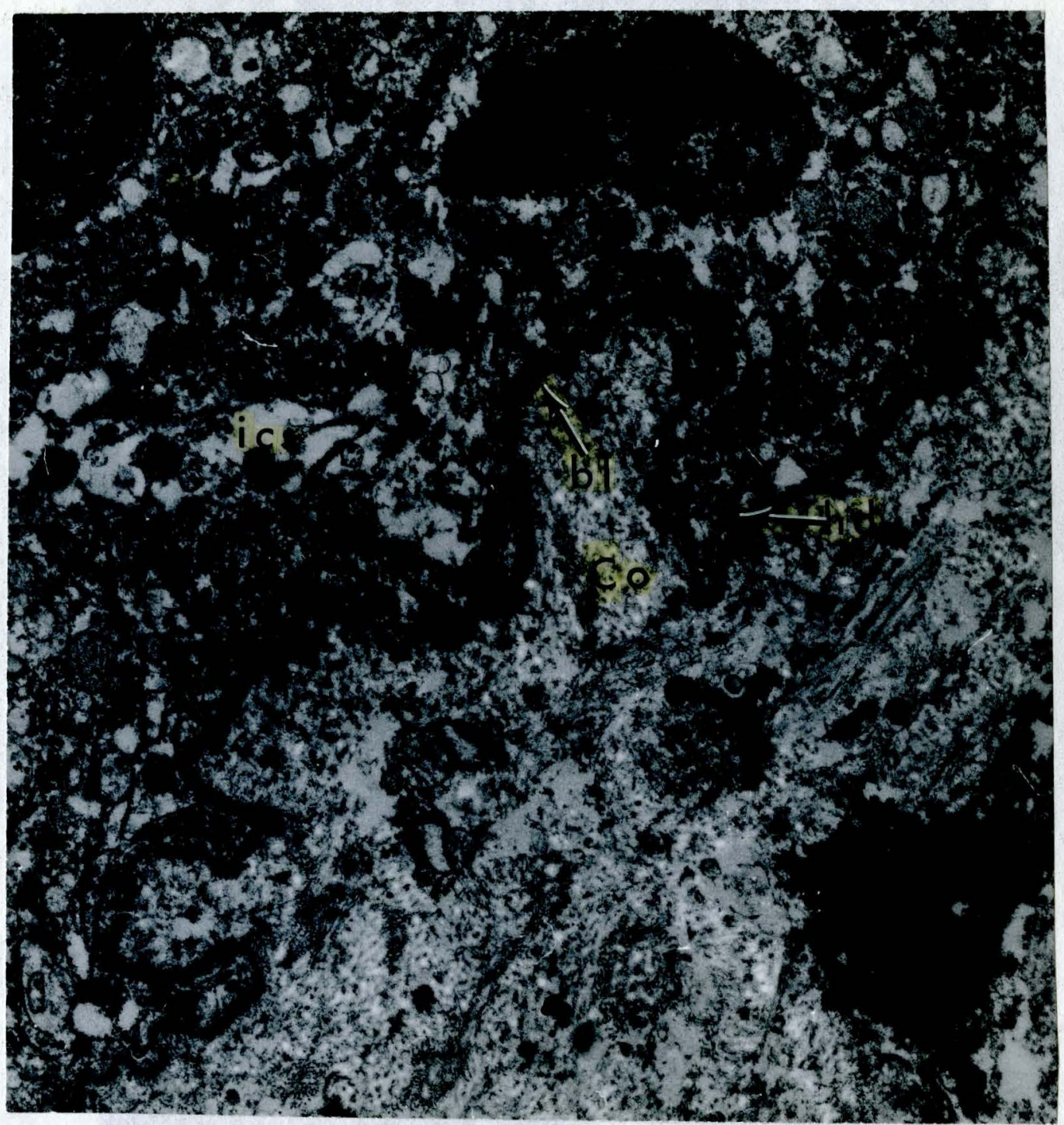

F1g. 41

5 dey post-irozen blopsy $(16,800 x)$

IpIthelio-connective tissue junction

Note: Intact basal lanins with poorly preserved hemldesmosones(hd) 


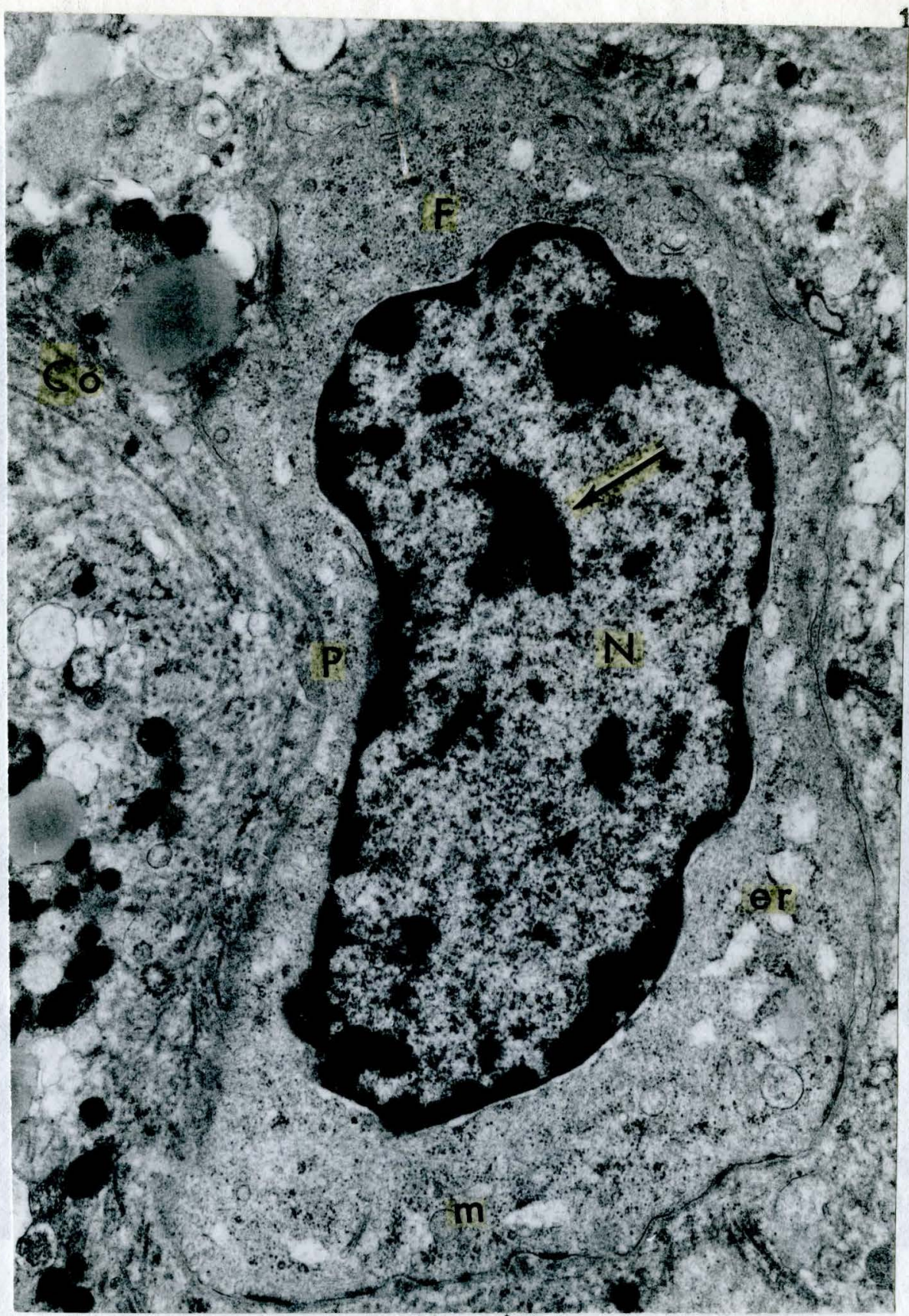

$$
\text { Fig. } 42
$$

5 day post-frozen biopsy $(16,800 x)$

Fibroblast

Note: indistinguishable nucleoli (arrow) and clumping of chromatin material 


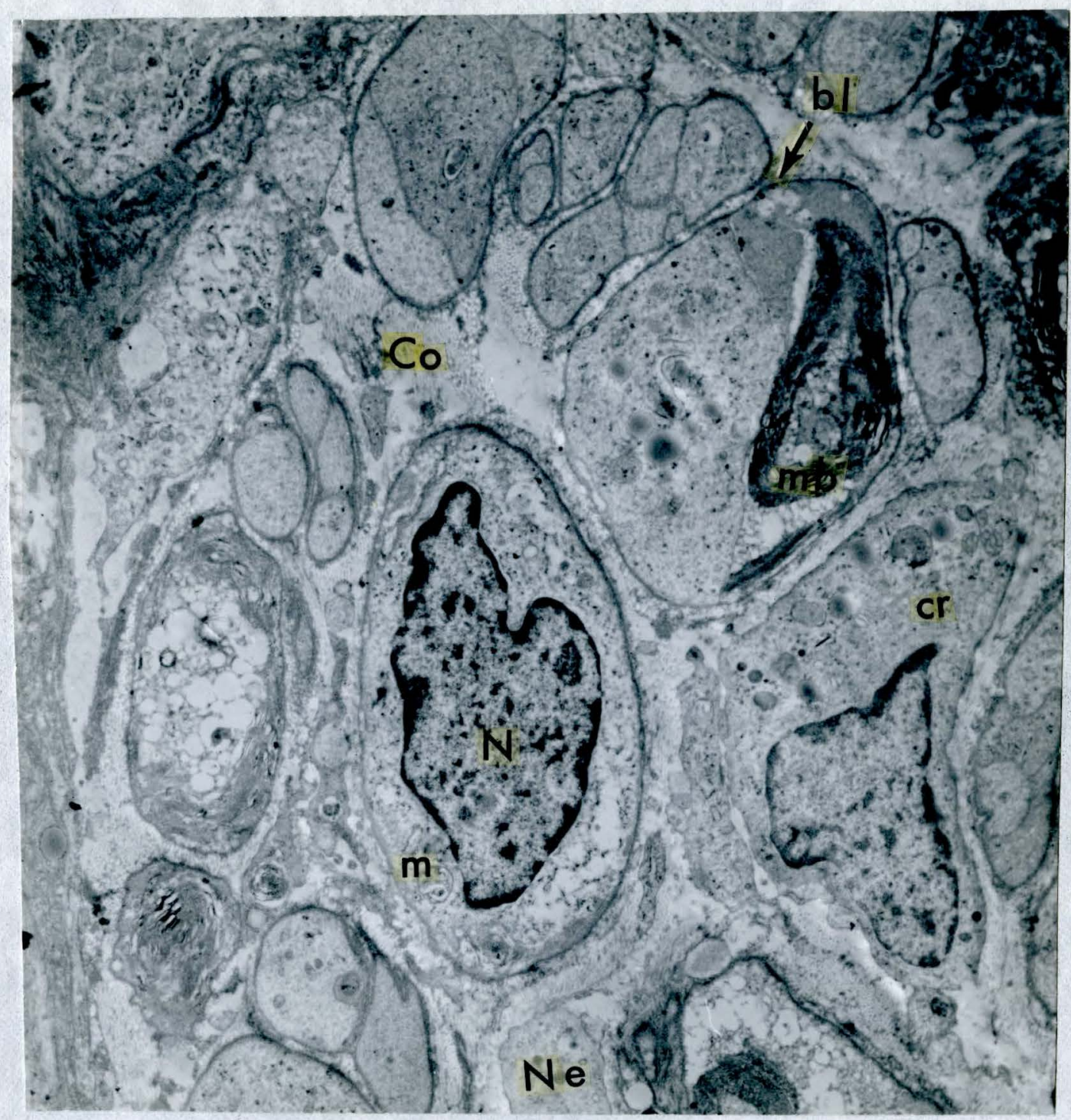

\section{F15. 43}

9 day post-rrozen blopey $(6,650 x)$

Basal oplthelium

Note, asction traverses the epithellal ridges. Dasal ce11a are surrounded by a distinet basal lamina(bI) 

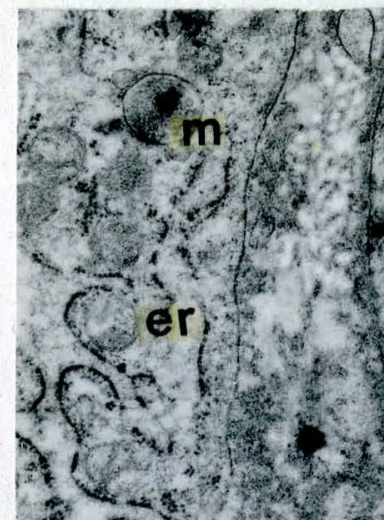

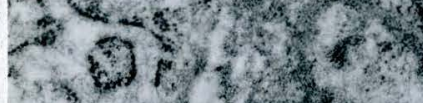

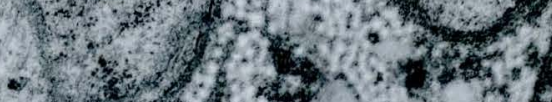

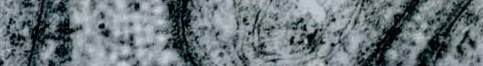

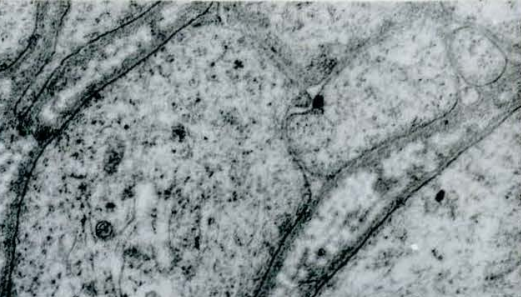

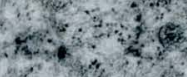

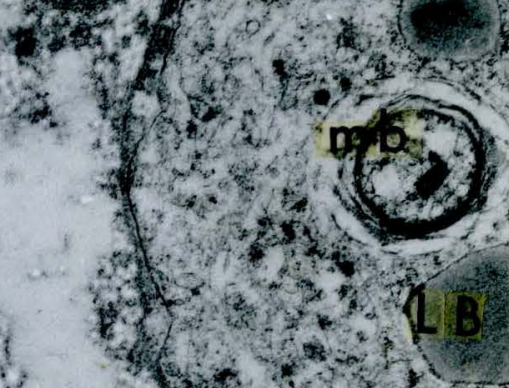

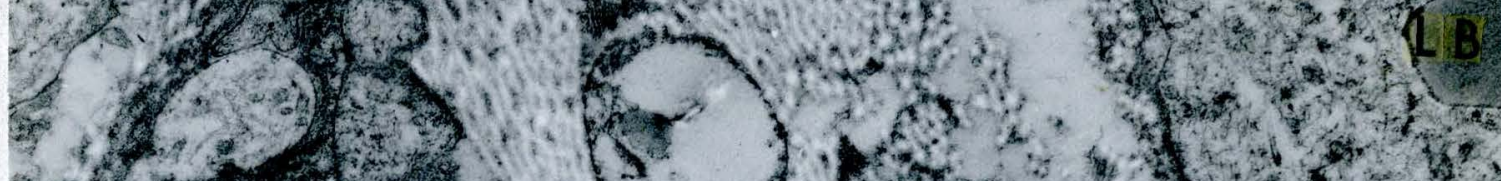

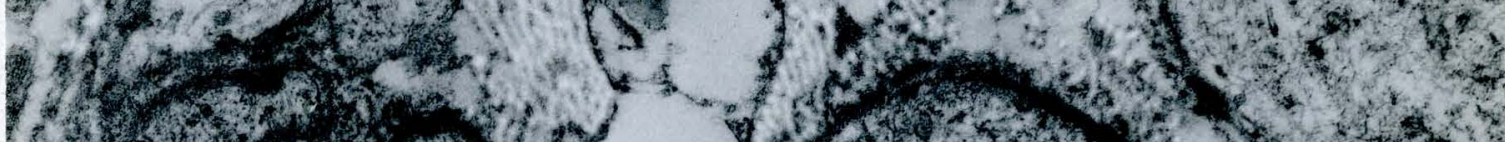

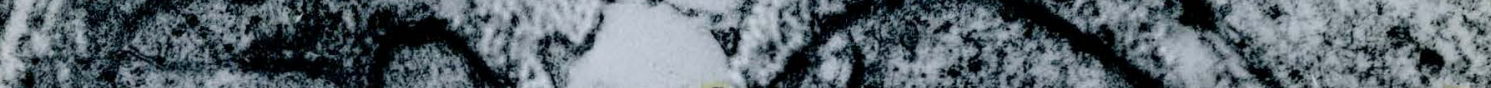

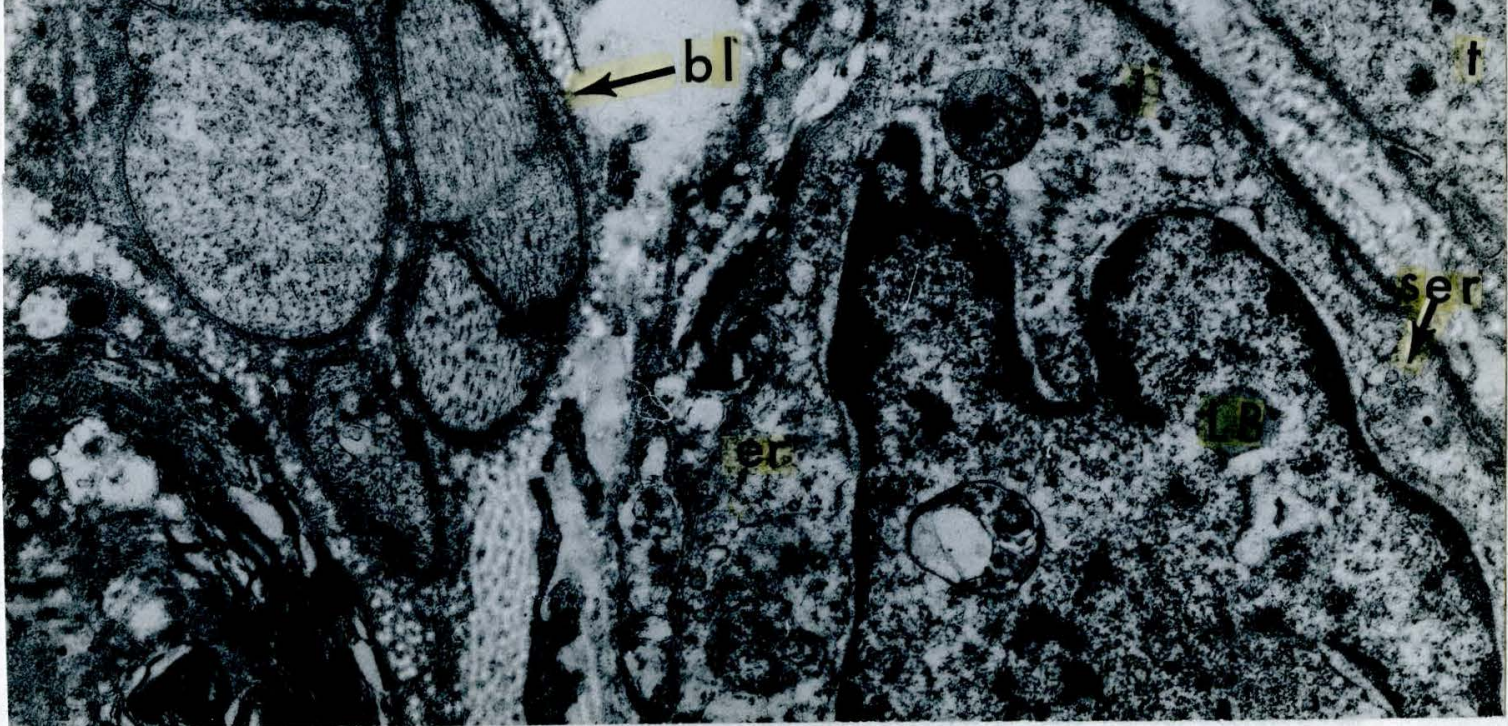
Fi: 44

9 day post-frozen blopay $(6,650 x)$

Bama1 ep the1Lum

Nota basal landne(bI) and rleh prom filea of cranuiar endoplastale retlowe lum(ex) in basal cella 


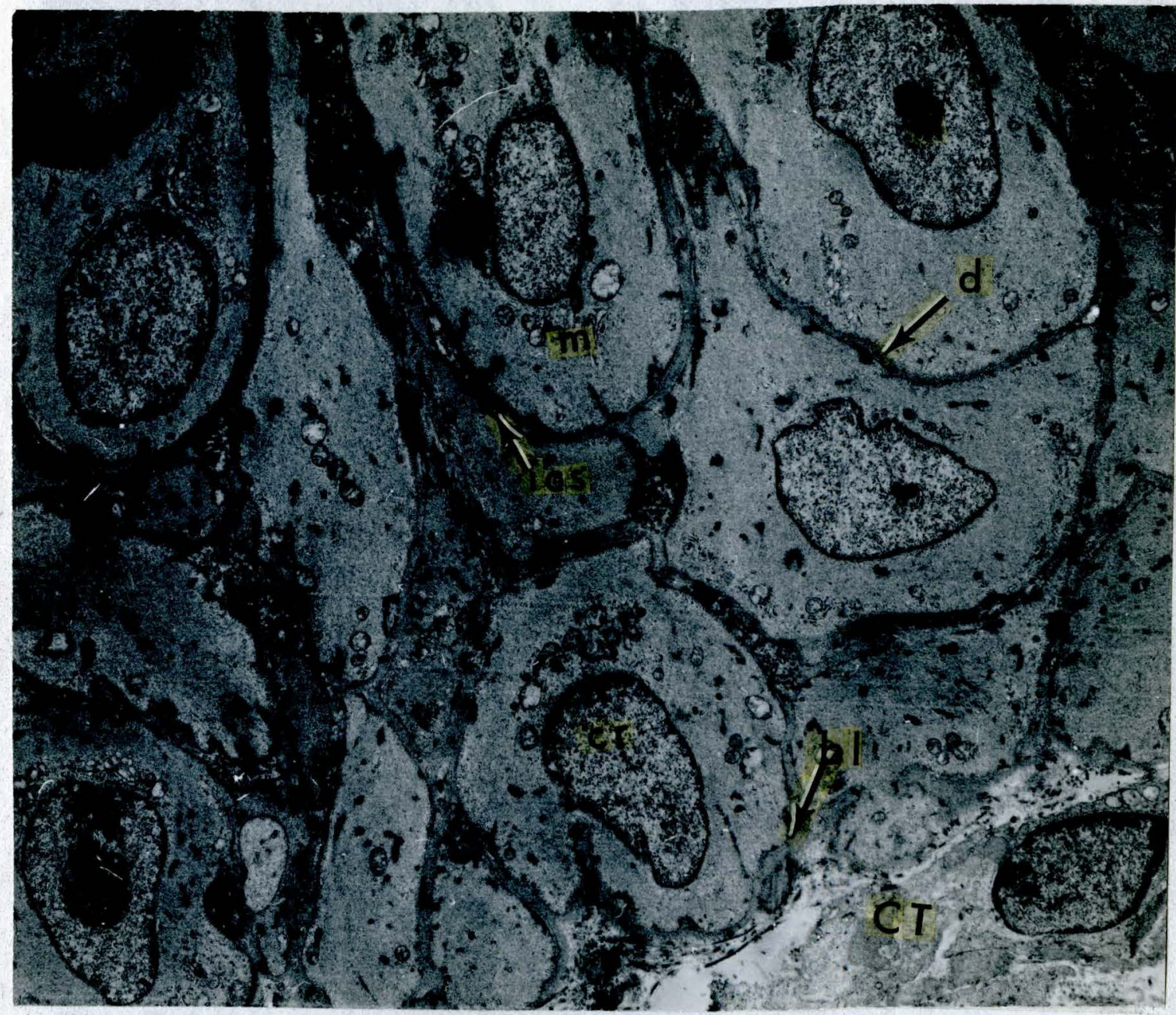

\section{45}

12 day post-mozen bionsy $(6.650)$

\section{Bosal epithezsurn}

Note: basal lamina(bi) is continuous with intercellular spaces (ics). Near homoreneous eytoplesm exlsts throughout the epithelial cel1s. 


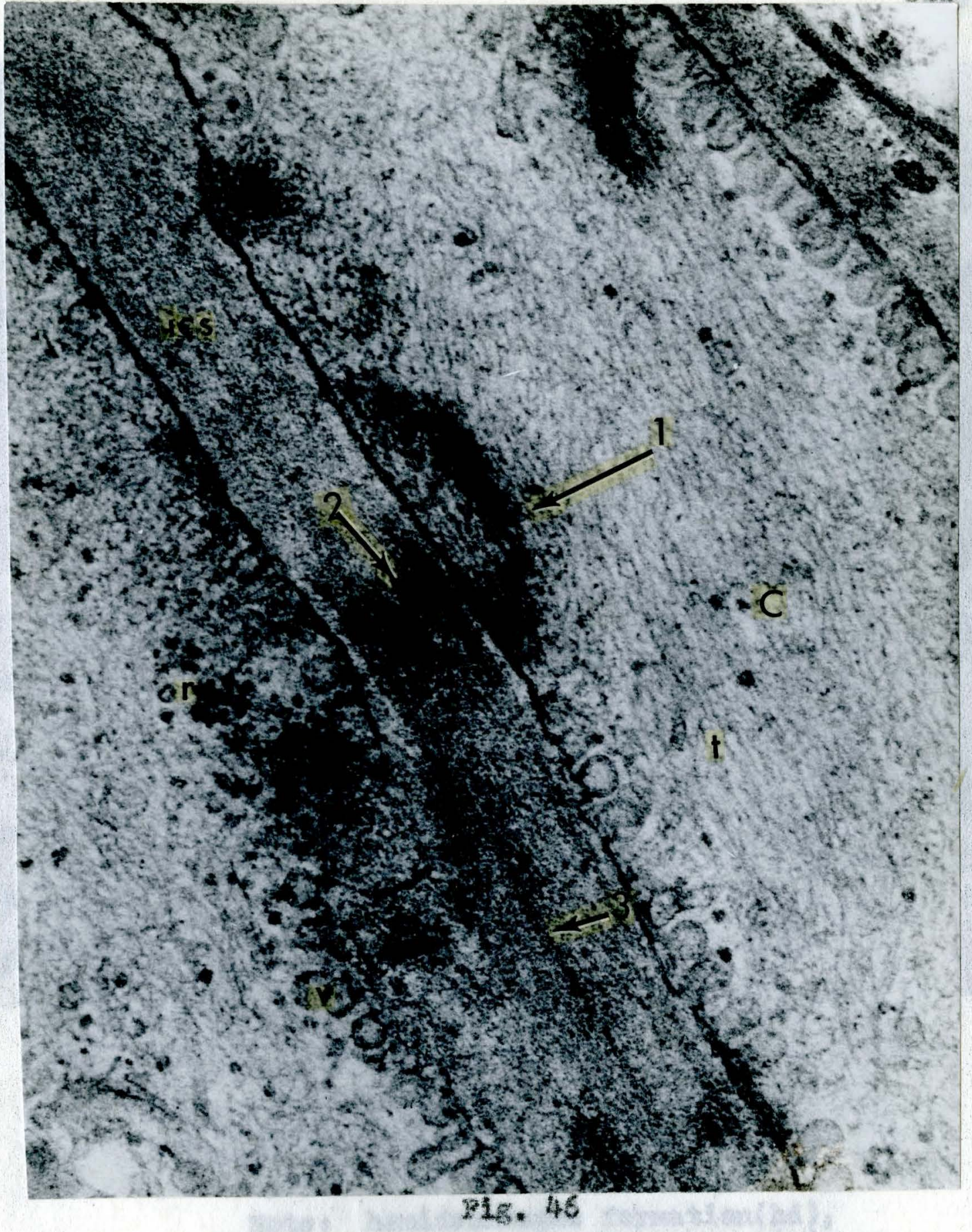

\section{2 day postrotromen bioysy $\left(98_{0}, 000 x\right)$}

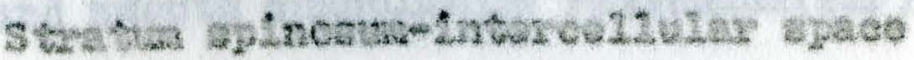

Note: Fresence of vesteles, appacent

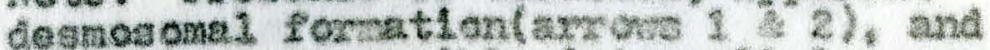

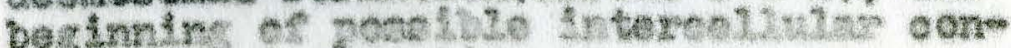
taet iay $-($ srreen 3$)$ 


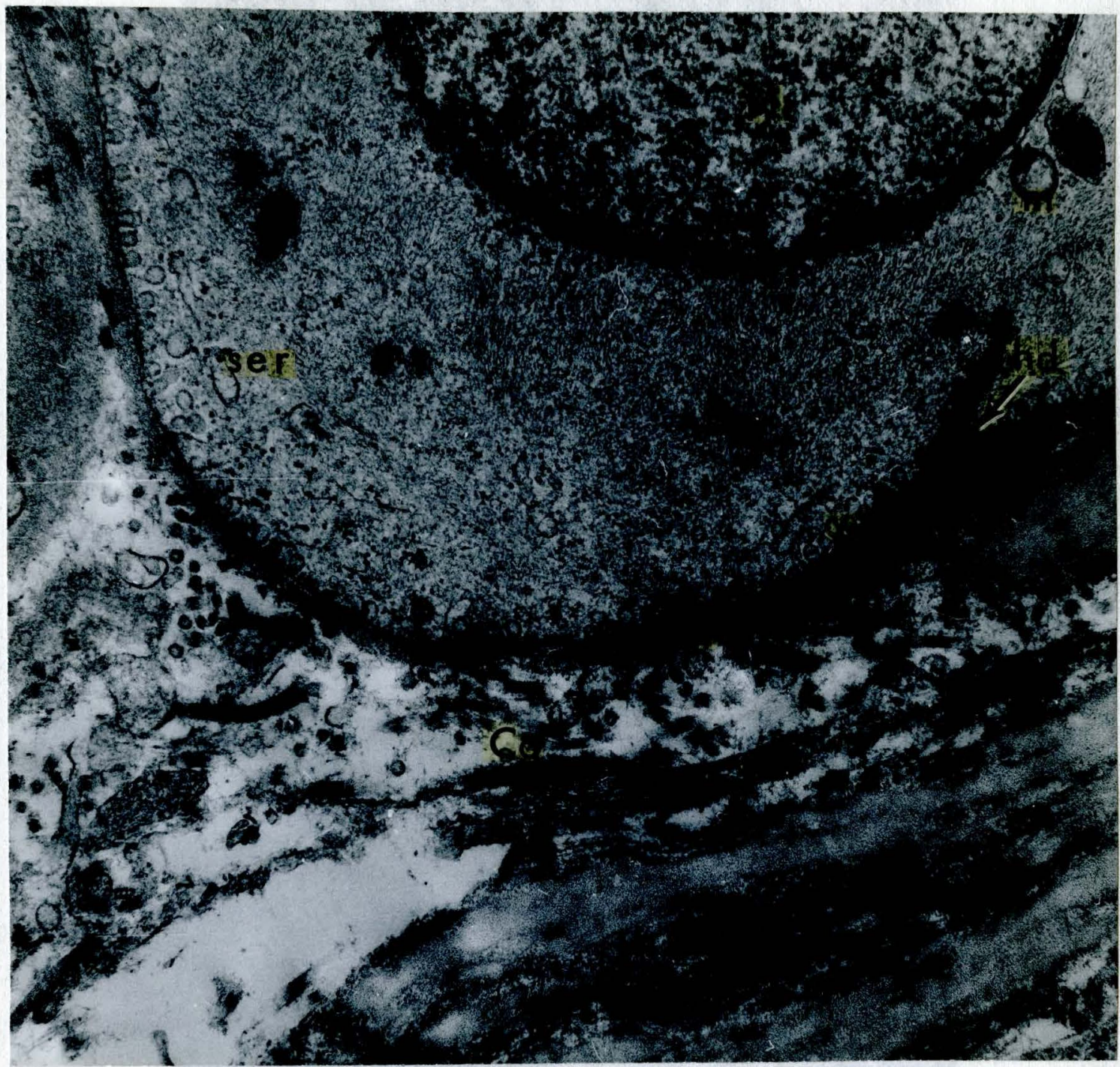

\section{47}

12 day post-frozen blogay $(33,250 x)$

Epithe110-connective tisaue junetion

Notes homidemasome fomation(hd). vosicles Iinins plasurs. norbrane $(v)$. and smooth endoplasmic reticutum(sox) 


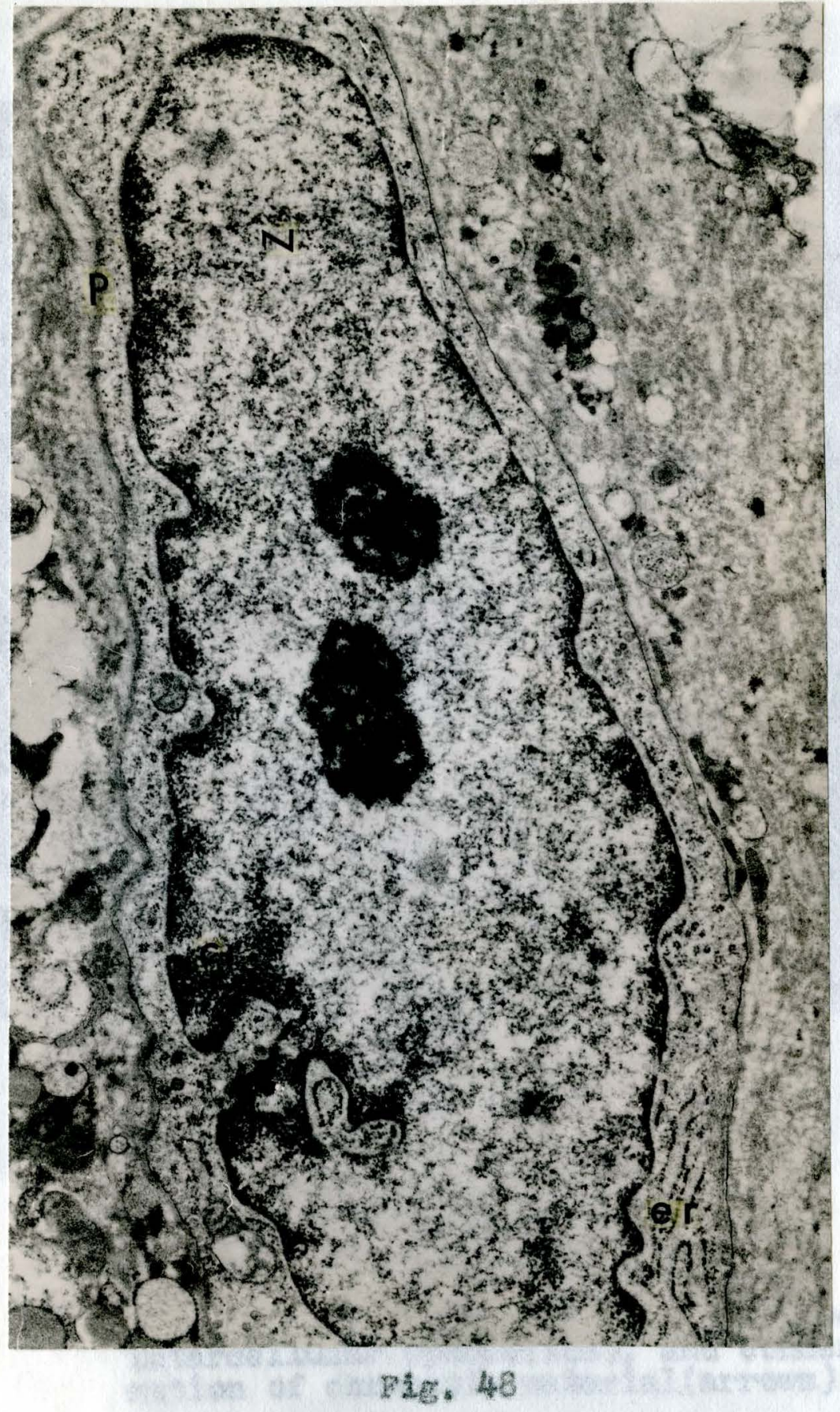

12 day post-frozen blopsy $(16,800 \times 0$ Tibroblast

Wotes meleolif(n) and clumplng of chromet $\operatorname{Ln}(\mathrm{er})$ 


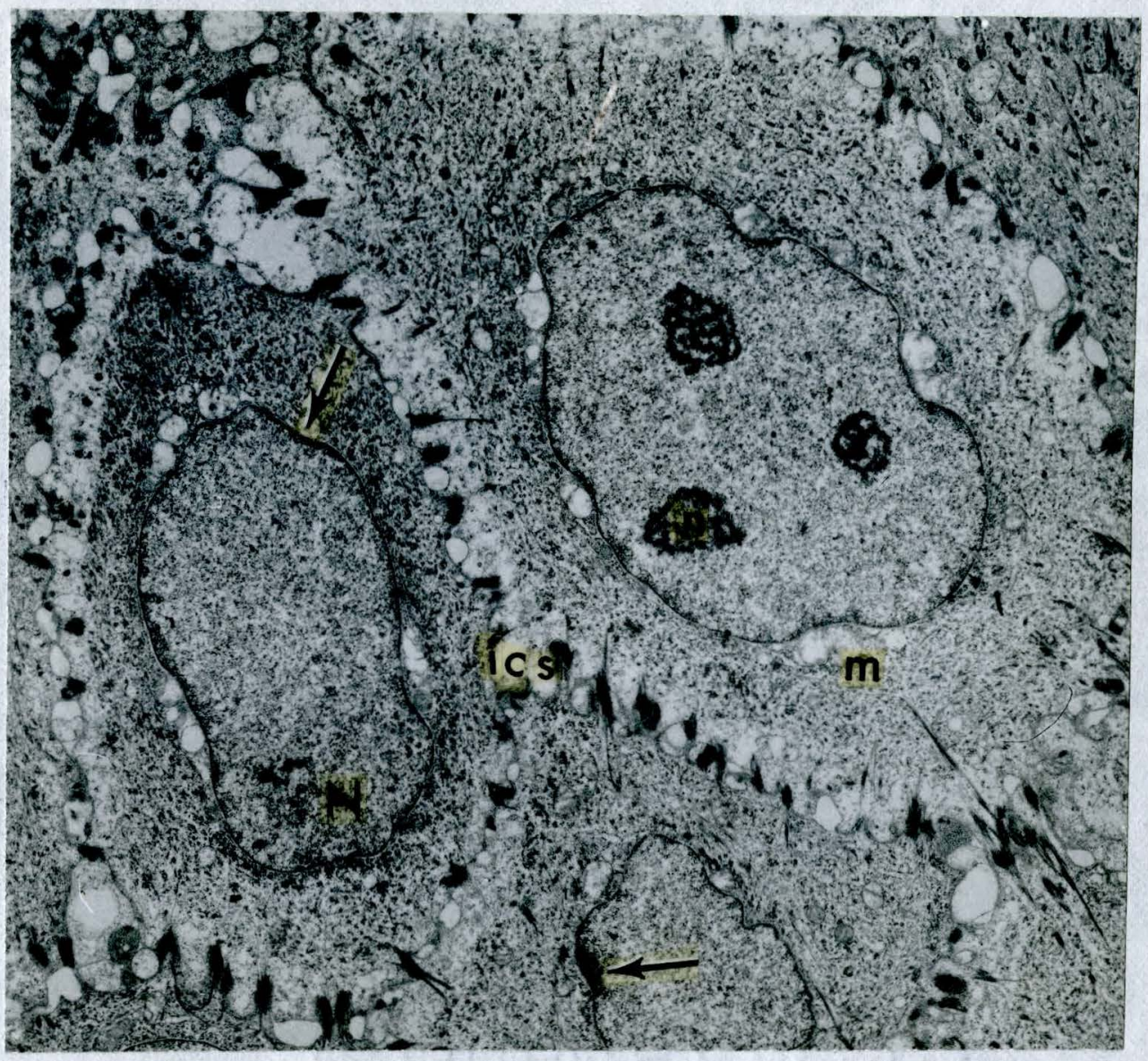

$$
\text { Pagis is }
$$

\section{5 day post-frozen blopsy $(16,800 x)$ Stratum spinosum}

Note: perinuelear organe1.2es, widened interceliular apaces(ics), and condensation of chromatin material(arrows) 


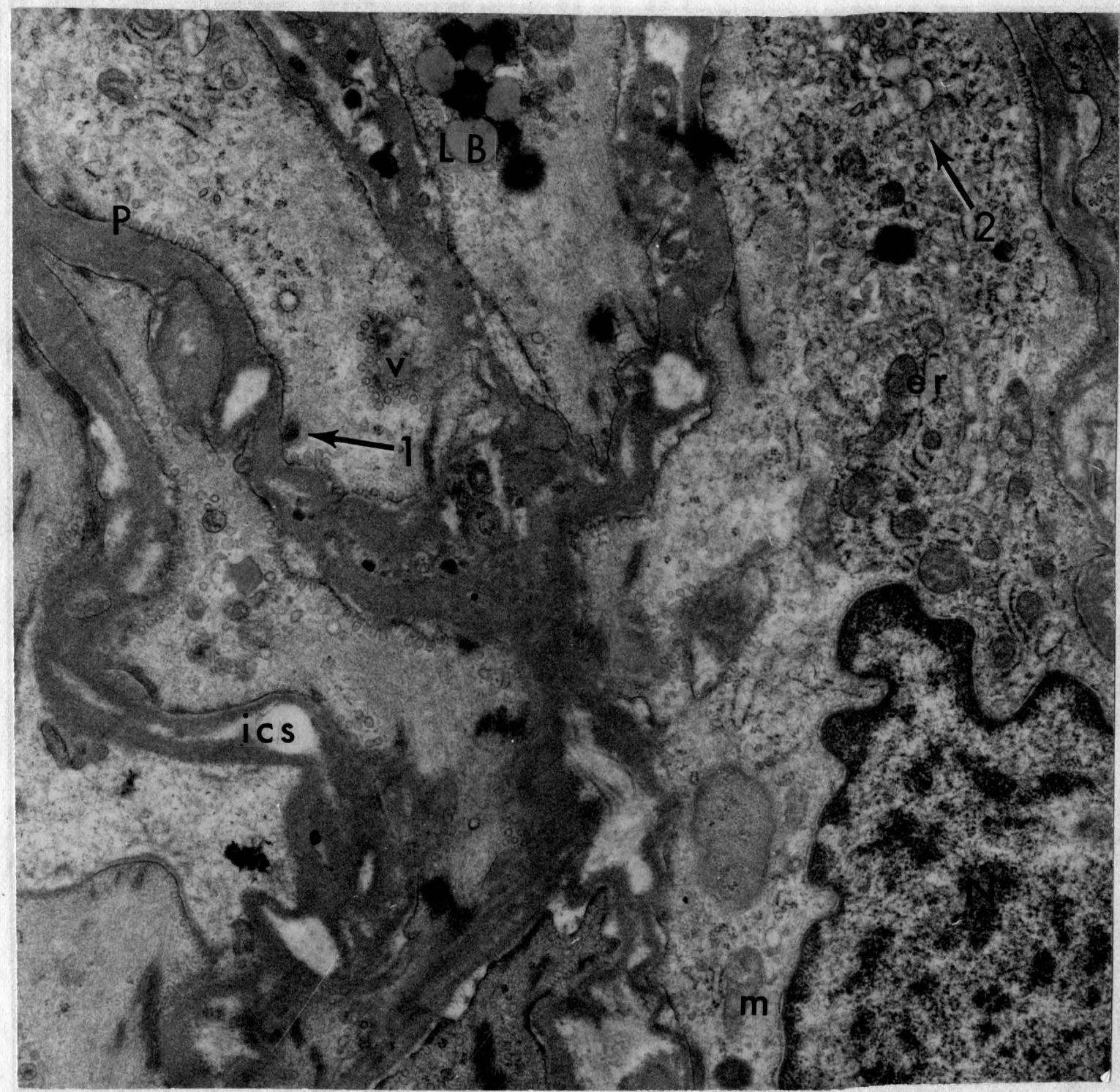

Rig, 50

\section{5 day post-frozen biopsy $(16,800 x)$}

Basal epithelium

Note: desmosomal formation(arrow 1) and association of vesicles $(v)$ with endoplasmic reticulum(arrow 2 ) 


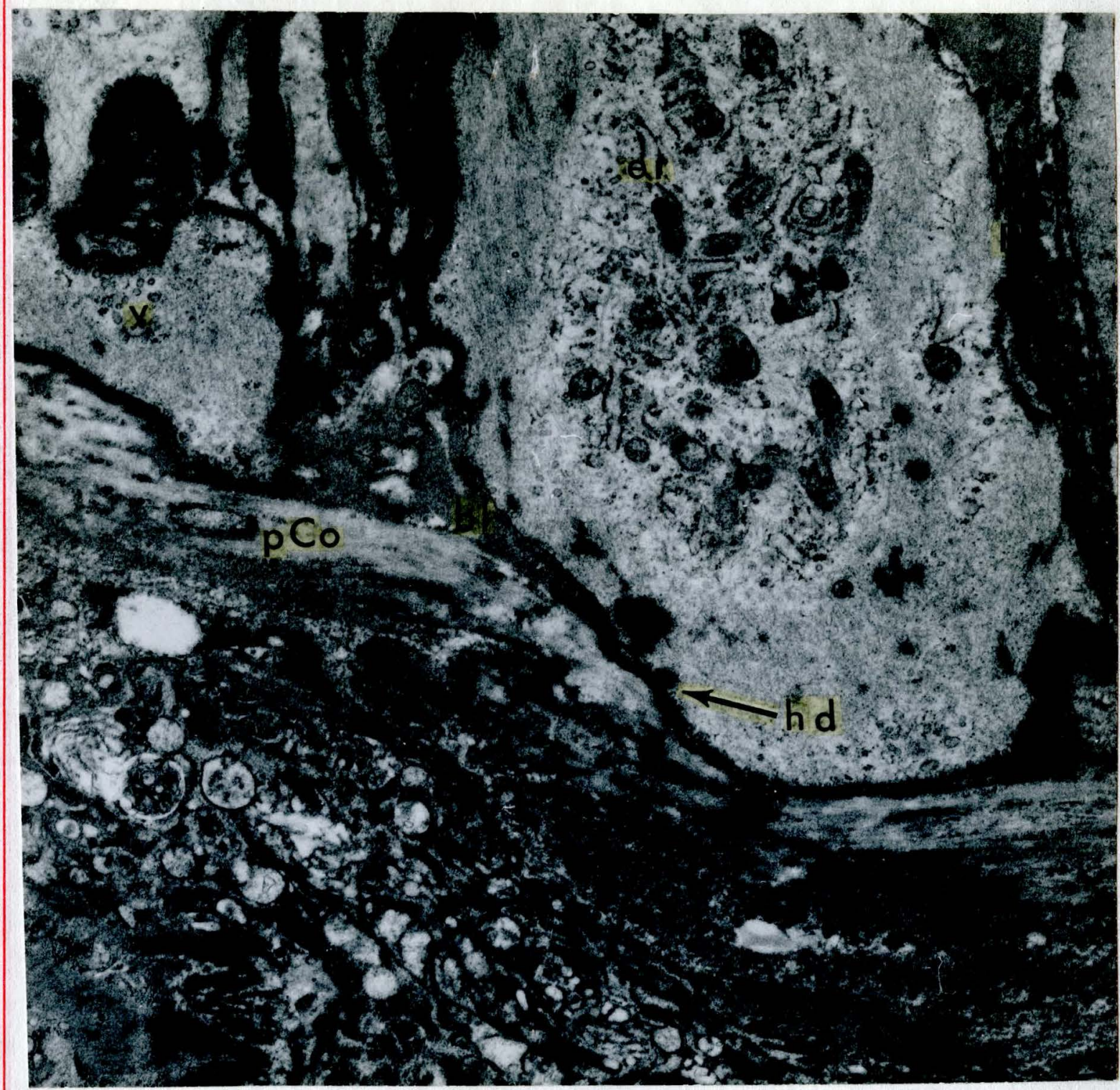

\section{F15. 51}

15 day post-Ixozen biopsy $(33,250 x)$ Ipithe1io-connective tissue junction Note: Hemldesmosome formatlon(hd) and pre-collagen(pco) within the connective tissue 


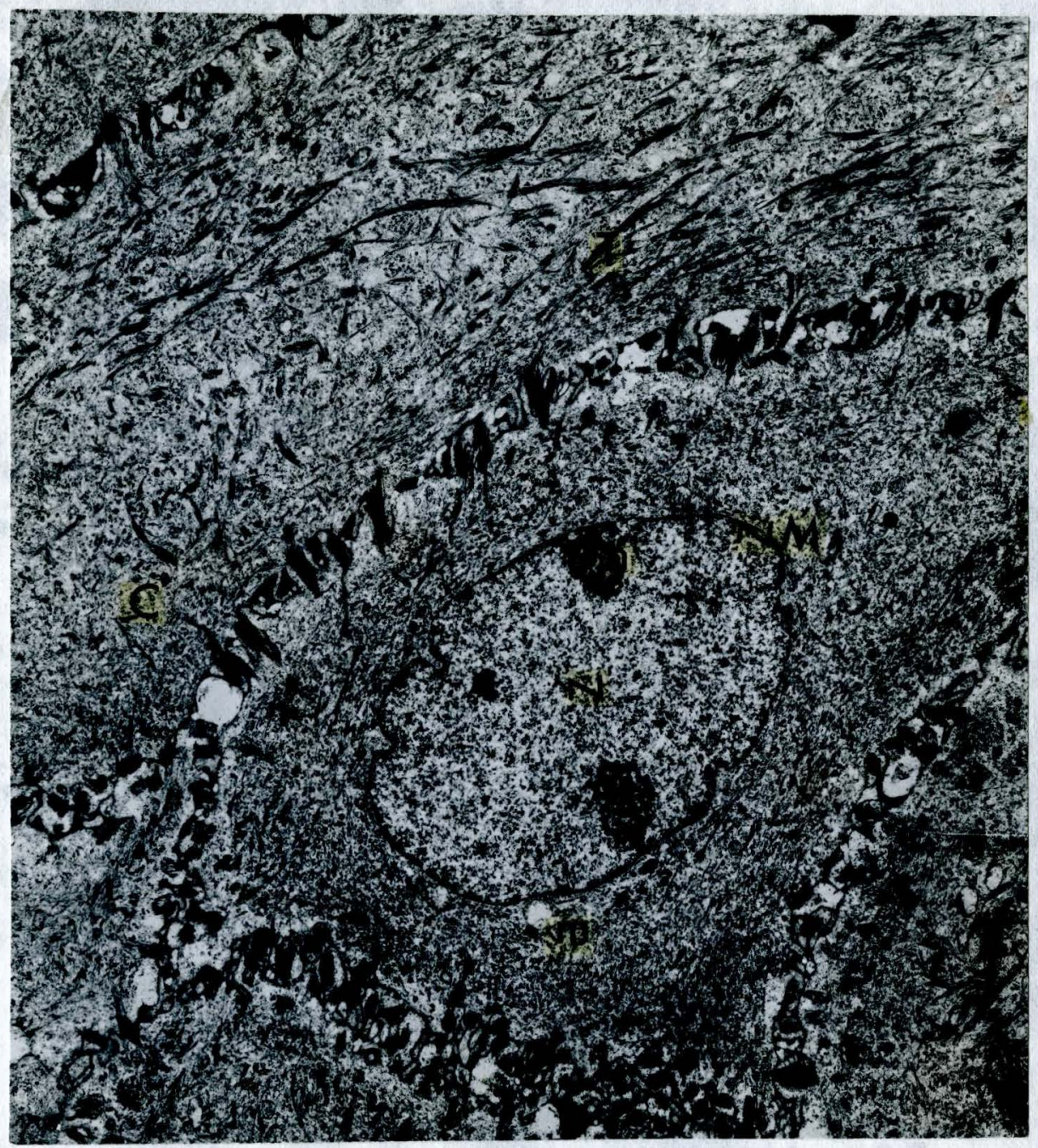

\section{Fig. 52}

19 day post-frozen biopsy $(6,650 x)$ Stratum spinosura

Note: widened Intercellular spaces(ies) 


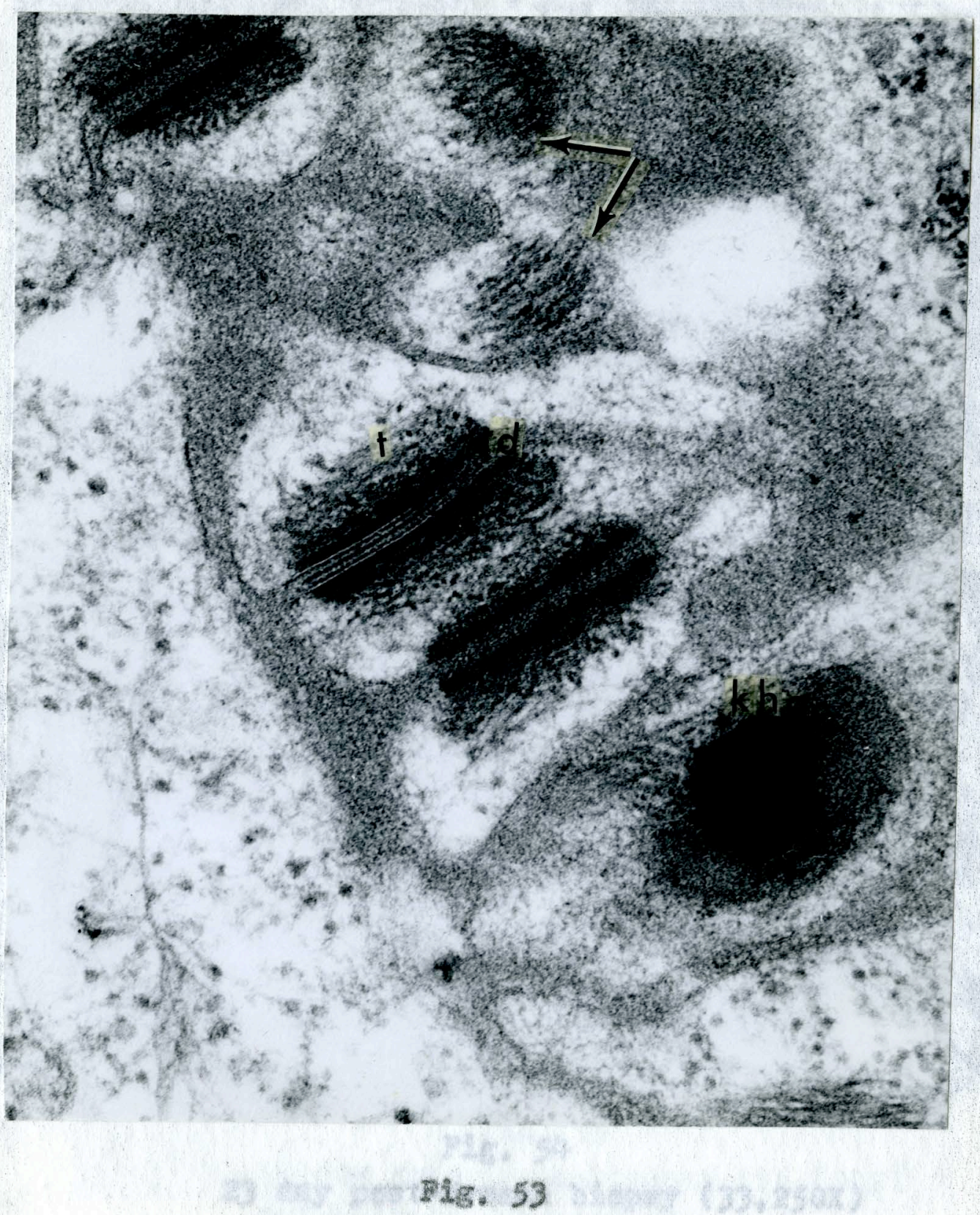

19 day postrfrozen blopsy $(98,000 x)$ Stratum granulosum-Lnteree1.2ular space Notes highly organized desmosones (d). areas of tonorliament condensation. and keratohyaline granule(khg) 


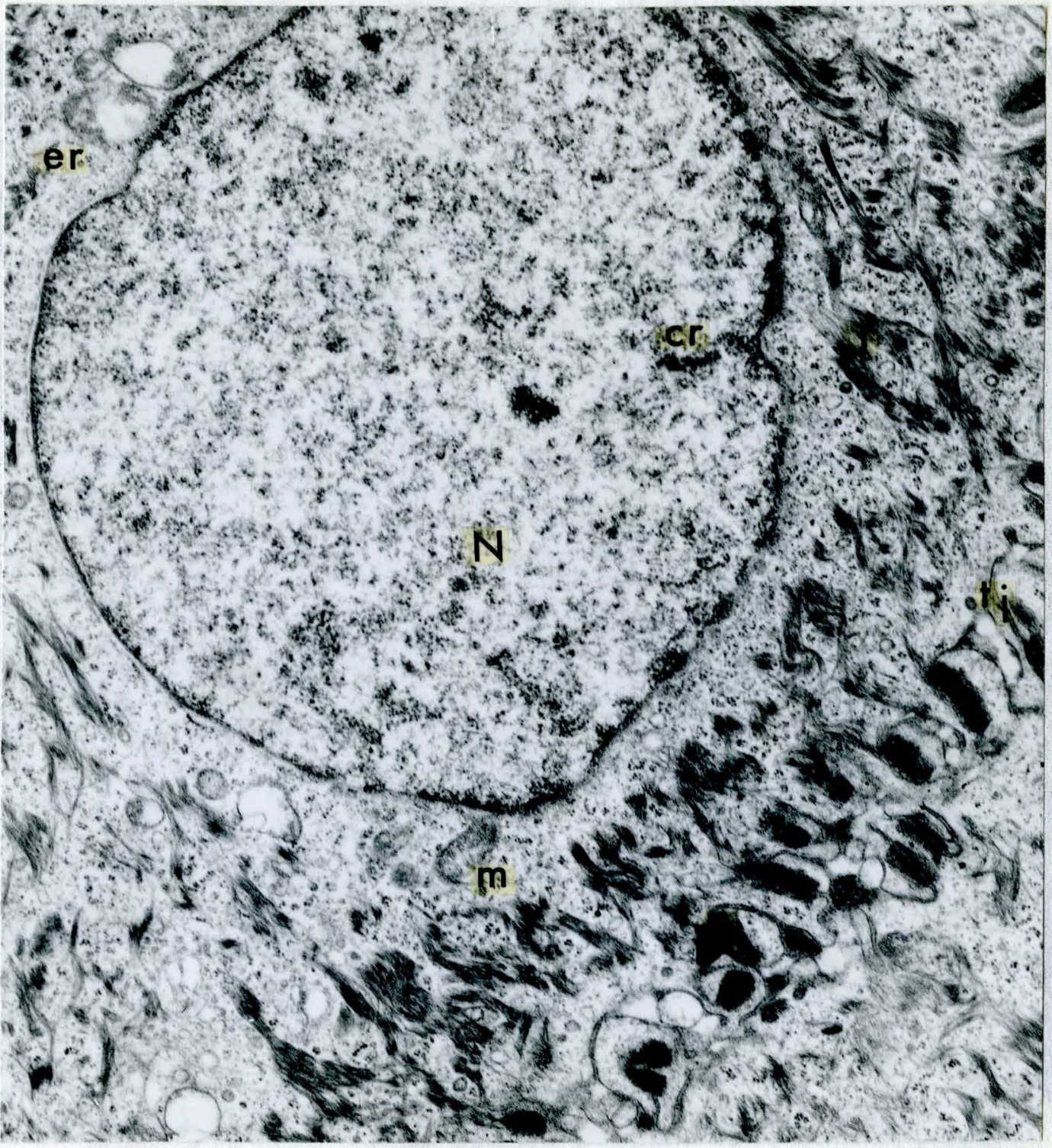

Fig. 54

23 day post-frozen biopsy $(33,250 x)$

Stratum spinosum

Note: good organization of cellular components 


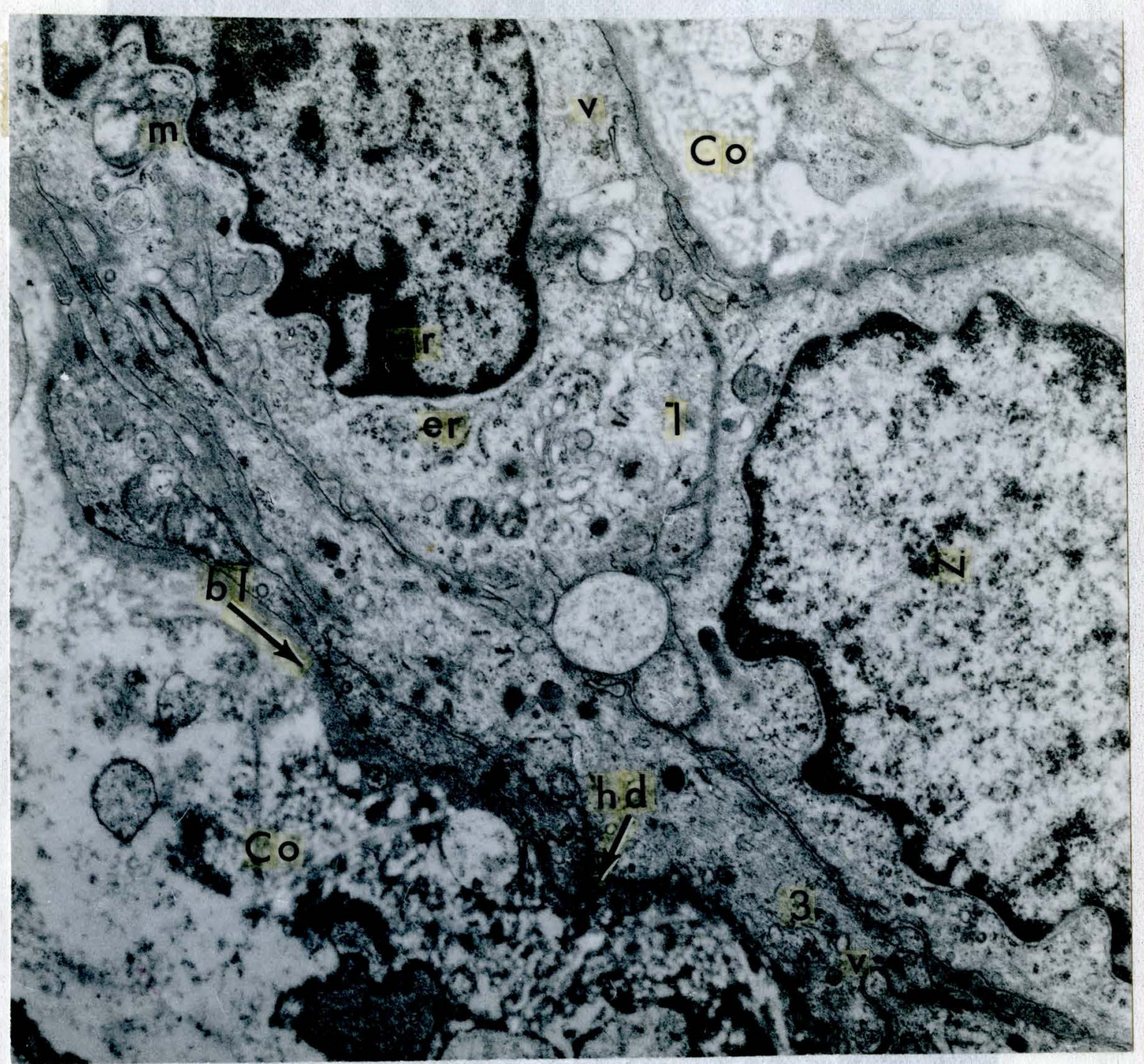

Fig. 55

23 day post-frozen biopsy $(16,800 x)$ Epitheliomconnective tissue junetion Note distinct basal lamina(b1), hemidesmosome formation(hd), and many profiles of endoplasmic reticulum(er) 


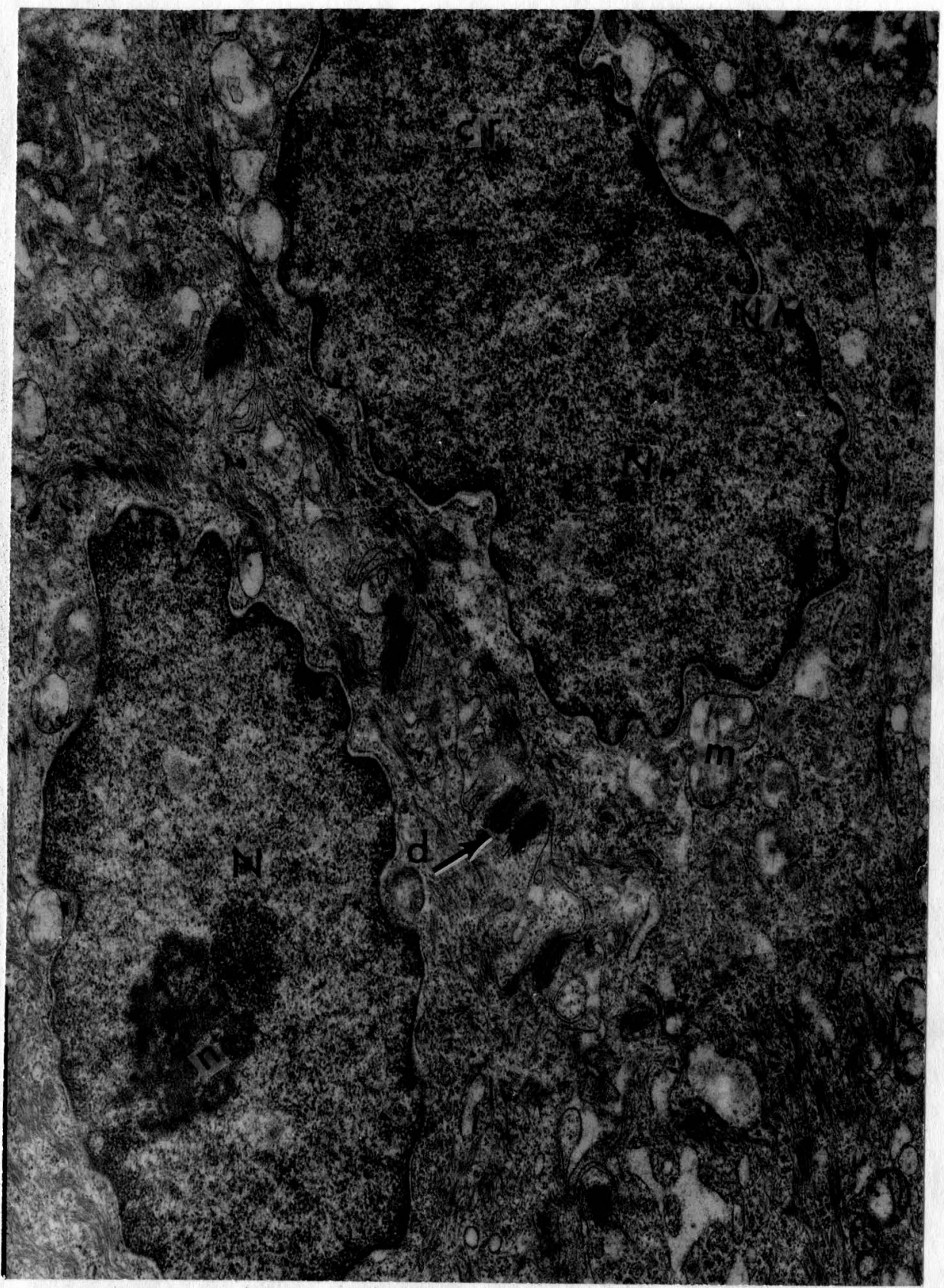

Fig. 56

30 day post-frozen biopsy $(16,800 x)$

Stratum spinosum

Notes fow intercellular attachments 


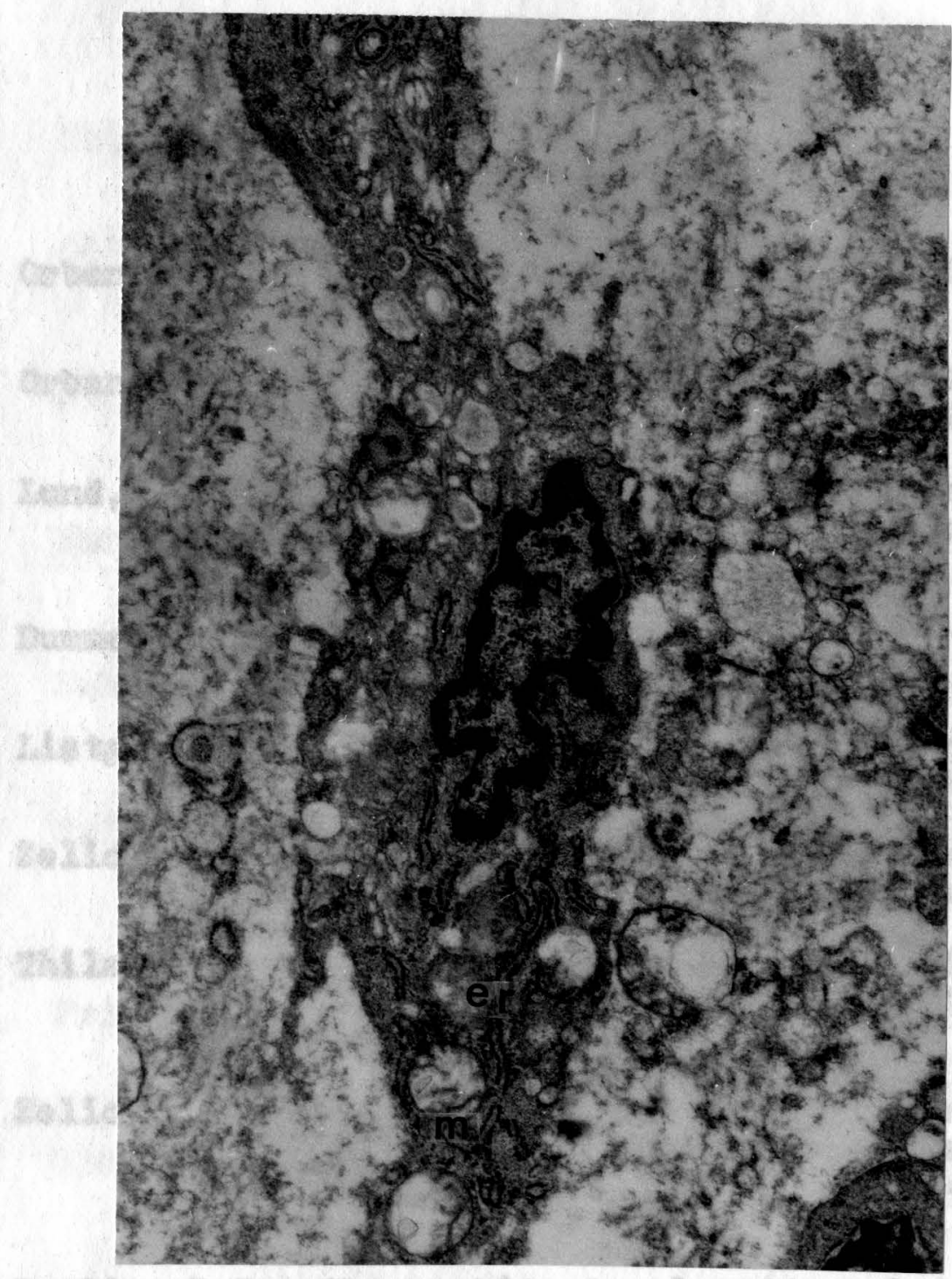

\section{Fig. 5 ?}

30 day post-frozen blopsy $(16,800 x)$

Pibroblast

Notes good organization of cellular components 


\section{Chandif IX}

\section{EITLIOARALHY}

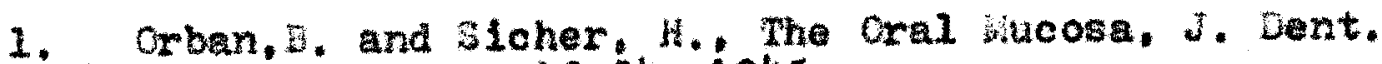
suc.. 10.94, 1945.

2. Orban. E. Oral Matology and Labryology, geventh ta.. C.V. Woaby. 1972, harry sicher (ed.).

3. Lund, 0., Hatologlsche geitrage zur Anatonio des 续unddachsand Faradentluns, Vrtljachr $R$. Zahnhe11k $40,1,1924$.

4. Dummett, 0.0. oral plgmentation. $J$. of Ferio. 31.356. 1960.

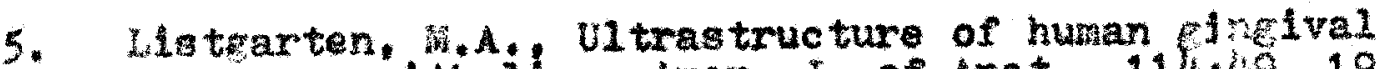
aptheilum. Amer. J, of Anat.. 114:49.1964.

6. Lelickson. A.3. U1 trastructure of normal and abnornal skin, Lea and Feglger, 1967. Filadelphia.

7. hilander, H. An lectron foroscople study of normal human palatal opt thellum, Acta, Odont. Scad.. $26.191,1968$.

8. Lelickson. A.S. and Hartmann, J.F. An electron microscopic study of normal human non-keratinlow ang oral tucosa. J. of Invest. Derm. $38: 99$. 1968.

9. Bnslie, R.D. The architectural pattern between opitho ilum and connective tisaue of the singlva. Eroc. Reg. Soe. Med.. 44.41. 1951

10. Charles. A. and Smiddy, 3. . The tonofibrils of the

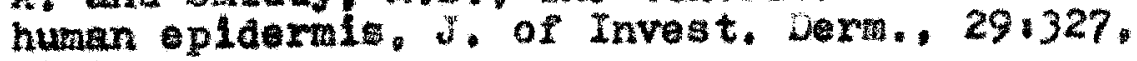
1957.

11. Squier. $c .3$. and Keyer, $J_{*}$. Current concepts of the hiatoloyy of orei mucosa, pub. chas. 0. Thomas, Springtleld, Illinols, 1971. 
12. Thilandex, J. and sloom, $G_{. .}$Cell contacts in oral ept thella, $y$, of Yerfo. Res.. 3196, 1968.

13. Mland, $F$, The fine structure of the Intermelatlonghtp of colls in the human epldermis, J. Blophys.. Blochem., cyto1." 4529, 1958.

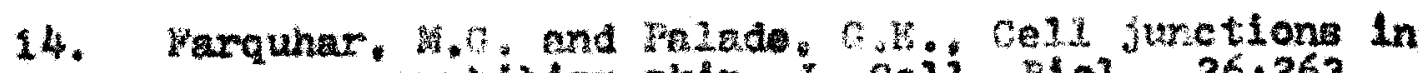
amphibian skin. J. Coil. Blol., 26.263. 1965.

15. Farquhar, $t^{4}=$ and Palade, 4 , sunctional conplexes in various epl thella, J. Cell. Blol., 171375.1963.

16. Schroeder, 1i, E, and Thellade, J., Llectron mieroseopy of normal humen olnetval ept the litur $J_{\text {. }}$ of Per3.0, Res.. 1.95, 1966 .

17. Pithiof, I, and Wereali, J.. 1ectron microcecpic observations of hyperderatinizet ton in oral mucosa. Acta. Otolarymolosica supplement, $3.88,423,1.963$.

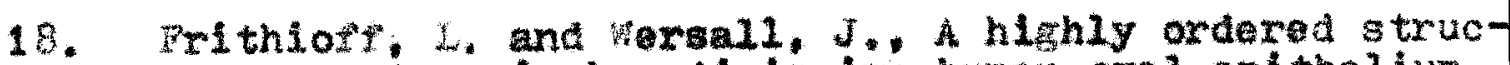
ture in keratinlze in human oral pishelium, 5. UItrastrue. Res.. $121371,1965$.

19. Stern, J. is. Electron microscople obeervations of oral epl thellum, I. lasal colls and the basenent nembrane., J. Aner. Soc. Perlo." $3.22 h, 1965$.

20. Meyer, $y$, and cerson, $3 .$. comperison of human palatal and buccal mueosa, $I$. inner. soc. ier10., 2,284, 1964 .

21. 3leher, 1. and kularul, E. I., Oral Anatoray, Fifth Ed., C.V.

22. schour, 1., hoye's Oral histolosy and abryology. ighth Ea., Lea and Febluer, 1960.

23. Materhouge, J.P., Calls of the lamina propria in current concepts of the oral mucosa. od. Squiler, C.A. and Hayar, J. Bpringfleld, 1971. 
24. Lockhart, R, D., Heriliton, $Q, P$, and Fyte, $F, W$, Anatomy of the fiuman Body, J, B. Lippincott Co., Philadelphia, 1959.

25. Woskowiez, L., Veber die Verphanzung thierseher Epldermislaeppehen in die Wundhoele., Arch. viln. Chir, $108,216,1916$.

26. Bssor, J. F., Studies in plastic surgery of the face, Ann. Sure., 65.297, 1917.

27. Plckeri21, H., Intraoral skin grafting: the establishment of the buccal suleus, Enit. J. Bent. Sc1.. 321135. 1919.

28. Q1114et, H, D., Plastic Surcery of the Face, Oxford Untv. Press, Lonãon, 1920, pp. 193-208.

29. Waldron, 0. In cillies(od.), Flastlc surgery of the Face, oxford Univ. Press, Londen, 1920, pp. 193-208.

30. Kilner, T, P. and Jackson, T, skin grafting in the buceal cavity, Brit. J, Sur: $91148, J 43 y$, 1921.

31. Corney, W, S., Gorney, A. J. and Fomon, S., Creation of a mandibular rldge by deepening the lebial suleus and linine it with skin erart. Amer, Dent, Assn.. 29:751, 1942.

32. Sehuchhardt, K., Die Epldermistransplantation bei dex Mundvorhofplast $t k$, Deutsch ZahnaerztI, 27.364. Apri1. 1952.

33. Obwegeser, H., Surgleal preparation of the maxtlia for proathesis. I. Oral. Surg., 221127, 1964.

34. Propper, R. H., Simplifled ridge extension using free mucosal grafts, J. Oral. Surg., 22.469, 1964.

35. Coldberg. M. H., Mucosal erafts for denture preparation, J. of Conn. St. Dent. Assn., 41 i24, 1967 .

36. Sullivan and Atkins, Free autogenous gingival grafta I. Principles of aucessful grafting. Perlo., $6: 121,1968$. 
37. Clemmensen. T. Barly circulation of split skin grafts, Acta. Chir. Scand. 124.11, 1962.

38. Clemensen, T.. Early circulation of split sicin grafts. Restoration of blood supply to split skin autografta, Acta. Chlr. Scand. 12711, 1964.

39. Garglulo and Arrocha, Histoclinical evaluation of fre ginslval grafts, Perio.. 51205, 1967

40. Korman, Hublinstein, A., and Cargiulo, A., Preservation of hunan gingiva I. UI tras truetural changes and freezing teehriquos and Freservation of human gingiva II. Sequential his topathologic healing study. accepted for publication, J. of Porlo.. 1973.

41. Malaney, P. I... Shepherd, N. J., Murname, T. H., and Doku, J. C.. Free mucosal grafts for vest. fbuloplas ty, Oral. Sure, cral, hed.. Ora Path. 31.157, 1971.

42. O1lver, R., Loo, K, and Karring, T., HLroseople ovaluation of the healing and revascularization of freo ginsival grafts, J, Pexio Res., 3,84, 1968,

43. Wentscher, J., BIn terer Beltrag zux Uberlebens fahlitkeit dermenschlichen Epiderziszelien Deutsehe 2eitehr. 5 . Chir., 70:21, 1903-4

44. Carrel, Alexis, The preservation of Tissues and 1 ts applieation in surgery, J. A.邹.A., 59:523 1912.

45. Brown, J. 3, and MoDowe11, F., Skin Grafting of Burno, J. 8. Lippineott Co.. Phlladelphia, 2943. p.269.

46. Wobster, . P. Refrigerated skin grafts, Ann. Sure. $120,431,1944$. 
47. Mider, G. B. and Horton, J.J., Effect of froezing it vitro on som transplantable mamalinl turaore on normal rat skin. Amer. J, Cancen. 35.502, 1939。

48. Brisgs, R, and Jund, L., Succesaful grafting of frozen and thawed mouse skin, Anat. hec.. $89.75-84,1944$.

49. Strumia, 群, H. and Hodge, C. C., Frozen human skin grefts, Ann. Surg., 121,860, 1945.

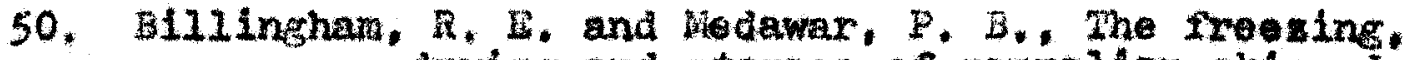
drying and storage of mamialian skin. J. of Exp. B101., 29,454, 1952 .

51. Polge, C. Snith, A, U, and Rarkes, A, S., Revival of spernatozoa after vitrifleation and dohydration at low temperatures, iature, London. $164.666,1949$.

52. Nedawar, P. B.. The storage of living skin, Proced, Roy. Soc. Hed., 47,62, 1953.

53. Smith, A. U., The use of glycerol for peservation of living celle at low temperatures, Proc Roy. S00. Med., 47:57, 1953.

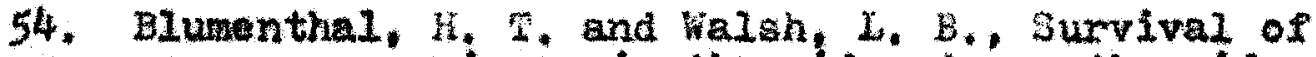
guinea pig thyrold and pare thyrold autotransplants prevlousiy subjected to extremely low temperatures, iroc, Soc. Exp. B.101., N.X. 73162, 1950.

55. Rubinstein, A., V2 trastructural changes in frozen ham topotic tissue, Abstract. XIII International Congress of liema tolosy, Munich. Germany, August, 1970 .

56. Gogsins, J, F. and Gibson, W. A., Histochemis try of viable frozenmatored human inciva, J. Invest. Derr., 51.137, 1968.

57. Brackett, R, C. and Cargtwo, A, W. Free gingival frafts in humans, $J$, of Perio., 41:581, 1970. 
58. Lovelock, J. E. Blophysical aspects of froezing and thating of living cells, Proc. Roy. Soc. hed.. 47160,1954 .

59. Iovelock, J. E.. The haemalys is of human red blood colis by troezing and thawire, wiochom., Blophys. Acta.. 10:414, 1953.

60. Neryman, 4. T., Review of slologic Freezing, In Cryoblology, Meryman, $h_{\text {. }} T$. edition, Academic Fress, Now York, pp. 1-114, 1966.

61. Dobbler, G, and Rinfret, A., Rayld froezine of human blood. Physical and chemieal considerations of injury protection. cryo., 1.205. 1965.

62. Steryman, $H$. p., Osmotic strost at a mechanism of freezine injury, cryo., 8,489, 1971.

63. Mazur, P.. Physleal factors implicated in the death of microorganisms at subzero temperatures Ann. N. Y. Acad. Sel.. 851610, 1960.

64. Steere, R. L.. Preeze-etching and direct observation of freezing danage. Cryo., 6.137, 1969.

65. Mazur, P., Kinetiog of waterlogs from cells at subzero temperatures and the likelihood of intracellular freezine.. J. Gen. Fhysiol. $47: 347,1963$.

66. Litvan, G. G., inechanism of cryoinfury in blological gys tems, cryo., 9:182, 1972 .

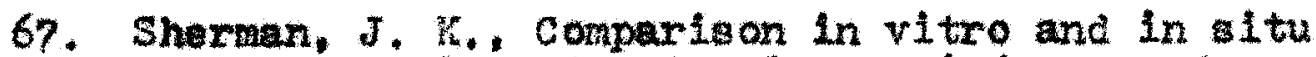
ultrestructural, oryoinjury, and cryoprotection of mitochondria, cryo., 3:112, 1972.

68. Porsidsky, M. D.. Iysosones as primary taxets of cryoinjury, Cryo., 8.482, 1971.

69. Hall, H. D. and O'Steen, A. H., Froe grafts of palatal mucosa in mandibular vestibuloplas t. J. Oral Surg... 28:565, 1970. 
70. Hazur. $Z$. The role of cell newbranes in the freezins of jeast and other singlo celle. Ann. N.Y. Aoad. Scl., 125.658, 1970.

71. Sherman, $J, x_{*}$. Fro-treatment wit proteetive substances as e factor in freezo-thaw survival. cryo*, 1.29:. 1965.

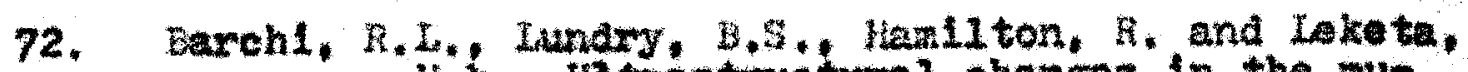
H. . . thas truc tural changes in the mucosa of trozen presarved canine lileun. cryo, 6,211, 1969 .

73. Sherman, d, k. Low temperature researeh on spermatozda and ofor. Cryo.. 11103, 1964.

74. Eondall, 0.3. and do Duve, C., Thsue fractionation studles, $x$. The ectivtion of latent dohydrogenawea in mitochondria fra rat $11 \mathrm{ver}$. Blochen, I.. 74,444, 1960.

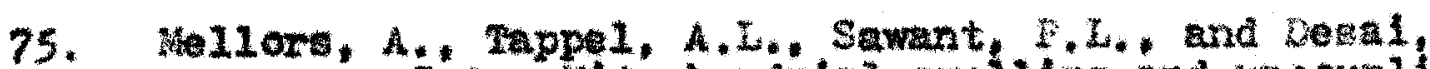

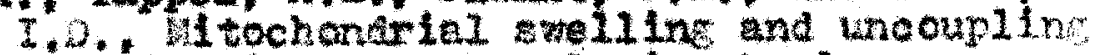
of oxldative phosphorylation by 1 yo ososes. 10chen., Jophys. Aeta. 1431299.1967.

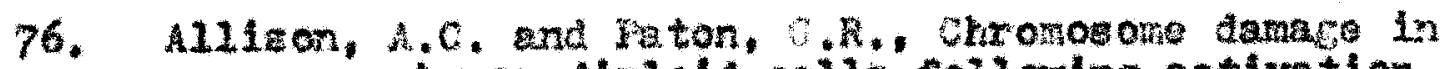
hun diplola oello follown activation

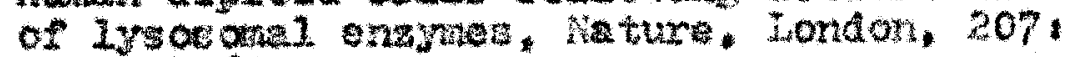
1170.1965.

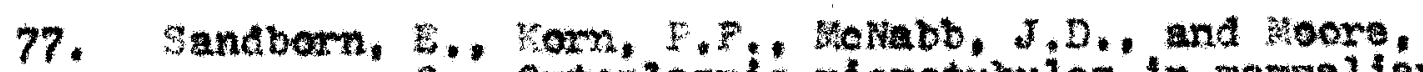
: Oytoplazme mexotubules in mamelian o.11. 


\section{AFPROVAI SHEST}

The thes is subitted by Robert A. NeInstein, D.D.S.. has been read and approved by a comittee from the Department of Oral Biology.

The Inal coples have been examined and the Ignature which appearn below veritles the fact thet any necessary changes have been ineorporated, and that the thos is is now given Itnal approval with reforence to content, form and mechanioal couracy.

The theses is, therefore, accepted in partlal tulf111ment of the requirements for the Degree of haster of selenoe
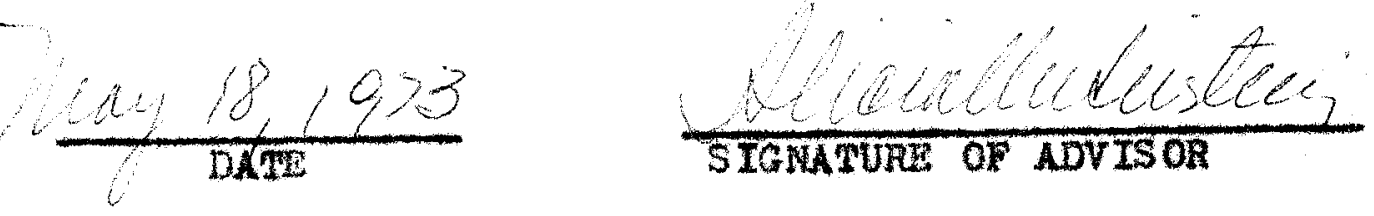